Andrews University

Digital Commons @ Andrews University

1980

\title{
A Study of the Growth of the Seventh-day Adventist Church in the Metropolitan Area of Sao Paulo, Brazil
}

Joel Sarli

Andrews University

Follow this and additional works at: https://digitalcommons.andrews.edu/dmin

Part of the Practical Theology Commons

\section{Recommended Citation}

Sarli, Joel, "A Study of the Growth of the Seventh-day Adventist Church in the Metropolitan Area of Sao Paulo, Brazil" (1980). Professional Dissertations DMin. 225.

https://dx.doi.org/10.32597/dmin/225

https://digitalcommons.andrews.edu/dmin/225

This Project Report is brought to you for free and open access by the Graduate Research at Digital Commons @ Andrews University. It has been accepted for inclusion in Professional Dissertations DMin by an authorized administrator of Digital Commons @ Andrews University. For more information, please contact repository@andrews.edu. 


\section{ABSTRACT}

A STUDY OF THE GROWTH OF THE SEVENTH-DAY ADVENTIST CHURCH IN THE METROPOLITAN AREA OF SAO PAULO, BRAZIL

by

Joel Sarli

Chairman: Werner Vyhmeister 


\title{
ABSTRACT OF GRADUATE STUDENT RESEARCH \\ Project-Dissertation
}

\author{
Andrews University
}

Seventh-day Adventist Theological Seminary

Title: A STUDY OF THE GROWTH OF THE SEVENTH-DAY ADVENTIST CHURCH IN THE METROPOLITAN AREA OF SAO PAULO, BRAZIL Name of researcher: Joel Sarli Name and title of faculty adviser: Werner Vyhmeister, Ph.D. Date completed: December 1980

\section{Problem}

Over seventy-two years have passed since the first Adventist church was organized in the metropolitan area of Sao Paulo, Brazil. During those years the church leadership has noted that the rate of Adventist Church growth there has been one of the highest in the world. In spite of this unique phenomenon of growth, no serious research has been undertaken to determine what the factors are that have helped the people to make their decision to accept the Adventist message. An evaluation of the Seventh-day Adventist outreach during the last five years $(1975-1979)$ is necessary to determine which methods should be emulated to give a higher growth rate to the Church in future. 
Method

The method used for this study lead into three different areas: (1) a brief historical, sociological, and theological reflection on the meaning of the SDA Church of Sao Paulo in relationship to the city itself and to the Adventist Church in general; (2) a collection of data by means of a questionnaire administered to the members converted during the past five years; and (3) the organization of the data into tables giving frequences and percentages. In order to give some recommendations in relationship to the effectiveness of certain outreach methods in the area, the data were analyzed and conclusions were drawn.

\section{Results}

The final results of the research were related to the main objective of the study. Most of the new converts received their first information about the Adventist Church through friends and family members. The greatest personal influence on the new members' decisions to join the Adventists was lay activities. The preaching of the law and obedience to the Ten Commandments caught the attention of the majority of new converts and some of them have a legalistic view of some Adventist doctrines, according to the answers given on the questionnaire. Lastly, the social forces of the SDA Church helped the new converts to find a new community to replace the rural or small-village communities they left when they migrated to the city. 
3

\section{Conclusions}

Some of the conclusions of the study are: (1) the SDA Church in Sao Paulo must use all the resources of the lay activities to reach the people; (2) the Adventists have to preach a more Christ-centered message in Sao Paulo; (3) the Church should use social elements to win the different social groups that make up the Paulistan community. 
Andrews University

Seventh-day Adventist Theological Seminary

\title{
A STUDY OF THE GROWTH OF THE SEVENTH-DAY ADVENTIST CHURCH IN THE METROPOLITAN AREA OF SAO PAULO, BRAZIL
}

\author{
A Project-Dissertation \\ Presented in Partial Fulfillment \\ of the Requirements for the Degree \\ Doctor of Ministry
}

\section{by}

Joel Sarli

December 1980 



\title{
A STUDY OF THE GROWTH OF THE SEVENTH-DAY ADVENTIST CHURCH IN THE METROPOLITAN \\ AREA OF SAO PAULO, BRAZIL
}

\author{
A project-dissertation \\ presented in partial fulfillment \\ of the requirements for the degree \\ Doctor of Ministry
}

by

Joel Sarli

APPROVAL BY THE COMMITTEE:

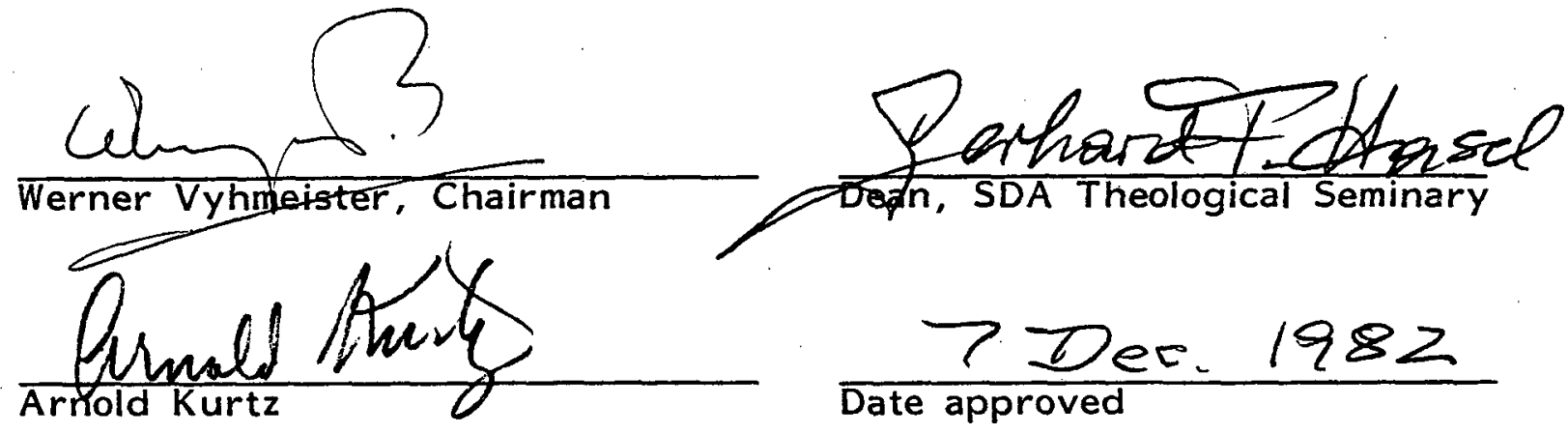

Elence A. Qrampos

Eduardo Ocampo 
LIST OF FIGURES .................

LIST OF TABLES ........................ vii

ACKNOWLEDGEMENTS .................... ix

Chapter

I. INTRODUCTION ...................... 1

The Need for the Study . . . . . . . . . 1

Objectives ................ . . . 10

Limitations of the Study ............ 11

Description of the Project. . . . . . . . . 12

Definition of Terms............. 16

Overview of the Study .......... 17

II. THE URBAN MISSION OF THE SDA CHURCH

IN GREATER SAO PAULO ........... 19

Motivation for Church Mission . . . . . . . . 21

The Peculiar Mission of the SDA Church .....

III. SAO PAULO, ITS HISTORY AND PEOPLE . . . . . 28

Historical Background .... . . . . . . . 28

The Immigrants and the New Era ......... 29

The Challenge of Social Structure... . . . . 31

IV. THE RELIGIOUS PANORAMA OF SAO PAULO

TODAY :............... 41

Roman Catholicism ........... . . 41

The Evangelical Churches............ 43

Non-Christian Religions........... . 45

The SDA Church in Sao Paulo.......... 50

Conclusion ............... 61

V. ANALYSIS OF THE CHURCH GROWTH FINDINGS

OF THE SEVENTH-DAY ADVENTIST CHURCH

IN SAO PAULO .......................... 63

Introduction .................... 63

Sociological Factors and Church Growth...... 64 
Religious Factors and Church Growth . . . . . . . 75

The Outreach Strategy and Church Growth . . . . . 79

Conclusion . . . . . . . . . . . . . . . 88

V1. SUMMARY, CONCLUSIONS, AND RECOMMEND-

DATIONS .................... 90

Summary .. . . . . . . . . . . . . . 90

Conclusions and Recommendations . . . . . . . 93

Recommendations for Further Study . . . . . . . 112

General Conclusion ............. 113

APPENDIX A . . . . . . . . . . . . . . . . 115

APPENDIX B ............................ 122

BIBLIOGRAPHY . . . . . . . . . . . . . . . . 124

VITA ......................... 133 


\section{LIST OF FIGURES}

1. Micro-region 262 in the state of Sao Paulo . . . . . . 5

2. Demographic density of different areas in Brazil ..... 40

3. Above--Total population divided into Evangelical and Catholic groups featuring the penetration of the nonChristian religion into Catholicism.

Below--Non-Catholic religions including Spiritism and

Umbanda .................

4. A male and female comparison of the total sample of new converts .............. 66

5. Comparison of age distribution by male and female . . . 68

6. Comparison of monthly income of the new members by male and female ............. 73

7. Brazil--Geographical Regions . . . . . . . . . 76

8. Sao Paulo State--East Micro-Regions . . . . . . . 123 


\section{LIST OF TABLES}

1. Comparative Growth Study of the SDA Church in Three Metropolitan Areas . . . . . . . . . . .

2. Economic and Size Stratification of Sao Paulo Churches . . . . . . . . . . . . . . .

3. Stratification According to Adventist Social Context Typology of the Sao Paulo Area . . . . . . . . . .

4. Catholics in Greater Sao Paulo Today . . . . . . . . .

5. The Work Force, Unemployment and Inactivity by

Sex and Age in Greater Sao Paulo in 1972 . . . . . .

6. Municipality of Sao Paulo: Nutrition Levels for Working Population by Family Income (1969-70) . . . . .

7. Greater Sao Paulo Average Number of Residents per Bedroom (1970).................. 36

8. SDA Church Growth Comparative by Age . . . . . . . 60

9. Comparison of Population Growth with SDA Church Growth: 1970-1979 ...............

10. Age of the New Converts (1975-1979) . . . . . . .

11. Marital Status of the New Converts . . . . . . . .

12. Formal Education of the New Converts. . . . . . . . 70

13. Occupational Status of the New Converts . . . . . . . 71

14. Monthly Income of the New Converts . . . . . . . . 72

15. Community Size from Which the New Converts Migrated to Sao Paulo... . . . . . . . . . . 74

16. Geographical Region of Origin of the New Converts . . . 74

17. The Influence of Previous Religion in the Life of the New Converts ................... 
18. Previous Religious Non-SDA Affiliation .......

19. Source from Which the New Convert First Received Information about the SDA Church ..........

20. Source from Which the New Male Converts First Received Information about the SDA Church .....

21. Source from Which New Female Converts First Received Information about the SDA Church ......

22. The Most Influential Factor in the Decision to Join the SDA Church ..................

23. The Most Influential Factor for Protestants to Join the SDA Church ....................

24. The Most Influential Factor for Catholics to Join the SDA Church ..................

25. Outreach Agencies that Helped More New Converts to Join the SDA Church .. . . . . . . . . .

26. Radio, Television, and Telephone and Their Influence in Bringing New Members to the SDA. Church . . . .

27. Adventist Magazines and Newspapers and Their Percentage of Influence on New Converts . . . . . . .

28. Bible Study Methods that Most Helped New Converts Make Decisions . . . . . . . . . . . . . .

29. Reasons that Led the New Converts to Join the SDA Church .....................

30. The Most Attractive Element in the SDA Community for the New Converts . . . . . . . . . . . . . . 


\section{ACKNOWLEDGEMENTS}

Many people have contributed to the completion of this study. To acknowledge my sincere gratitude to all who have made the completion of this research possible is not mere submission to an academic tradition or the accomplishment of a conventional social obligation. It is, rather, a privilege and a pleasure to mention here my indebtedness to them and to express my gratitude.

I want to express my deep appreciation to the members of my committee who have been most cooperative, supportive, and helpful throughout the stages of this study: Dr. Werner K. Vyhmeister for his professional guidance and insights into the area of church growth in Sao Paulo, Dr. Arnold Kurtz, and Dr. Eduardo Ocampo.

Margarida, my loving and self-sacrificing wife, deserves my most unreserved gratitude. Through my graduate study she gave full support and especially during the last five months of 1980 she remained in Brazil taking care of all the family affairs, thus making it possible for me to write this project-dissertation. I wish to express my deep appreciation for her kind understanding and support, and to her 1 dedicate this project-dissertation.

Beyond all human help received, the constant care and guidance of a loving God is fully acknowledged. I am indeed thankful to Him for the total learning and enriching experience during the years spent at Andrews University at the feet of good Christian teachers, and for 
the health enjoyed throughout the entire course of study. To God be all the praise. 


\section{CHAPTER I}

\section{INTRODUCTION}

Always the growth or decline of any religious denomination is related to internal and external factors. They may be unknown but they exist and play a decisive role in the developing process of the entity. If determined and emulated they can be very helpful to those in charge of the final task of the church. This research is a study of the growth of the Seventh-day Adventist Church in the metropolitan area of Sao Paulo, Brazil, and it intends to determine which factors influence people to accept or reject Adventism, and on that basis to suggest an evangelistic strategy for further increasing church growth in that urban area ( see appendix $C$, figure 8).

\section{The Need for the Study}

Growth, Wilburn Thomas says, is a test of faithfulness of any church. ${ }^{1}$ The Seventh-day Adventist Church understands that the effectiveness of the mission of God's people cannot be determined simply by its institutional strength, organizational structure, financial resources, and universal presence in the world. 2

${ }^{1}$ Thomas $\mathrm{J}$. Ligget, The Role of the Missionary in Latin America Today (New York: Committee on Cooperation in Latin America, NCCC, 1963), p. 11.

${ }^{2}$ Gottfried Oosterwal, "The Seventh-day Adventist Church in the World Today," Servants for Christ: The Adventist Church Facing 
Any living, healthy organism must grow as part of its own natural development, according to the words of the apostle Paul in Eph $4: 16$. But the growth must be harmonious and symmetrical in all aspects. However, for the particular purpose of this study, research will be limited to numerical growth of the Seventh-day Adventist Church in Greater Sao Paulo, Brazil.

Over seventy-two years have passed since the first Adventist church was organized in the metropolitan area of Sao Paulo. ${ }^{1}$ During those years the attention of the Church leadership has been called to the fact that the growth rate of Adventists in Sao Paulo has been one of the highest in the world. In spite of this unique phenomenon of growth, no serious research has been undertaken to determine the factors that have helped people to make their decision to accept the Advent message.

It is my conviction that in the past seventy years the Seventhday Adventist Church in Sao Paulo has lost many opportunities to develop an adequate outreach strategy to take advantage of the responsive population living in the special social setting, as far as its mission task is concerned. This conviction is based on observations made when comparing the work of the Seventh-day Adventist Church with other denominations, mainly the Christian Congregation in Brazil. Both, the Adventist Church and the Christian Congregation, had their start in Sao Paulo by 1910 . Today, the Christian Congregation

the $80^{\prime} s$, ed. Robert E. Firth (Berrien Springs, Mich.: Andrews University Press, 1980), p. 3. p. 2 .

${ }^{1}$ Emilio Hoelzle, "Missao Paulista," Revista Mensal (January 1908), 
in Brazil has about 120,000 members. In 1978, according to the last statistical report available, they baptized 8,133 people in the Sao Paulo area. ${ }^{1}$ At the same time the Seventh-day Adventist Church baptized about 4,000 in 1978 and presently has 35,000 members. $^{2}$ More comparisons could be made, but these are enough to indicate a need for a serious research to determine the strengths and weaknesses of the different areas of activity of the Adventist Church of Sao Paulo.

There are at least three reasons for the importance of this study if Adventists are to take their responsibility for proclaiming the eternal gospel seriously.

1. The first reason considers the importance of the city itself. Sao Paulo is different from all other cities. To begin with, while most urban centers located in the tropics have fewer than three million inhabitants, Sao Paulo shelters more than thirteen million people and realizes a population growth of half a million each year.

Furthermore, few cities have the concentration of economic power that is as meaningful to the entire country as does Sao Paulo in relationship to Brazil. Almost one-third of all Brazilian industries and about one-half of the country's industrial workers are located in that one city. About 30 percent of the national income flows through its three thousand banks.

Thanks to its thirteen million residents, ${ }^{3}$ Sao Paulo is the

${ }^{1}$ Relatório Estatístico da Congregação Cristã do Brasil (Sao Paulo: Congregação Cristẫ do Brasil, 1978).

${ }^{2}$ Relatório Estatístico da Associaçăo Paulista Leste (Sao Paulo: East Sao Paulo Conference of Seventh-day Adventists, 1979), p. 7.

${ }^{3}$ O Guia de Sao Paulo (Sao Paulo: Quatro Rodas, 1980), p. 43. 
largest city in South America and the fifth largest in the world. It is Brazil's leading industrial center with 50 percent of the country's overall production. It has five hundred hotels, 170 cinemas, and 6 TV channels. Twelve major daily newspapers and over 200 smaller newspapers and periodicals keep the people informed. Over two million volumes are housed in 146 libraries.

This metropolitan area is a major transportation center: three railroads, five main highways, and two airports connect all local travel within the country and with the world. These services are growing constantly to meet the needs of the 7 percent of the entire Brazilian population which lives in Sao Paulo--a city with a density of about six thousand inhabitants per square kilometer. 'Every day a thousand new inhabitants are born, and plans for decentralization are underway for the population of twenty million expected by the year 2000 .

In 1967 Greater Sao Paulo was officially made into a metropolitan region and placed within the boundaries of a new homogeneous microregion under the number 262 . This micro-region has thirty-eight counties grouped around the urban core. The five largest counties-Guarulhos, Osasco, Santo Andre, Sao Bernardo, and Sao Caetano--form with Sao Paulo a continuous urban concentration whose streets converge in the downtown section ( see figure 1).

According to Howard A. Snyder, former dean of the Free Methodist Theological Seminary ${ }^{2}$ in Sao Paulo, Brazil is a crucial country

${ }^{1}$ Leonardo Arroyo, Sao Paulo (Rio de Janeiro: Livraria Kosmos Editora, 1979), p. 4.

${ }^{2}$ Roger S. Greenway, Guidelines for Urban Church Planting (Grand Rapids: Baker, 1978), p. 21. 


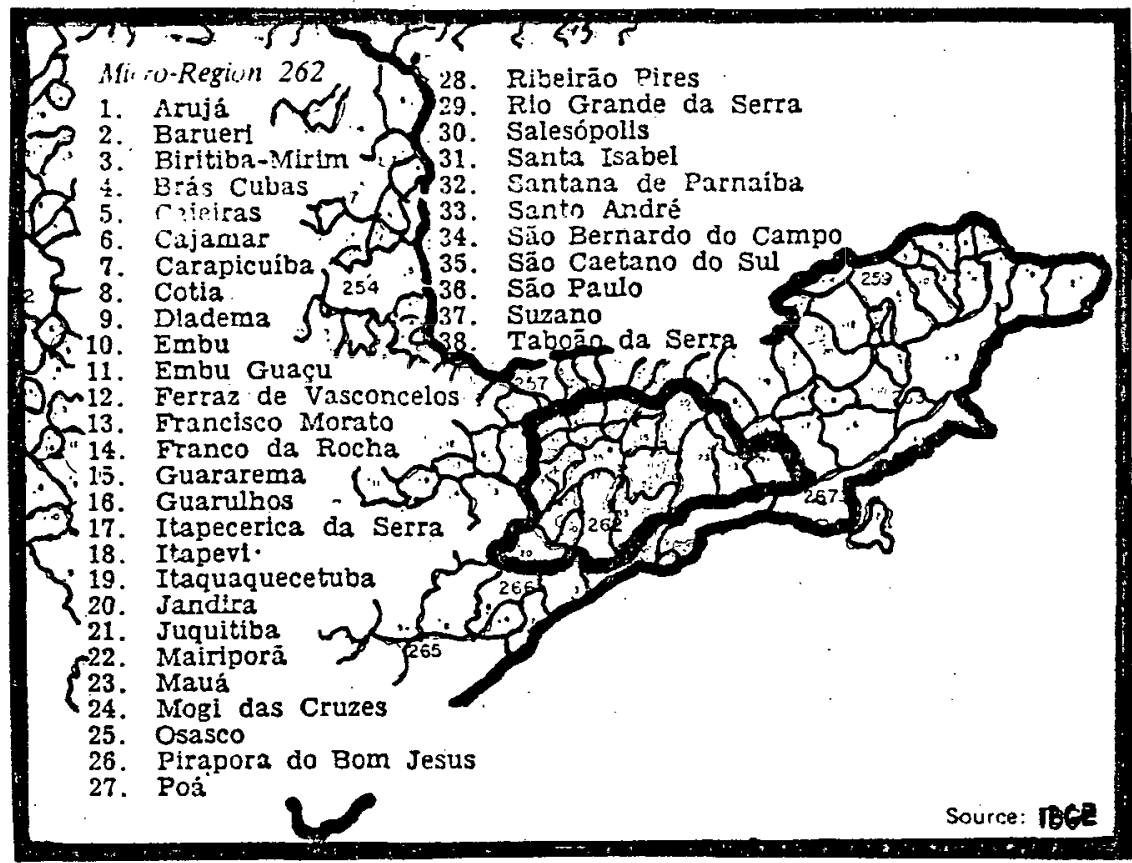

Figure 1. Micro-region 262 in the state of Sao Paulo in 1980.

for the future of the Church of Jesus Christ, and possibly for the future of the world. Taking into account the important role the metropolitan area of Sao Paulo plays in all Brazilian affairs, it is easy to understand how it constitutes a decisive factor not only in political or economical activities but can also be applied to the action of the church in propagating the gospel of Jesus, the Lord and Saviour.

2. A second reason for the importance of this study has to do with the present activity of many religious groups in the Sao Paulo area.

Sao Paulo is now an intense spiritual battleground contested by three main forces. First, there is Spiritualism which, in its varied forms, continues to grow rapidly. Second, there is materialism and the forces of secularization. And third, there is the Christian faith whose most 
significant appeal today is through Pentecostalism, the more traditional Protestant mission and churches, and, to some extent, the renewal movement within the Catholic Church ${ }^{1}$ which is now under the influence of liberation theology.

Emilio Willems, of Vanderbilt University, has made a thoughtful and revealing study of the rise of Protestantism in Brazil and Chile in his book Followers of the New Faith. His thesis is that Protestantism had its antecedents, if not its roots, in structural peculiarities of the traditional Brazilian and Chilean societies. During his course of study, Willems found that Protestantism was statistically stronger in industrialized and frontier areas. His research in Brazil was made both in the capital city of Sao Paulo and in the state as well. ${ }^{2}$

The Sao Paulo area is not only the unquestioned leader in industrial production in Brazil it also has the largest concentration of Protestants. According to Willems' report, 58.1 percent of the Protestants are found in the industrial zone which includes the capital city of Sao Paulo and the surrounding satellite cities. ${ }^{3}$ MARC Church Growth Data Bank reports that the increase of Protestant communicant membership from 1955-1966 in Sao Paulo represented a 145.8 percent gain in the twelve-year period. ${ }^{4}$ The projection of Protestant growth in the

${ }^{1}$ William R. Read, New Patterns of Church Growth in Brazil (Grand Rapids: Eerdmans, 1965), pp. 7-17.

${ }^{2}$ C. W. Gates, Industrialization: Brazil's Catalyst for Church Growth (South Pasadena, Calif.: William Carey Library, 1972), p. 3.

${ }^{3}$ Emilio Willems, Followers of the New Faith (Nashville, Tenn.: Vanderbilt University Press, 1967), p. 69.

${ }^{4}$ Gates, p. 59. 
metropolitan area, based on the yearly average of 8.4 percent, gives micro-region 262 an estimated one million communicants in 1980.

There are indications that where people are ready to accept the message preached by other denominations they are ready to accept the Adventist message as well.

It is my personal belief that the strategy followed by other denominations can give useful clues to the Adventist evangelistic planning for the future.

3. The growth of the Seventh-day Adventist Church itself constitutes the third important reason for undertaking this study. Presently Adventists in the metropolitan area of Sao Paulo have 85 churches and 122 companies with a total of 35,000 church members. ${ }^{1}$ If these figures are compared with those found in other metropolitan areas around the world it is easy to see the uniqueness of the growth of Seventh-day Adventism in Sao Paulo.

For example, the SDA Church in Greater New York Conference had its beginning in 1851 with the organization of a church of 13 members. In 1979 there were in that metropolitan area 54 churches with a total of 7,121 members. This gives a yearly average growth of 55 members. The first Adventist church in the Southern California Conference area was organized in 1884 in San Pasqual. In 1979 there were 116 churches with a total of 34,823 baptized members, a yearly average growth of 374 members. Now when this information is compared with Adventist growth in the Sao Paulo area the following facts

\footnotetext{
${ }^{1}$ Seventh-day Adventist Yearbook (Washington, D.C.: Review and Herald, 1980), pp. 40, 88, 270.
} 
are noted. The first church organized in East Sao Paulo Conference was in Sao Bernardo do Campos with fourteen baptized members. In 1979 in the area there were 44,271 members, a yearly average growth of 614 members $^{1}$ (see table 1 ).

TABLE 1

COMPARATIVE GROWTH STUDY OF THE SDA CHURCH IN THREE METROPOLITAN AREAS

\begin{tabular}{|c|c|c|c|c|c|c|c|}
\hline $\begin{array}{l}\text { Conferences } \\
\text { Including } \\
\text { Metropolitan. } \\
\text { Areas of: }\end{array}$ & 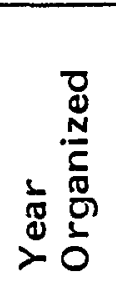 & 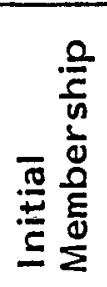 & 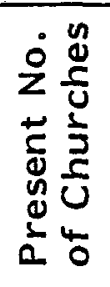 & 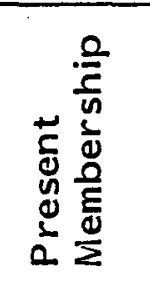 & 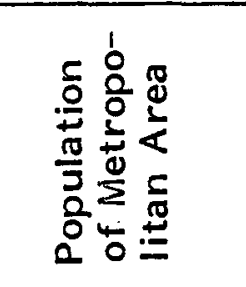 & $\begin{array}{l}\frac{5}{2} \\
\frac{\pi}{3} \\
\frac{\pi}{3} \\
2 \\
20\end{array}$ & 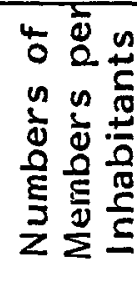 \\
\hline New York & 1851 & 13 & 54 & 7,121 & $12,354,864$ & 55 & 1740 \\
\hline Los Angeles & 1884 & 14 & 116 & 34,823 & $8,080,800$ & 374 & 250 \\
\hline Sao Paulo & 1908 & 14 & 152 & 44,271 & $13,075,433$ & 614 & 300 \\
\hline
\end{tabular}

This comparison indicates that there is something unique in Sao Paulo or in the work of the SDA Church here that should be investigated. The Church should know which methods should be emulated and which should be avoided when developing an evangelistic strategy for the future.

How does the SDA Church leadership plan for church growth for 1985, 1990, and beyond in an area of such restless migration, urbanization, and modernization? What are the forces that shape urban

'Don F. Neufeld, ed., Seventh-day Adventist Encyclopedia (Washington, D.C.: Review and Herald Publishing Association, 1976), s.v. "Brazil," "Greater New York Conference," "Southern California Conference." 
culture? What are the prevailing moods, needs, and values? How can the gospel best get a hearing? How much is evangelism's strategy determined by the questions people are asking? What is the configuration of the good news in a society that is increasingly urbanized, secularized, and paganized? How can the Church help citizens come to grips with their personal alienation from God and their fractured relationship with others? What can be done for the vast number who feel no overwhelming need for God or for change? How does the SDA Church communicate the exclusiveness of Christ's claim as "The Way, the Truth and the Life" and His soon return in an increasingly pluralistic culture?

These and other questions are basic to the formulation of an urban evangelization strategy if the SDA Church is to be effective in fulfilling its mission. It is true that the Adventist Church cannot deal with all these questions at the same time, but as a responsible Church, its leaders should be aware of the real issues when developing the evangelistic program for the years to come.

Sao Paulo is a critical area that requires immediately this kind of church-growth research, and such a study cannot be made without the involvement of the whole church.

The situation found in Sao Paulo and in similar metropolitan areas calls for a search for new insights into the working of God in history and a fresh approach to the mission of the Church as it stands amid the currents of today. The Church must be a witness pointing to the mighty works of God as He holds the destiny of the whole world in 
His hand and works out His purposes in history. ${ }^{1}$ It was the awareness of this mission of the entire Adventist Church and a cognizance of the need for a greater evangelistic structuring in fast-growing metropolitan areas, such as Sao Paulo, that led to this project.

\section{Objectives}

The purpose of this research, then, is to discover and evaluate the factors that influenced SDA church growth in Sao Paulo during the last five years (1975-1979) so that the Church might more effectively administer its resources in developing a program for growth. The specific objectives of this project are:

1. To prepare a brief historical and sociological description of Sao Paulo and to reflect theologically on the action of the Seventh-day Adventist Church in the field of urban church growth

2. To develop a survey instrument that may identify factors or methods that have influenced people to accept the Seventh-day Adventist message

3. To give the SDA Church in Sao Paulo an opportunity to evaluate its present outreach strategy

4. To identify elements necessary for the development of an adequate, harmonious, urban evangelistic program

5. To make recommendations as to how the SDA Church could allocate available human and material resources to its local churches in order to achieve best results.

${ }^{1}$ Ligget, p. 88. 
Limitations of the Study

In current church growth literature authorities recognize four different kinds of growth: (1) Numerical growth that is the perpetual ingathering of new disciples of Jesus Christ into the fellowship of local congregations or the gathering of new believers into new churches; (2) organic growth that has to do with the development of the church or a community. It concerns the internal structure of relationships within the body itself. As an example of that growth it is presented the choice of the seven in Acts 6:1-7, and the sending out of Barnabas and Saul to Antioch in Acts $13: 1-13$; (3) maturational growth that refers to the movement toward perfection and maturity, that is to say, the spiritual development of church members; (4) incarnational growth that is defined as the expansion of the church which is seen by its effects on its environment. 1

In this study, the concept of church growth is limited to numerical growth with particular attention given to membership increase through conversion in Sao Paulo metropolitan area in the last five years (1975-1979). The research was conducted only among new converts who received the Adventist message, who are now attending churches, and who were not reared in Adventist homes prior to age 15.

Reference is made to organic, maturational, and incarnational growth only as they relate to the promotion or hindrance of total membership growth.

${ }^{1}$ Charles L. Chaney and Ron S. Lewis, Design for Church Growth (Nashville, Tenn.: Broadman Press, 1977), pp. 17-18. 


\section{Description of the Project}

I was born in Sao Paulo and spent most of my ministry working in different areas of the Adventist Church in that city. Presently 1 teach public evangelism in the Adventist School of Theology in Sao Paulo.

Having been associated with and worked among Paulistanos, 1 am personally aware of the practices and way of life of most of the Sao Paulo churches. Most of the pastors of the churches in which the research was done studied in Brazil College and are my personal acquaintances. These factors have greatly facilitated gathering the necessary data and have also provided a better understanding of the feelings both of minister and laity regarding positive and negative factors which may have stimulated or hindered church growth.

Treasurers and clerks in the churches, in conjunction with their pastors, provided complete written statistical reports indicating the economic level of the churches, the number of baptized members, and the number of those who were added to the church in the past five years (1975-1979).

Stratification, done according to the consensus of the leadership of the East Sao Paulo Conference, was as follows:

1. The first factor was the size of the churches: (a) small churches--50 to 150 members; (b) middle-sized churches--151 to 350 members; and (c) large churches--351 or more members.

2. The second factor was the amount of tithe in the last tenmonth period of 1979; (a) class A--churches with a tithe average higher than US $\$ 500.00$; (b) class $B--$ churches with a tithe average from 
US $\$ 499.00$ to US $\$ 200.00$; and (c). class C--churches with a tithe average below US $\$ 199.00$ per member.

These two stratification categories are shown in table 2.

TABLE 2

ECONOMIC AND SIZE STRATIFICATION

OF SAO PAULO CHURCHES

\begin{tabular}{|c|c|c|c|}
\hline Class & Large Churches & Middle-sized Churches & Small Churches \\
\hline$A$ & $\begin{array}{l}\text { Santo Andre } \\
\text { Belem } \\
\text { Pinheiros } \\
\text { I.A.F. } \\
\text { Brooklin } \\
\text { Central }\end{array}$ & & \\
\hline B & Capao Redonda & $\begin{array}{l}\text { Osasco } \\
\text { Vila Maria } \\
\text { Alvorada } \\
\text { Santo Amaro } \\
\text { Guarulhos } \\
\text { Penha } \\
\text { Vila Carrao } \\
\text { Campo de Fora } \\
\text { Mogi das Cruzes } \\
\text { Bosque da Saude }\end{array}$ & \\
\hline C & & Jardim das Palmeiras & $\begin{array}{l}\text { J. Maringa } \\
\text { Embu } \\
\text { V. Alpina } \\
\text { Sapobemba } \\
\text { Diadema } \\
\text { J. Margarida } \\
\text { Vila Re } \\
\text { Guainazes } \\
\text { V. Munhoz } \\
\text { V. Industrial } \\
\text { Grajau } \\
\text { Campo Limpo } \\
\text { Agua Raza } \\
\text { V. Guarani } \\
\text { Itapecirica }\end{array}$ \\
\hline
\end{tabular}


Table 2 Continued

Class Large Churches Middle-sized Churches Small Churches

J. Rosas

Valo Velho

Sto Eduardo

J. Kennedy

V. Ferreira

J. Sao Luiz

C. Sto Antonio

J. Sao Bernardo

Cruzeiro

J. Lilah

TOTAL

\begin{tabular}{|c|c|c|c|}
\hline Class & Churches & Members & Questionnaires Answered \\
\hline $\begin{array}{l}\text { Class A } \\
\text { Class B } \\
\text { Class } C\end{array}$ & $\begin{array}{r}6 \\
11 \\
26\end{array}$ & $\begin{array}{l}2,550 \\
3,050 \\
4,250\end{array}$ & $\begin{array}{l}208 \\
213 \\
269\end{array}$ \\
\hline Total & 43 & 9,850 & 693 \\
\hline
\end{tabular}

3. The third factor used in the stratification of the Sao Paulo metropolitan area was based on the concept presented by Douglas A. Walrath in the book Understanding Church Growth and Decline 1950-1978.' He points out that within the metropolitan region there are three subgroups--city area, suburbs, and fringe areas. Therefore a selection of respondents was made to include people from churches located in (a) city areas, (b) the suburban regions, and (c) urban fringe areas

${ }^{1}$ Douglas W. Walrath, "Social Change and Local Churches: 195175," Understanding Church Growth and Decline 1950-1978, ed. by Dean R. Hoge and David A. Roozen (New York: Pilgrim, 1979), p. 252. 
with an adequate number of churches proportionate to the total number of members in each category.

TABLE 3

STRATIFICATION ACCORDING TO ADVENTIST SOCIAL-CONTEXT TYPOLOGY OF THE SAO PAULO AREA

\begin{tabular}{lcc}
\hline \hline Type of Area & Percentage of Members & $\begin{array}{c}\text { Number of Churches } \\
\text { and Companies }\end{array}$ \\
\hline City Area & 10 & 8 \\
Suburban area & 30 & 26 \\
Urban fringe & 60 & 166 \\
\hline Total & 100 & 200 \\
\hline
\end{tabular}

According to the consensus of the East Sao Paulo Conference administration the proportion of the total number in each category is: (a) in the urban fringe area are located most of the small churches with about 60 percent of the membership; (b) in the suburban region are almost all the middle-sized churches with about 30 percent of the membership; and (c) in the city area are the large churches with about 10 percent of the members. There is an interrelation between the city area and the suburban region as well as with the urban fringe but not significant enough to deserve a special category.

On a Sabbath morning, during the regular worship hour, a special meeting was held in a separate room for those converted in the past five years. Questionnaires were administered by students of the Adventist School of Theology who were especially trained by the researcher for this purpose. 
In the final stages of this investigation, survey data obtained from the questionnaires were sorted and tabulated by the computer facilities of Andrews University. These findings were then evaluated, analyzed, and interpreted. Conclusions were drawn and from them recommendations made.

\section{Definition of Terms}

Adventist. A shortened form for Seventh-day Adventist

Adventist Message. The fundamental Seventh-day Adventist beliefs as they appear in the Seventh-day Adventist Yearbook. ${ }^{1}$

Church. The multi-level, formally organized governing bodies of the Seventh-day Adventist Church, which include churches, local conferences and missions, union conference, and general conference.

church. A local congregation of laypersons who vote the new convert into membership.

Church leadership. Those who are administrators of the resources of the Church.

East Sao Paulo Conference. An organization of 132 churches located in the capital and littoral of Sao Paulo State. ${ }^{2}$

Member. One who is fully accepted as part of a local congregation, according to the requirements of the Seventh-dayAdventist Church Manual. 3

${ }^{1}$ Seventh-day Adventist Year'oook (1980), pp. 5-6.

2 Ibid., p. 270.

${ }^{3}$ Seventh-day Adventist Church Manual (Washington D.C.: General Conference of the Seventh-day Adventists, 1976), pp. 50-74. 
Nordestino. A Brazilian who was born in the states of the Northeast of Brazil.

Pastor. The administrative and spiritual leader of a local congregation, who is ordained for such work. ${ }^{1}$

Paulista. One who was born in Sao Paulo state.

Paulistano. One who was born in Sao Paulo city.

SDA. An abbreviation for Seventh-day Adventist.

Sao Paulo. The micro-region number 262 established in 1967 by a Brazilian Law, which is formed of 38 counties grouped around the core of Sao Paulo city itself. ${ }^{2}$

Spiritism. The term Spiritism, rather than Spiritualism, will be used to denote the new religious quality related to the special spiritualistic groups operating in Sao Paulo city.

Umbanda. A syncretic spiritualistic Afro-Brazilian religion developed in Brazil.

\section{Overview of the Study}

The study is divided into the following chapteris:

Chapter I deals with the need of the study, states the objectives; gives a brief description of it, and defines terms used.

Chapter II provides a basis for understanding the theology upon which the SDA Church has developed its program of urban missionary expansion.

${ }^{1}$ Manual for Ministers (Washington, D.C.: General Conference of Seventh-day Adventists, 1977), pp. 15-32.

${ }^{2}$ Read and Ineson, Brazil: 1980 (Monrovia, Calif.: A Division of World Vision In ternational, 1973), pp. 153, 159. 
Chapter III presents the historical and sociological background of the metropolitan area of Sao Paulo where the SDA Church has established about 200 congregations.

Chapter IV describes the main religious groups that are found in Sao Paulo as of 1980, and features the SDA Church in particular.

Chapter $\mathrm{V}$ analyzes the growth of the SDA Church during the past five years. Its objective is to determine how initial contact with Adventists was made and what influenced the new converts most to join the SDA Church.

Chapter VI contains the summary, the basis for conclusions, recommendations, and implications. 


\section{CHAPTER II}

\section{THE URBAN MISSION OF THE SDA CHURCH \\ IN GREATER SAO PAULO}

\section{Urbanization}

It is impossible to study the mission of the SDA Church in Sao Paulo metropolitan area without understanding urbanization and without recognizing other forces that are at work within the whole society of the city.

There are many definitions of urbanization. However, for the purposes of this research it is enough to say that urbanization is the concentration of an increasing proportion of a given population in a small geographical area. In fact, much of the population of the world is rapidly becoming urbanized, both in terms of the total population concentrated in urban places and in the growing number of urban areas. $^{1}$

Now if attention is focused on Brazil, the largest country of South America and its explosive population of 140 million, it is easy to recognize that the greatest urban center of Brazil is the metropolitan area of Sao Paulo.

A recent statistical report (1980) shows that the urbanization

${ }^{1}$ Gottfried Oosterwal, "How Shall We Work the Cities from Within?" Ministry (June 1980), pp. 19, 20. 
rate in Creater Sao Paulo is 97.66 percent and the demographic density is $5,460.80$ inhabitants per square kilometer. ${ }^{1}$ One official report on the city's Basic Urban Plan notes that in less than three decades the population of the municipality of Sao Paulo quadrupled, going from 1.3 million in 1940 to 5.8 million in 1969. In Greater Sao Paulo, during the same period the population grew from 1.6 million to 7.9 million. This phenomenal growth is explained, in a large measure, by the intense pace of economic development in the area, and--due to the rising increase of incomes--the heavy internal migration to this region. ${ }^{2}$

The rapid growth of the Sao Paulo metropolitan area presents many parallels in both population and church growth. According to Read and Ineson a high percentage of the Protestant communicants in Brazil is concentrated in the Sao Paulo industrial area, ${ }^{3}$ and the growth of the Evangelical Churches, mainly the Pentecostal churches, is higher there than in any other part of the country.

In the book Industrialization: Brazil's Catalyst for Church Growth, Charles Gates points out that the internal migration in Sao Paulo is a rural-urban migration. ${ }^{4}$ Herold Wesley Melvin, Jr., adds that religion plays a very important role in the integrative process of the migrants in the urban area of Sao Paulo. ${ }^{5}$ It seems that there are many factors

1 SEAD. Central de Dados e Referencias do Governo do Estado de Sao Paulo (Sao Paulo: Secretaria do Planejamento, 1980).

${ }^{2}$ Greenway, Urban Church Planting, pp. 21, 22.

${ }^{3}$ Read and Ineson; p. 49.

${ }^{4}$ Gates, p. 19.

${ }^{5}$ Herold Wesley Melvin, Jr., "Religion in Brazil: A Sociological Approach to Religion," Th.D. Dissertation (Boston University, School of Theology, 1970), p. 139. 
that create a special situation in which the rural-urban migrant feels more free to make changes and to accept new religious views. If the above concept concerning Sao Paulo's population is true, it should be applicable not only to Pentecostal Churches but also to the Adventist Church. Thus the favorable attitude of the population created by urbanization demands that the Church should reevaluate its strategies. Writing to Adventist ministers, Oosterwal points out that the Adventist mission today is not only a mission to the millions; it is a mission in and for the cities. ${ }^{1}$ If the Church fails to communicate the gospel to the cities, it fails in its whole mandate, for the world the Church must evangelize today is an increasingly urban world. Therefore, with courage, creativity, and the right action, the SDA Church must prepare itself to face the challenge of Urban Mission.

\section{Motivation for Church Mission}

Truman B. Douglas suggests in The Job Shirk that there are great areas of the world where Christian churches have not really penetrated. These are in the strongholds of Hinduism, Islam, and the culture of modern cities. ${ }^{2}$ In spite of the importance of the first two categories, this research is concerned with the last. More specifically, it is concerned with the problems which the Adventist Church faces in Sao Paulo. It is an appeal that out of "the constraining love of Christ" the Adventist organization should develop a deep awareness of the needs of the urban people and adequate strategies and motivation for

'Oosterwal, pp. 19, 20.

${ }^{2}$ Truman B. Douglas, quoted by Henry $\mathrm{J}$. Schmidt, in "The Urban Ethos," Mission Focus (September 1980), pp. 19, 20. 
meeting them. If the Church believes it is the earthly representative of God's love for lost men, then it must recognize that the evangelization of the cities is its most serious challenge.

God is always looking for men who cannot exist without Him. Heppenstall says that man must never be thought as separate from God.' Man has not given qualities by which he can function independently of God. The moment man thinks he is independent of God, he destroys his identity. No longer can he see himself or understand himself as man. On the other hand, because God is love, love requires fullness of expression. God as love cannot live by Himself in an empty universe. Love requires a beloved. God expressed himself in creatures akin to Himself by holding communion with them. ${ }^{2}$

This, then, is precisely the mission of the Church--to provide room for relationship between God and man. ${ }^{3}$ The Church is the instrument of faith in the city. Faith, understood in its real meaning is always man's reaction to God's primary action, ${ }^{4}$ and the Church exists in urban areas to stimulate the reaction of man in face of the divine action of God in the person of Jesus Christ. Thus one can say that the motivation of the SDA Church is love--the love of God for man and the love of God in the heart of the Church members that leads them to look for those who are lost in the sinful situation of the cities.

'Edward Heppenstall, Salvation Unlimited (Washington, D.C.: Review and Herald, 1974), p. 8.

2lbid., p. 8.

${ }^{3}$ Rudolf Bultmann, "Pisteuō. . .," Theological Dictionary of the New Testament, vol. 6 (Grand Rapids: Eerdmans, 1964-1976), p. 182 .

4 Ibid. 
In reality it is on the basis of the example of Christ and the apostles that the SDA Church must establish its mission strategy today. A glimpse at the New Testament Church shows that the apostles were concerned about the cities of their time. Certainly they learned that concern from Jesus himself, for the Bible tells that "Jesus went about all the cities and the villages, teaching . . . and preaching . . . and healing."1

The commitment of the Church should follow Paul's pattern as outlined in Apostles to the Cities by Roger Greenway: the conversion of sinners, the establishment of churches, and the witnessing of Christ's Lordship in society and in the world. ${ }^{2}$

In 1910 Ellen G. White ${ }^{5}$ wrote, "The work in the cities is the essential work for this time. When the cities are worked as God would have them, the result will be the setting in operation of a mighty movement such as we have not yet witnessed." ${ }^{3}$ God is seeking to help the people in the cities. He needs the helping hands of His Church in these huge urban centers. That he is a seeking, reconciling God is revealed in the act that immediately followed the rebellion of Adam and Eve. He sought them out, saying: "Where are you?" 4 God's great heart of love immediately responded to man's predicament and reached out for him. On the grounds of nakedness rather than disobedience Adam begged the

${ }^{1}$ Matt $9: 35$ (RSV).

${ }^{2}$ Roger Greenway, Apostles to the Cities (Grand Rapids, Baker Book House, 1978), pp. 79-96.

${ }^{3}$ E. G. White, Medical Ministry (Mountain View, Calif.: Pacific Press Publishing Association, 1910), p. 304.

${ }^{4}$ Gen 3:9 (RSV).

${ }^{5} E$. G. White (1827-1915) is a co-founder of the Seventh-day Adventist Church, a prolific writer, and accepted by Adventists as endowed with the prophetic gift described in the Bible. 
question and excused himself for hiding. All live in the dark shadow of Adam's sin. So all live in the shadow of the cross which reveals just how God's love led Him to redeem mankind. It is the merging of these two shadows that provides the Church with its mission in the cities of the world.

In very vivid words $E$. C. White spoke of the problem of the cities and called the attention of the Church to the challenge presented by them.

In the cities there are multitudes living in poverty and wretchedness, well-nigh destitude of food, shelter, and clothing; while in the same cities are those who have more than heart could wish, who live luxuriously, spending their money on richly furnished houses, on personal adornment, or worse still, upon the gratification of sensual appetites, upon liquor, tobacco and other things that destroy the power of the brain, unbalance the mind, and debase the soul. 1

And she further adds: "Much of the money that they thus invested had been obtained through exaction, through grinding down the poor." 2

The Church cannot endorse the notion that the city's progress has a price which must be paid by its inhabitants. Such a notion has been repeated in connection with even the most varied problems: from pollution of the environment to inadequate urban facilities, from insufficient transportation and bad housing to the rising crime rate and $\sin$.

Speaking on this subject, E. G. White has this comment:

${ }^{1}$ Ellen G. White, Testimonies for the Church, vol. 9 (Mountain View, Calif.: Pacific Press Publishing Association, 1938), p. 12.

2lbid., pp. 12-13. 
In the great cities are multitudes who receive less care and consideration than are given to dumb animals. Think of the families herded together in miserable tenements, many of them dark basements, reeking with dampness and filth. In these wretched places children are born and grow up and die....

Ragged and half-starved, they live amid vice and depravity, molded in character by the wretchedness and sin that surround them. Thus multitudes are trained to become criminals, foes to society that has abandoned them to misery and degradation. 1

After presenting the great problems of the cities she establishes the basis for the action of the Church. "In ministering to the poor there is a wide field of service for women as well as for men. ${ }^{2}$ She speaks of missionary families, of schools, of welfare activities. Thus there is a ministry that should be developed by the Church for those living in the urban area of Sao Paulo. The love of God gives no other way to face this reality.

\section{The Peculiar Mission of the SDA Church}

It is necessary now to consider the question, Why should the SDA Church try to proclaim its message in such a place as Sao Paulo? It is easy to observe that most of the Evangelical denominations in the area are growing rapidly. The SDA Church is not among those with the most rapid growth rate. Is there some special reason or plan in God's strategy for saving souls that makes it necessary for Adventists to propagate their faith in Sao Paulo?

At the outset there are three things of which the SDA Church needs to be reminded concerning its existence and task. It must see itself, as $L$. E. Froom points out, as a part of the Christian Church which

${ }^{1}$ E. G. White, The Ministry of Healing (Mountain View, Calif.: Pacific Press Publishing Association, 1943), pp. 183-208.

2lbid., p. 194. 
has spanned the whole of history. It needs to sense clearly that it is not simply another denomination, arising belatedly in the nineteenth century--too late to come under the category of the Reformation churches. Neither is it a cult holding certain strange, heretical positions. It is emphatically not a people apart, isolated and unrelated to God's true Church of the past. Instead, it is tied inseparably to the noble line of His designated people stretching across the centuries. ${ }^{1}$

Froom further asserts that every great truth believed and preached by the SDA Church was held in embryo by the Early Church prior to its departure from the apostolic faith. Thus there is continuity in both history and doctrine with the Church of the apostles.

This Adventist commission is a double-edged sword. The Word of God is to be preached to the unbelieving world so that people everywhere might be converted to Jesus Christ as their Saviour and follow Him as their Lord. In addition, the Church has the special commission to preach the Word of God in all of its revealed fulness so that God's people throughout the world might surrender themselves to its truth in preparation for the Lord's return. This humbling responsibility should serve to offset all sense of spiritual superiority.

This is its invulnerable position, a position of strength. It gives both depth and perspective to its commission and message. It provides greater power and appeal to its mission and witness to all men. ${ }^{2}$

Articulating this special aspect of the Adventist calling, Froom

${ }^{1}$ L. E. Froom, Movement of Destiny (Washington, D.C.: Review and Herald Publishing Association, 1971), p. 27.

Ilbid., p. 29. 
presses the point that God has His children--"My people"--scattered through various churches of Christendom today. In fact, the majority of God's true children are declared still to be therein. ${ }^{1}$ That is one of the basic reasons why Adventists have been called into being--to seek out, win, and bring them into God's final, visible Church so that at last there will be one fold and one shepherd ${ }^{2}$ before the return of the Lord consummates the ages.

The SDA Church mission in Sao Paulo is a mission which requires a visible, vocal witness. It is a mission abounding in imperatives. It is a mission Adventists dare not shirk. God will have it accomplished.

${ }^{1}$ E. G. White, The Great Controversy (Mountain View, Calif.: Pacific Press Publishing Association, 1950), pp. 383-90.

${ }^{2}$ E. G. White, Acts of the Apostles (Mountain View, Calif.: Pacific Press Publishing Association, 1911), pp. 583, 586. 
CHAPTER III

\section{SAO PAULO, ITS HISTORY AND PEOPLE}

\section{Historical Background}

One cannot develop a proper church-growth study in a particular geographical area without some understanding of its people and how they are related to the past. The history of a certain city helps one to understand the current trends of the population. For this reason it is necessary at the outset of this chapter to give a short historical background of Sao Paulo city.

The city of Sao Paulo was founded by Roman Catholic priests. As soon as the area where Sao Paulo now is located was discovered, the priests realized that it would be an ideal place to locate a center for the propagation of their religion in the southern part of the new country. With the help of some Indians, they built a large house that became a school which was inaugurated on January 25,1554 , the day celebrating the conversion of Saint Paul. For that reason the city was named Sao Paulo.

Through many years of the development of the city, the Catholic Church kept the population under its powerful influence. Churches were planted in every square and main street, and schools were built to give religious instruction to the new generations. The city grew old 
under the religious leadership of the Catholic priests. ${ }^{1}$

When slavery was abolished in 1888 in Brazil, European immigration began to flood Sao Paulo. The majority of the immigrants were Italians with a heavy Catholic background, and the Catholic Church again received the total support of that part of the population. As a result of this historical background and the activities of the Catholic Church, Sao Paulo became a Catholic city. Today the Catholic Church still has a very important influence on the population as a whole (see table 4).

TABLE 4

CATHOLICS IN GREATER SAO PAULO TODAY

\begin{tabular}{lccc} 
Discrimination & Year & $\circ$ & Number \\
\hline $\begin{array}{l}\text { Roman Catholics in } \\
\text { total population }\end{array}$ & 1979 & 87.62 & $11,310,000$
\end{tabular}

Source: IBGE : Demography and Religion.

The Immigrants and the New Era

The immigration process went on but not only foreign immigrants came to Sao Paulo. There were many people who brought their savings to invest in industry and commerce and this explains the growth of population by the end of the nineteenth century. The foreign population grew from 8 percent to 25 percent of the total population in the last decade of the nineteenth century. The number of Italians in the

\footnotetext{
${ }^{1}$ Rocha Pombo, Historia de Sao Paulo (Sao Paulo: Cia Melhoramentos, 1918), p. 48.
} 
city was enormous, outnumbering the Brazilians two to one. This caused Moreira Pinto, the Brazilian historian, to consider Sao Paulo an Italian city.

In the time between 1882 and $1891,263,196$ immigrants came through the port of Santos, of those 202, 503 were Italians, 25, 925 Portuguese, and 14,954 Spanish. During the same period Germans, Russians, Frenchmen, Danes, Belgians, Englishmen, Swedes, Irishmen, and others totalled 19,814 immigrants.

From the ethnic point of view, Sao Paulo became a world city, for it was a micro-cosmos, a new Babel. In 1955, there were representatives of eighty-three nationalities within the municipality. Today the number is even larger.

While these migration processes were taking place, Sao Paulo underwent a marked change in urban and population aspects. Geographically, the city is divided into three definite areas: (1) the central nucleus between the Tiete and Pinheiros Rivers, and divided by the ridge of the Paulista Avenue; (2) the $A B C D$ industrial area; and (3) the area of Pinheiros from Butanta to Santo Amaro. These areas make up Greater Sao Paulo, which in the 1970s grew 68 percent, reaching a population of thirteen million.

Due to its rhythm of growth and development, Sao Paulo is a city reborn every day, where the word old has no significance. There are few remains of the past. The observations of Brazilian urbanists is that Sao Paulo is a city where more people move in the streets than in any city in the world. 1

\footnotetext{
${ }^{1}$ Arroyo, Sao Paulo, pp. 3-4.
} 
It seems that the growth of any Evangelical church in Sao Paulo today is related to the way it develops a proper outreach strategy that fits the Catholic mind of the community and the environment created through the years. The society of Sao Paulo reflects the lifestyle established by the Catholic priests. They played a decisive role in the formation of the Paulistan society. This is the subject of the next section of this chapter.

\section{The Challenge of Social Structure}

There are many different aspects to deal with in big cities like Sao Paulo. The Church must be aware of the social structure of the Paulista population in order to develop adequate strategies for working to supply the needs of the people. It is important to study these social realities of Sao Paulo.

There are three distinct social groups in Sao Paulo that deserve special attention--the poor, the middle class, and the upper class. It is suggested that because each of these groups has very specific characteristics, the SDA Church should develop an adequate method of action appropriate to each group.

The first social group is the one usually not mentioned by tourism bulletins or historians in general. It is in this group that the SDA Church has most of its members and from which a significant number of the recent conversions are coming.

In the region of Greater Sao Paulo, about 12.5 percent of the labor force are self-employed, while 1.6 percent are family members earning no income (they generally work for the head of the family). It is reasonable to estimate that 10 percent of the labor force in Greater 
Sao Paulo is employed in the public sector. Thus one concludes that 76 percent of the total labor force works in privately owned companies, 72 percent as employees ${ }^{1}$ (see table 5).

\section{TABLE 5}

THE WORK FORCE, UNEMPLOYMENT AND

INACTIVITY BY SEX AND AGE IN GREATER SAO PAULO IN 1972

\begin{tabular}{|c|c|c|c|c|c|c|}
\hline \multirow[b]{2}{*}{ Age Groups } & \multicolumn{2}{|c|}{$\begin{array}{l}\text { \% of Total } \\
\text { Population in } \\
\text { Work Force }\end{array}$} & \multicolumn{2}{|c|}{$\begin{array}{l}\text { Unemployed as } \\
\text { \% of Work Force }\end{array}$} & \multicolumn{2}{|c|}{$\begin{array}{l}\text { \% of 'Others' in } \\
\text { Total Population }\end{array}$} \\
\hline & Men & Women & Men & Women & Men & Women \\
\hline $10-14$ & 9.4 & 7.7 & 12.0 & 6.6 & 10.8 & 7.7 \\
\hline $15-19$ & 70.0 & 49.5 & 8.6 & 7.2 & 6.5 & 2.9 \\
\hline $20-24$ & 91.0 & 51.0 & 4.7 & 4.6 & 2.3 & 1.0 \\
\hline $25-29$ & 96.8 & 38.7 & 2.5 & 1.4 & 1.4 & 1.1 \\
\hline $30-39$ & 94.8 & 34.2 & 1.3 & 2.4 & 1.6 & 0.6 \\
\hline $40-49$ & 92.6 & 30.6 & 0.7 & 0.5 & 3.9 & 0.4 \\
\hline $50-59$ & 74.9 & 20.2 & 0.6 & 0.3 & 23.3 & 2.9 \\
\hline $60-69$ & 46.0 & 10.3 & 0.4 & - & 43.0 & 4.4 \\
\hline 70 plus & 16.1 & 1.5 & -- & -- & 64.1 & 18.3 \\
\hline Total & 73.6 & 31.6 & 3.0 & 4.0 & 8.4 & 2.9 \\
\hline or more & 84.4 & 35.3 & & & & \\
\hline
\end{tabular}

Source: PNAD, Regiōes Metropolitanas. $4^{\circ}$ trimestre, 1971-1972, Rio de Janeiro, IBGE, n.d.

In some way or other, church members in this situation manage to give stability to church income. In spite of the low per capita income, the fidelity of the church members results in a constant monthly income for the church treasury. The situation in rural churches where the income depends on the crops is completely different, but achieving higher church

\section{${ }^{1} \mathrm{P}$. Singer, A Economia Politica da Urbanizacao (Sao Paulo,} Editora Brasiliense, 1973), p. 55.

${ }^{2}$ Persons who are neither occupied in domestic tasks, nor go to school, or are incapable of working. 
income or maintaining a more steady income is not the reason why the Church must give special attention to the people living in such areas.

The process of growth in which capital expands by assimilating its own product-profit is what is called capital accumulation. As early as 1948, Sao Paulo already held a dominant position in the process of capital accumulation and was responsible for no less than 45 percent of all capital issues in Brazil. ${ }^{1}$

After a temporary fall during the first half of the 1960 s, Sao Paulo's share again climbed to over 40 percent, and in 1972 reached the figure of 44 percent. This means that capital in Brazil is highly concentrated in Sao Paulo, which receives resources for accumulation both from the rest of the country and from abroad.

The book Sao Paulo--Growth and Poverty, a report from the Sao Paulo Justice and Peace Commission, examines the other side of this economic miracle. Through an analysis of the working and living conditions of the majority of its people it exposes the misery and poverty of Sao Paulo. The book says that Sao Paulo has two images superimposed: on the one hand the growing accumulation of wealth and on the other increasing misery and poverty. Official ideology and propaganda glorify the prosperity and turn a blind eye to the heavy human costs of this pseudo-progress. There is something hidden in the city: something about which the ruling classes pretend ignorance, something that tourists never see, but something that the Church should know and be concerned with.

${ }^{1}$ Cândido Procópio Ferreira de Camargo, Sao Paulo--Crowth and Poverty (London: The Bower Dean Press, 1978), pp. 19, 20. 
Table 6 shows how the family income affects the nutrition of the population.

TABLE 6

MUNICIPALITY OF SAO PAULO: NUTRITION

LEVELS FOR WORKING POPULATION BY

FAMILY INCOME (1969-70)

\begin{tabular}{|c|c|c|c|c|}
\hline \multirow[b]{2}{*}{ Nutrient } & \multirow[b]{2}{*}{ Average } & \multicolumn{3}{|c|}{ Level of Family Income } \\
\hline & & $\begin{array}{l}\text { Up to } 3.0 \\
\text { Minimum } \\
\text { Wages }\end{array}$ & $\begin{array}{l}\text { From } 3.1 \text { to } \\
6.2 \text { Minimum } \\
\text { Wages }\end{array}$ & $\begin{array}{l}6.2 \text { Minimum } \\
\text { Wages and } \\
\text { Above }\end{array}$ \\
\hline $\begin{array}{l}\text { Calories } \\
\text { Proteins } \\
\text { Calcium } \\
\text { Iron } \\
\text { Vitamin A } \\
\text { Thiamin } \\
\text { Riboflavin } \\
\text { Niacin } \\
\text { Ascorbic Acid }\end{array}$ & $\begin{array}{r}99.8 \\
95.5 \\
50.8 \\
107.1 \\
36.0 \\
74.3 \\
63.0 \\
110.2 \\
77.8\end{array}$ & $\begin{array}{r}91.1 \\
86.2 \\
41.9 \\
101.1 \\
26.2 \\
72.0 \\
53.9 \\
95.7 \\
56.3\end{array}$ & $\begin{array}{r}100.6 \\
95.4 \\
50.0 \\
107.6 \\
35.6 \\
74.3 \\
62.0 \\
110.2 \\
79.1\end{array}$ & $\begin{array}{r}109.6 \\
108.1 \\
65.4 \\
114.3 \\
49.8 \\
77.4 \\
77.6 \\
128.6 \\
104.0\end{array}$ \\
\hline $\begin{array}{l}\text { Overall nutrien } \\
\text { profile* }\end{array}$ & $\begin{array}{l}\text { Good } \\
\text { Bad } \\
\text { Very bad }\end{array}$ & $\begin{array}{l}2 \\
2 \\
5\end{array}$ & $\begin{array}{l}4 \\
1 \\
4\end{array}$ & $\begin{array}{l}5 \\
2 \\
2\end{array}$ \\
\hline
\end{tabular}

Source: DIEESE, 'Família assalariada: padrāo e custo de vida', Estudos Sócio-Econômicos (2), January 1974.

* Levels: Good--over 95.0

Bad--from 75.0 to 94.9

Very bad--below 75.0

It is evident that future generations will reflect the present economic level of most of the people living in Sao Paulo presently.

Paulo Evaristo Arns, archbishop of Sao Paulo, states:

In these times, however, it is not good enough merely to sympathize with the problem or to be moved by the misery and wretchedness, nor even to search for a palliative to offer those who work at our door. It is not even enough that there are organizations dedicated to ameliorating the sufferings of the sick, the old and 
the abandoned. We must actively seek the causes of these evils and organize ourselves to combat them with courage, patience and determination. 1

Arns sees the solution in the formula presented by the Liberation Theology that intends to overthrow the present political status quo and establish a new philosophy of government.

The conditions in which most of the Paulistanos live depend on a series of factors which are linked directly or indirectly to the system of production and distribution of wealth. For the population of Sao Paulo the majority of which are wage-earners it is the organization of work which is decisive. This is true in terms of the conditions in which the work is done and the wages which are paid, which in turn determine the people's access to available goods and services. Plots of land and houses cost more in areas with better amenities, and property prices serve as a mechanism for reserving both properties and municipal services for those who can pay more. The geographical distribution of the population in the city is thus determined by the social position of the inhabitants and this in turn reinforces existing inequalities (see table 7).

Many years ago a shanty-town dweller wrote that the "shantytown is the city's rubbish heap." 2 Nowadays, the term periphery, which is used to designate districts far removed from the center, has in certain circles become synonymous with the idea of marginality and social rejection. In this area are located about 60 percent of the SDA

${ }^{1}$ Camargo, p. 15.

${ }^{2} \mathrm{M}$. C. de Jesus, Quarto de Despejo: Diario de Uma Favelada (Sao Paulo: Livraria Francisco Alves, 1960), p. 50. 
TABLE 7

GREATER SAO PAULO AVERAGE NUMBER OF RESIDENTS PER . BEDROOM (1970)

\begin{tabular}{|c|c|c|c|}
\hline Municipality & $\begin{array}{l}\text { No. of } \\
\text { Residents }\end{array}$ & $\begin{array}{c}\text { No. of } \\
\text { Bedrooms* }\end{array}$ & Residents \\
\hline $\begin{array}{l}\text { Aruja } \\
\text { Barueri } \\
\text { Biritiba-Mirim } \\
\text { Caieiras } \\
\text { Cajamar } \\
\text { Carapicuiba } \\
\text { Cotia } \\
\text { Diadema } \\
\text { Embu } \\
\text { Embu-Guacu } \\
\text { Ferraz de Vasconcelos } \\
\text { Francisco Morato } \\
\text { Franco da Rocha } \\
\text { Guararema } \\
\text { Guarulhos } \\
\text { ltapecerica da Serra } \\
\text { Itapevi } \\
\text { Itaquaquecetuba } \\
\text { Jandira } \\
\text { Juquitiba } \\
\text { Mairipora } \\
\text { Maua } \\
\text { Mogi das Cruzes } \\
\text { Osasco } \\
\text { Pirapora do Bom Jesus } \\
\text { Poa } \\
\text { Ribeirao Pires } \\
\text { Rio Grande da Serra } \\
\text { Salesopolis } \\
\text { Santa Isabel } \\
\text { Santana do Parnaiba } \\
\text { Santo Andre } \\
\text { Sao Bernardo do Campo } \\
\text { Sao Caetano do Sul } \\
\text { Sao Paulo } \\
\text { Suzano } \\
\text { Taboao da Serra } \\
\text { Sa }\end{array}$ & $\begin{array}{r}8,972 \\
36,889 \\
8,853 \\
14,089 \\
10,215 \\
51,900 \\
28,244 \\
75,544 \\
17,457 \\
9,120 \\
23,645 \\
11,091 \\
21,310 \\
12,085 \\
225,377 \\
23,471 \\
26,686 \\
27,336 \\
11,770 \\
6,427 \\
18,829 \\
98,228 \\
135,798 \\
274,235 \\
3,504 \\
31,054 \\
28,215 \\
7,564 \\
9,032 \\
16,577 \\
5,125 \\
404,140 \\
191,864 \\
145,366 \\
641,330 \\
53,013 \\
39,156\end{array}$ & $\begin{array}{r}3,174 \\
11,293 \\
3,204 \\
5,058 \\
3,678 \\
16,558 \\
10,383 \\
22,028 \\
5,355 \\
3,285 \\
7,319 \\
3,327 \\
7,644 \\
4,482 \\
73,630 \\
8,115 \\
8,200 \\
8,417 \\
3,435 \\
2,322 \\
6,792 \\
29,739 \\
48,629 \\
91,138 \\
1,458 \\
10,072 \\
9,941 \\
2,444 \\
3,238 \\
6,044 \\
2,144 \\
148,038 \\
68,847 \\
55,963 \\
239,201 \\
18,118 \\
11,590\end{array}$ & $\begin{array}{l}2.8 \\
3.2 \\
2.7 \\
2.7 \\
2.7 \\
3.1 \\
2.7 \\
3.4 \\
3.2 \\
2.7 \\
3.2 \\
3.3 \\
2.7 \\
2.6 \\
3.0 \\
2.8 \\
3.2 \\
3.2 \\
3.4 \\
2.7 \\
2.7 \\
3.3 \\
2.7 \\
3.0 \\
2.4 \\
3.0 \\
2.8 \\
3.0 \\
2.7 \\
2.7 \\
2.3 \\
2.7 \\
2.7 \\
2.5 \\
2.5 \\
2.9 \\
3.3\end{array}$ \\
\hline Greater Sao Paulo & $7,753,509$ & $2,964,301$ & 2.6 \\
\hline
\end{tabular}

Source: VIII Recenseamento Geral--1970. Censo Demografico--Sao Paulo, IBGE, Rio de Janeiro, 1973.

*Including other rooms used as bedrooms. 
Church members and about 70 percent of the total population. This is the place where the gospel must be presented in connection with the welfare program of the Church. This is the place where the love of Jesus must be represented by action and not theory.

Another very meaningful challenge faced by the Church in its mission in Sao Paulo is its relationship to the growing middle-class population. Due to housing shortages and inflation, the number of apartment dwellers is increasing in areas close to the basic center of the city.

David Rich has characterized apartment dwellers as anonymity and privacy seekers, extremely mobile, suspicious of institutions-the church included--and rootless. ${ }^{1}$ With inflation and rising housing costs many younger families and older persons have become apartment dwellers for economic rather than escape reasons. While Rich's classification may seem stereotyped there is evidence apartment dwellers have fewer roots and relationships in their immediate environment than do those who dwell in single-family housing. The apartments are organized as condominiums and have a tendency to exclude all outsiders. The population of the apartments is growing each year with the increase of the number of apartment buildings. Most of the middleclass families are related to this new urban situation today.

The third but not least important project for the SDA Church to develop a mission ministry is the area where the rich people of Sao Paulo live. The Adventists understand that God today, as in the past, is seeking for souls among all classes of the society. It seems

\footnotetext{
${ }^{1}$ Schmidt, "The Urban Ethos," p. 25.
} 
that the Church is biased against the wealthy in Sao Paulo. Many have used the words of Jesus, "a rich man shall hardly enter into the kingdom of heaven" (Matt 19:29), to justify the lack of a plan to reach the rich area of Sao Paulo with the gospel of Jesus Christ.

For years the Church has looked upon the wealthy as hopeless, and has done little to open the eyes of those who, blinded and dazed by the glitter of earthly glory, have excluded eternity from their reckoning. Thousands of wealthy men have gone to their graves unwarned. But indifferent as they may appear, many among the rich are soul-burdened.' Riches and worldly honor cannot satisfy their souls. They are longing for some divine assurance, some spiritual hope. 2

High society in Sao Paulo is characterized by three primary factors that shape the modern consciousness: (1) secularization, (2) pluralization, and (3) privatization. ${ }^{3}$

Secularization is the process by which religious ideas and institutions lose their significance and influence in modern society. It is felt that in the high level of Paulista society people worship the present, and Christian ideals have become less meaningful because the secularist trend is removing the supernatural from life in general and from Christianity in particular.

Pluralization is the process in modern society by which the number of choices and options is greatly accelerated. This is

\footnotetext{
${ }^{1}$ White, Ministry of Healing, p. 210.

2 Ibid.

${ }^{3}$ Schmidt, "The Urban Ethos," p. 27.
} 
illustrated by the diversity of lifestyles, hobbies, fashions, subcultures, restaurants, etc., found in the central part of Sao Paulo. Pluralization has a deep impact on religion. In fact, it reduces Adventism to one of the options in the marketplace of religions. If secularism makes religion less real in terms of the supernatural, pluralization makes Adventism just one of the many religious options.

Privatization is a technical sociological term used to describe the separation of the public and the private spheres in an expanding, industrialized, urbanized culture like the one found in Sao Paulo city.

An understanding of the implications of secularization, pluralization and privatization is extremely important for the SDA Church to develop a proper outreach strategy for the society of Sao Paulo.

The rate of growth is often closely dependent upon the structure of the society in question. If, for example, a church is witnessing to a face-to-face society (one in which most of the people of a city know one another), it usually either reaches the entire group or splits the society along class or family lines. ${ }^{1}$ In an urban society like Sao Paulo's church growth is more likely to follow geographical, occupational, and friendship lines than family ones. It is understood that the knowledge of the social structure of the Sao Paulo metropolitan area is helpful in the development of a strategy for church growth in such an area.

${ }^{1}$ Eugene A. Nida, "Culture and Church Growth," Church Growth and Christian Mission, Donald McGavran, ed. (New York: Harper and Row, Publishers, 1965), pp. 94-95. 


\section{BRAZIL}

\section{Population--Demographic Density in the States--1979}

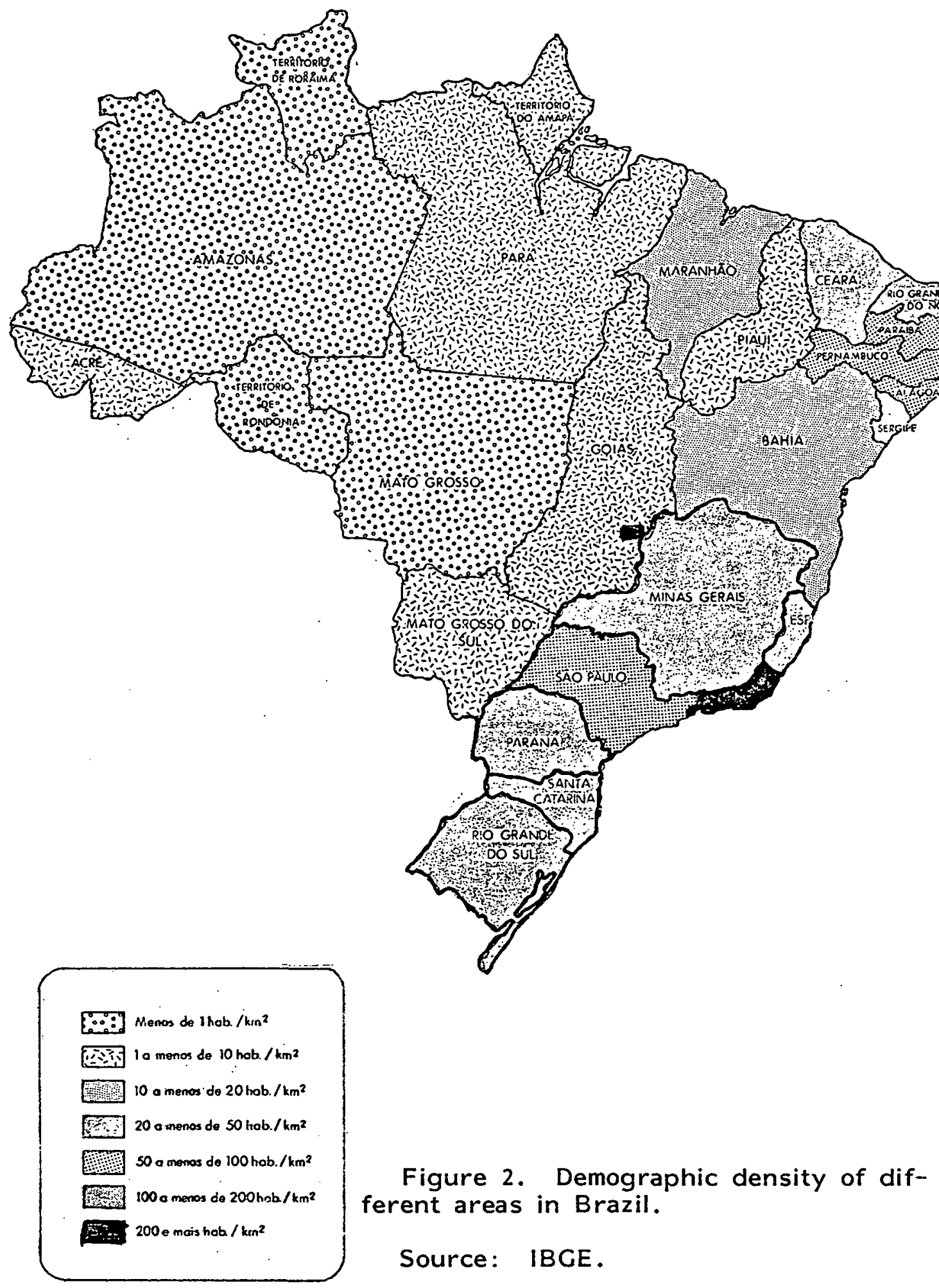




\section{CHAPTER IV}

\section{THE RELIGIOUS PANORAMA OF SAO PAULO TODAY}

Each city has its own peculiar religious "personality" that reflects the total spectrum of the several religious groups that operate among its inhabitants. Robert N. Bellah states that religion is a set of symbolic forms which relate man to the ultimate conditions of his existence. ${ }^{1}$ It seems that this is true in the city of Sao Paulo where religious groups are growing in proportion with their response to the reality of the existence of the people.

Since a knowledge of the religious structure of Sao Paulo is important for the purpose of this study which is intended as a tool to help the SDA Church to develop an adequate outreach strategy, attention is now turned to those religious groups which have a significant number of communicants.

\section{Roman Catholicism}

The city of Sao Paulo wasborn of a religious-political act. The Roman Catholic Church and the Portuguese government worked together in the establishment of the new school that became the embryo of the great metropolis of today.

${ }^{1}$ Robert N. Bellah, "Religious Evaluation," American Sociological Review 30 (June, 1964):358-74. 
Since then Catholicism almost totally dominated the population until 1860 when Protestantism was introduced with the establishment of the Presbyterian Church. Through those early years, Sao Paulo was the base for the expansion of Catholicism in Brazil, but by the turn of the century, with the coming of industrialism, the population was opened to the vast influence of other religions.

However, in spite of that, the Catholic Church still holds the greatest influence in the religious life of the population.

In July of 1980, at the time Pope John Paul II visited Sao Paulo, a statistical report noted that 87.56 percent of the population were Roman Catholic communicants. ${ }^{1}$ This present research discovered that even today most of the new SDA converts come from the traditional Catholic people of Sao Paulo. It is important to note that there are two "Catholicisms" in Sao Paulo: one is the traditional or "folk" Catholicism; the other is Roman-oriented Catholicism. Traditional Catholicism developed in times past in rural areas. The vast diocesan territories, the lack of priests, familial religion, and an over-accommodation to local cultures helped to produce the folk Catholicism. ${ }^{2}$

This type of Catholicism brought from the country by ruralurban migrants exists in Sao Paulo's suburban areas.

The second Catholicism is that oriented toward Rome. In general it is more closely related to a higher level of society and the

1 SEAD, 1980.

${ }^{2}$ Alfonso Gregory, A Igreja no Brasil (Rio de Janeiro: Federaçăo Internacional dos Institutos Católicos de Investigaçōes Sociais e Socio-religiosas, 1965), p. 82. 
priests are more intellectually trained. It is a Catholicism of the religious orders that try to counteract the secularism which especially affects the men by dealing with the women and children. Roman Catholicism oriented toward Rome reaches the women through the confessional and the children through their dayschool. 1

The folk Catholics are easily reached by Adventist public meetings held in the suburbs of Sao Paulo. One cannot say the same in relation to the Rome-oriented Catholics. They are better educated and they belong to the upper class of society, and to make decisions toward a new faith means a complete re-orientation of their life-style.

\section{The Evangelical Churches}

Although Sao Paulo is nominally a Catholic city, Protestantism has grown very rapidly in recent decades. The rapidly growing Evangelical movement now has about one million communicants. But to give a true picture of the Evangelicals in Sao Paulo it is necessary to separate them into two groups--the traditional Evangelical churches and the Pentecostals. The traditional Evangelicals are mainly represented by the Baptist, Presbyterian, and Methodist churches. The other Evangelical churches are insignificant for the purpose of this study. The three basic components of Sao Paulo Pentecostalism are Christian Congregation of Brazil, the Assembly of God, and the Brazil-for-Christ churches. Other smaller elements are: the Crusades

${ }^{1}$ Cândido Procópio Camargo, "Essai de Typologie du Catholicisme Bresilien," Social Compass, 1967, 399-422. Camargo distinguishes correctly between traditional Catholicism found in rural and urban areas, and "internalized" Catholicism, or Cathol icism emphasizing the socialization of individuals to a conscious style of life characterized by individual rational choices. 
of the New Life, the Church of Renovation, the Bible Revival, the International Church of the Four Square Gospel, and other even more independent groups. ${ }^{1}$ Emile $G$. Leonard points out that the Pentecostals are classified as the illuministic group. ${ }^{2}$

The traditional Evangelical churches in the past thirty years increased from 15,000 to 55,000 members in Sao Paulo. In the same period, the Pentecostal churches, starting with less than 10,000, increased to more than 800,000 members. There has been a higher Evangelical growth rate in Sao Paulo than in other areas of Brazil, largely because of the Pentecostals. ${ }^{3}$ However, the main concern of the Pentecostals has been membership growth. Thus they ignore, to a great extent, the social services which have been so important to Spiritism and traditional Evangelical churches.

According to the Evangelical and Pentecostal Confederation of Sao Paulo, there are currently about one million evangelical communicants in Greater Sao Paulo. That means approximately 10 percent of the total population.

The growth of Evangelical denominations has not been viewed with sympathy by Roman Catholic leaders. Some fear a Catholic decline as the processes or urbanization and industrialization weaken

${ }^{1}$ For a description of the Pentecostal and traditional churches see Read, pp. 19-205.

${ }^{2}$ Many Roman Catholics include all Protestant groups which emphasize the importance of the Holy Spirit under the name of illuminism. Cf. Emile G. Leonard, L'illuminisme dans un Constitution Recent (Paris: Presse Universitaire, 1953), p. 45.

${ }^{3}$ Lynn T. Smith, Brazil: People and Institutions (Baton Rouge: Louisiana State University Press, 1963), p. 526. 
the traditional rural orientation of the Catholic faith. ${ }^{1}$ Others fear that the "sect-like" characteristics of many of the Evangelicals will be more appealing to people caught up in a rapidly changing society than would the Roman Catholic "church-like" characteristics. ${ }^{2}$ In spite of this, the Evangelical Confederation of Brazil has tried to develop a friendly dialogue between Roman Catholics and Evangelicals, encouraged by the Second Vatican and the World Council of Churches. The formation of the Pentecostal Confederation of Brazil and ecumenical efforts by members of the Brazil-for-Christ movement indicate a desire for greater cooperation among previously aloof Pentecostals. ${ }^{3}$ However, another aspect is making its impact on the spiritual welfare of Sao Paulo. To this attention is now turned.

\section{Non-Christian Religions}

It has been noted that the Catholics have a great influence on the Sao Paulo metropolitan population and that the Evangelicals are growing at a far more rapid rate than the general population. But the major "mass movement" in Sao Paulo now is composed of two nonChristian religions--Spiritualism and Umbanda.

${ }^{1}$ Francois Houtart, "Les Effects du Changement Social Sur la Religion Catholique en Amerique Latine," Archives de Sociologie des Religions 12 (Juillet-Decembre, 1961):63-74.

${ }^{2}$ Church-sect differentiation has been a major area of attention in sociology of religion, but a brief characterization can be found in Liston Pope, Millhands and Preachers: A Study of Gastonia (New Haven, Conn.: Yale University Press, 1965), pp. 122-24.

${ }^{3}$ Antonio de Campos Gonçalves, "Evangelism in Brazil Today," The International Review of Missions, 48 (1959):302-308. 
Spiritism

The basic source for Brazilian spiritualism is the Book of Spirits, written by the Frenchman known as Allan Kardec. Professional and upper class people are the most interested in the Spiritist type of preaching. 1 Those interested usually meet in private homes to have special sessions. The doctrines of current Kardecist Spiritist groups in Sao Paulo emphasize that each human being is a spirit trapped in a material body. This spirit is of an immaterial nature, but is covered by a "peri-spirit" which is semi-material. The perispirit gives the individual his personality which is the chief link between the spirit and the body. When the material body dies the spirit continues to live enclosed by the semi-material peri-spirit. Ordinarily nobody can see the spirit in its new condition, but on certain occasions it can become not only visible but tangible and audible as well.

Moral perfection is the goal of human life, and each spirit must pass through many incarnations to achieve it. Egoism, pride

${ }^{1}$ The majority of Spiritists do not accept the teaching of the Bible as a final authority. They deny the doctrine of the Trinity, overemphasizing the Holy Spirit. They deny the centrality of Christ by considering $\mathrm{Him}$ a superior spirit but not of the same essence as the Father. God has no qualities that human beings may recognize. In making man, God was an imperfect craftsman and there is, therefore, no need for a doctrine of original sin. The spirits incarnate themselves in matter. and in the process purify themselves. Sin is not a rebellion against God, but something built into creation. Sin is merely a limitation which will disappear. Redemption is a human effort, not a divine work. Spiritism teaches three basic doctrines which are unacceptable to Christianity: reincarnation, communication between the dead and the living, and a plurality of worlds, correlated to personal ethics. Allan Kardec, O Que é O Espiritismo? Introducăo Ao conhecimento do Mundo Invisivel pelas Manifestaçoes dos Espiritos (Sao Paulo: Empresa Editora "O Pensamento," 1967), pp. 17-25. 
and self-indulgence hinder an individual from reaching the goal, while love for neighbors advances him. All men eventually reach the goal of moral perfection, but some take less time than others because of their greater desire. Thus the good people met on this earth are the incarnations of "evolved spirits, ${ }^{1}$ and the bad people are poorly evolved spirits. Usually when a good man evokes the spirits at a seance, a good spirit will respond. The Kardecist mediums do not, as a rule, try to enter into contact with the spirit of a particular individual, such as the deceased member of a family.

While these are the basic beliefs of Spiritism, there is another reason for its strong presence in Sao Paulo. This is especially due to its social services to the poor and its cure of the sick. Measured by the proportion of social service institutions to members, Spiritism is Sao Paulo's most outgoing religion. ${ }^{2}$

Mediums under the guidance of "medically trained spirits" give therapeutic advice and medical prescriptions. This is very attractive to the people, and as an urban religion in Sao Paulo, Spiritism has given evidence of a capacity for very rapid growth. ${ }^{3}$

${ }^{1}$ Allan Kardec, O Que é O Espiritismo? trans. Julio Abreu Filho (Sao Paulo: Editora "O Pensamento" Limitada, 1956), p. 103.

${ }^{2}$ Although Spiritism has as members only 1.5 percent of the population, it maintains over 36 percent of the social service institutions. The Spiritist gives well over eight times more money to charity than does the Roman Catholic. Cf. McGregor, p. 218.

${ }^{3}$ Emilio Willems considers the growth of Spiritism together with Protestantism and Umbanda, "the largest religious mass movement in the history of Brazil, perhaps of Latin America." Willems, "Religious Mass Movements and Social Change in Brazil," p. 230. It is difficult to gain an accurate idea of Spiritist growth. Official figures show a growth from 488,017 members in 1953 and 680,511 in 1960. Anuário Estatístico do Brasil (Rio de Janeiro: Conselho Nacional de Estatística, 1960). This 
Umbanda

The Spiritism in the Brazilian urban situation blended together with folk Catholicism and African beliefs has resulted in a new religion regarded as typically Brazilian. Today it is considered by many scholars as the fastest-growing religious movement in Sao Paulo. The name of this new Spiritist group is Umbanda.

The essence of Umbanda is that deity incarnates itself in human instruments. The orixás (African gods) come down in the form of Brazilian caboclos (countrymen) and preto velho (old negro). Many of the important orixás have been given the names of Catholic saints. As long ago as 1942, Pierson listed the following identification in Bahia :

Ogún, the god of war, with Saint Anthony

Oxossi, the god of the hunt, with Saint George

Oxalá, the central orixá, with o Senhor do Bomfim (Jesus

Christ)

Omulu, the god of pestilence, with Saint Roque

Exu, the messenger of the gods, with Satan (this is not accepted by some cult leaders in Bahia)

Xangô, the god of lightning and thunder, with Saint Jerome lêmanjá, the female water deity, with Nossa Senhora da

Piedade (the Virgin Mary)

Beji, the two gods, with Cosme and Damian

cnits Spiritists who meet in homes and are not attached to a center as well as Spiritists who list themselves as Catholics for social reasons. 
Ifa, the god of divination, with the Santíssimo Sacramento (the Most Holy Sacrament). ${ }^{1}$

The syncretistic fusion between orixá and saint is aided by the fact that in both belief systems, the deity is both protector and a troubler of human beings. He is a source of assistance if the rituals are properly observed, but a source of misfortune if they are not.

In an atmosphere of drum beats and sacred songs, the gods are asked to incarnate themselves in their filhas (daughter). As each god descends, the recipient loses consciousness and takes on the characteristics of the possessing god. When she has fully entered the trance-like state, or disassociation from her rational consciousness, she retires to the peji (room) to put on the proper ritual clothing. Returning to the central room of the spectators and worshippers, the filhas, dressed as gods, make a triumphal entry. They are accompanied by ekedes, or assistants, whose function is to protect them from harming themselves while in a state of possession.

The filha as the incarnation of a god may give limpezas (ritual cleansing) and protection for the future, as well as consultas (advice) to those afflicted with a variety of human ills.

The Umbanda in reality is a very attractive religion for the lower class of people of Sao Paulo. It appeals to the eyes, to the ears, and to the feelings. There are colors, movements, and music, and the worshippers are part of an experience in which they receive promises and assurance for the future.

1D. T. Pierson, Negroes in Brazil : A Study of Race Contact at Bahia (Chicago: The University of Chicago Press, 1942), pp. 282-83. 
Jose' Comblin, a well-known Catholic theologian, points out that Umbanda is growing everyday. There are no official statistics, but he believes that in Sao Paulo there are at least 30,000 terreiros-buildings of worship--and about one million umbandistas--members of this non-Christian religion. ${ }^{1}$ (See figure 3 for a religious panorama of Sao Paulo today.)

\section{The SDA Church in Sao Paulo}

Early History: 1894-1908

The Adventists trace the beginning of their missionary work in Sao Paulo back to 1894 when Albert B. Stauffer, a colporteur, was sent from the United States to sell SDA publications. Stauffer worked first in Sao Paulo and then, successively, in Rio de Janeiro and the State of Rio Grande do Sul. ${ }^{2}$ There is no report about the results of Stauffer's work in Sao Paulo. Only the fact that he was the first worker in Sao Paulo remains.

Stauffer was followed by two other colporteurs, E. W. Snyder and C. A. Nowlen. It seems that while Stauffer worked in the State of Rio Grande do Sul, Snyder took over the work in Rio de Janeiro.

The early records of these pioneer SDA Church planters indicates that they used personal evangelism as their method and a private home as their evangelistic hall.

At a sailor's home in Rio de Janeiro, Snyder met Alberto

1 José Comblin, Os Sinais dos Tempos e a Evangelizaçăo (Recife: Duas Cidades, 1968), pp. 285-86.

${ }^{2}$ :Neufeld, p. 184. 

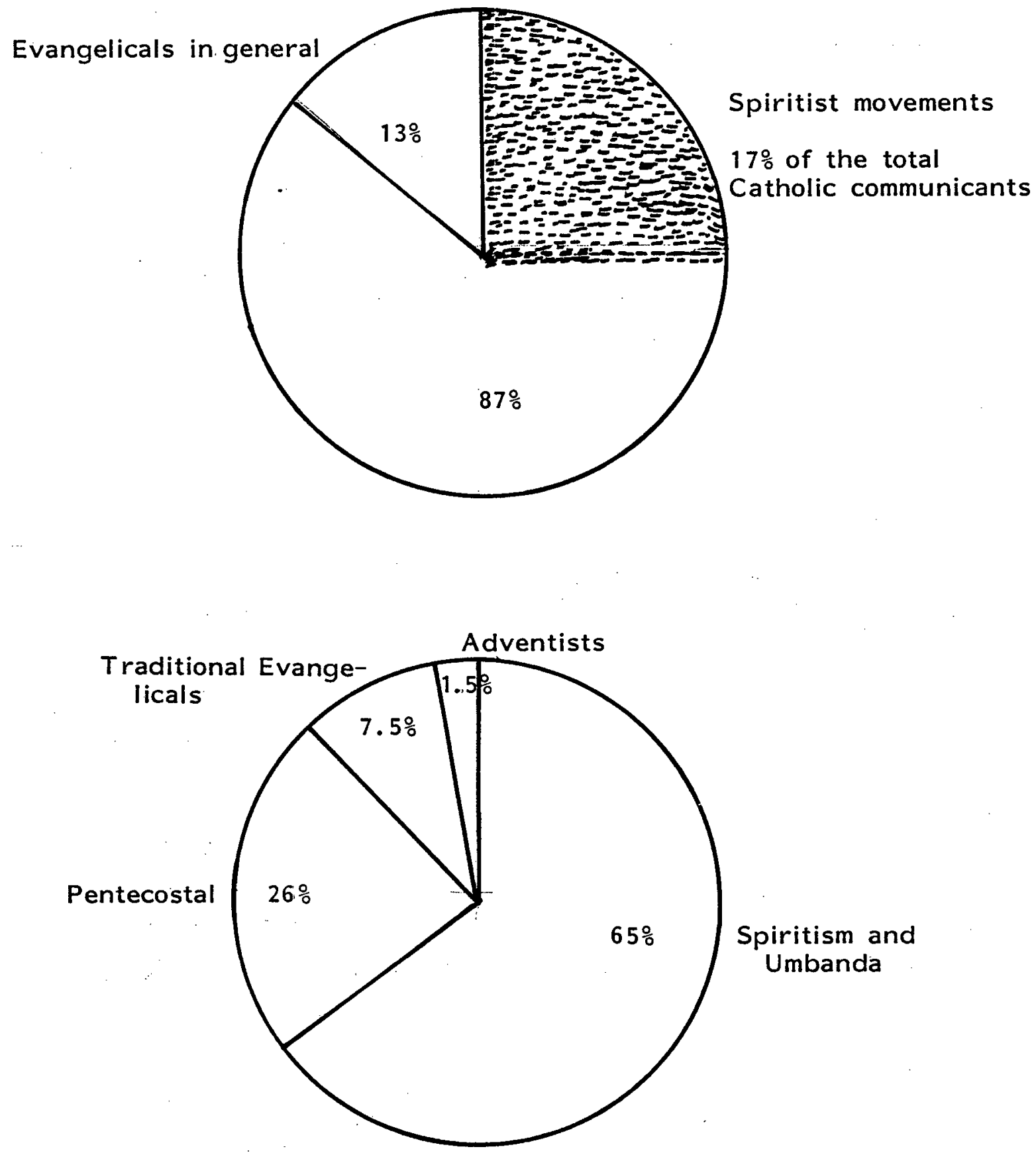

Figure 3. Above--Total population divided into Evangelical and Catholic groups featuring the penetration of the non-Christian religion into Catholicism Umbanda.

$$
\text { Below--Non-Catholic religions including Spiritism and }
$$


Bachmeyer, a young German seaman who some months before had become a Christian while in Liverpool, England. After persuading Bachmeyer to accept the SDA faith, Snyder instructed him in the art of selling books. Although not yet baptized, Bachmeyer soon began canvassing in Sao Paulo, where SDA books and papers, chiefly in German, found ready acceptance. ${ }^{1}$ Bachmeyer was a man of deep emotion and notable influence, and in his extensive missionary trips he spoke as an ambassador for Christ.

Among those who received the SDA message through the work of Bachmeyer, and as a result of reading the book Der Crosse Kampf (The Great Controversy) by Ellen G. White, were Guilherme Stein, Jr. and his family, Guilherme and Paulina Meyer, and Guilherme Stein III and his family. Guilherme Stein, Jr.., who had been a Methodist, abandoned his secular activities and later began teaching at the Curitiba International College and the Missionary School of Gaspar Alto, in the states of the South.

These pioneers were notable missionaries. They were examples for the generations destined to participate in their labor. They brought to Sao Paulo and to all Brazil a fervor to preach the gospel and to plant Adventist churches.

Early in 1895, Frank Henry Westphal, who had been working in Argentina, came to Sao Paulo accompanied by Stauffer, first colporteur to work in Sao Paulo. In the Piracicaba River. Westphal conducted the first baptismal ceremony in Brazil, in the state of Sao Paulo, about one hundred miles from the capital.

${ }^{1}$ Review and Herald 70 (October 24, 1893):665, 666 . 
Guilherme Stein, Jr., was the first Adventist of Brazilian birth to be baptized. Stein was a man of great culture. He soon translated into the Portuguese language the book, The Great Controversy, by Ellen G. White, and wrote an excellent book on the Sabbath and its theology.

God blessed the labors of those pioneers, but it was not easy to become a member of a Protestant Church. At that time just the mention of the terrible word crente (believer) scared men and women in every community. People believed that the devil took possession of the Protestants' bodies and that their feet were transformed into cloven hoofs. Sometimes the missionaries had to surprise the people who lived mainly in rural areas; they took off their shoes to prove that they were not messengers of sin so they could proceed in the preaching of the fervent gospel message.

The seeds sown by the pioneers germinated and these workers saw churches growing in many places before they returned to the United States.

\section{Laying the Foundations: 1908-1922}

The second period of SDA Church growth and development, 1908-1922, was characterized by the presence of German missionaries in Sao Paulo. Participation by foreign missionaries had a great influence on the growth of the SDA Church in southern Brazil. But the work of these missionaries took on different forms. While the American missionaries usually came to work for a period and then returned to the United States, the Germans remained permanently in Brazil. While American missionaries usually came to do administrative 
work, the Germans came to do evangelism in cities as well as rural areas.

The Adventist Church in Brazil has a debt of gratitude to the German missionaries who came to live, to preach, and to die with the Brazilian people. Today in the cemeteries of many cities such names as Kümpel, Streithorst, Ellers, Braun, Conrad, Hoyler, Graf, Schwantes, Lipke, Boehm, and many others are seen. The children of these early workers became part of the young church as members, pastors, teachers, and leaders.

It is well to note some of those who appeared on the scene during the second period, as far as the Adventist Church in Sao Paulo is concerned.

Huldrich F. Graf worked as an evangelist in south Brazil for twelve years, baptized about 1,400 converts, and organized more than a score of churches. Graf dreamed that the Church should have a publishing house and a school for training national pastors. Even with extremely limited means he started several schools that finally developed into the Adventist Brazil College in Sao Paulo. Graf died in 1946 in Brazil.

Another German missionary who did important work in Sao Paulo during this period was John Lipke. Like Graf, Lipke started as an evangelist, but understanding how decisive for the young Church in Brazil the training of its youth was, he accepted the responsibility of president of the Adventist Seminary in Sao Paulo while still superintending the Sao Paulo Mission. Lipke was an outstanding pioneer. He was teacher, preacher, administrator, and physician; he 
helped to establish the SDA publishing, educational, and medical work in Brazil. He spent the rest of his life in his mission field and died in Sao Paulo in $1943 .^{1}$ These two missionaries represent the great host of German missionaries who gave part of their lives to the Sao Paulo area and other parts of Brazil.

No one can fully understand the growth of the SDA Church in the second period of its development in Sao Paulo without understanding the relationship of two of its important institutions: the Adventist Seminary and the publishing house.

In 1907 land was bought in Sao Bernardo. The plan was to move the publishing house from the southernmost state of Brazil to Sao Paulo. This happened, and soon after Emilio Hoelzle reported in the Revista Mensal that a local church with fourteen members ${ }^{2}$ was organized. The first organized church in Sao Paulo was related to the publishing house. It is interesting to note that the first baptism resulted from the reading of the book The Great Controversy, which had been sold by a non-baptized colporteur. Thus, at its genesis, the SDA Church in Sao Paulo was related to the publication ministry. "With the help of God we started a work in the great capital of Sao Paulo," Jacob E. Koreker reported in the Revista Mensal by November 1908. He went on to say that six new converts were baptized and a Sabbath School was organized. Ricardo Sussmann was at that time working in Sao Paulo as an evangelist. At the conclusion

\footnotetext{
${ }^{1}$ Neufeld, pp. 526, 539, 654, 790, 1066, 1411.

${ }^{2}$ Emilio Hoelzle, "Missao Paulista," Revista Mensal (January, 1908), p. 7.
} 
of his report, Koreker added: "May the Lord bless His work in Sao Paulo and all over the world." And the Lord did.

Frederick W. Spies wrote years later that the city of Sao Paulo with its 350,000 inhabitants had a feast. It was the baptism of four people in the Tiete River. Soon after a new local church with about thirty members was organized. It was the organization of this first SDA church in the urban area of Sao Paulo that later became the Central Paulistana. It was the year 1912. 1

Missionary activities extended in many new directions. New workers came in. The Adventist Seminary prepared the first group of national workers and the first national worker was ordained to the ministry on April 4, 1920. But until 1920 the work depended largely on the activities of foreign missionaries and only a small percentage of the work was turned over to the national preachers.

The end of the second period was marked by a kind of prophetic anticipation. The Brazilian Adventist Seminary had its first graduation December 10, 19.22. On the following day the Paulista Mission had an assembly which opened with a motion that, in harmony with the recommendations of the South Brazil Union, the Paulista Mission should be organized as a Conference. This historical event happened on the basis of three facts: the SDA Church had 750 members in Sao Paulo, it had been supported by its own means, and there were several national workers. Of the five organized churches in the territory of the Paulista Mission, three were located in Sao Paulo city.

${ }^{1}$ F. W. Spies, Revista Mensal (August, 1912), p. 5. 
Progress and Expansion: 1923-1980

The third period of growth and development, 1923-1980, was one of progress and expansion of both the Church and its institutions.

In the secretary's report of the Sao Paulo Conference in 1929 is found the motion to help the Central and Vila Matilde churches to build their temples. Rodolpho Belz became the evangelist-pastor for the city of Sao Paulo.

The educational work had top priority in the administrative program, as can be seen by a statement in the report presented by the president Hagen: "A worker who does not organize a school where he is working is failing in his work. He is leaving a hole that will bring great loss to the Church." "At that time there were about 2,500 members in Sao Paulo city and the Church was growing at the rate of 10 percent yearly.

During the years 1923-1936 the missionaries turned over only the ecclesiastical responsibilities to their young; capable Brazilian pastors, but there is no record of traumatic feelings in the Adventist Church in Sao Paulo such as had occured among the Presbyterians at the beginning of the century. There were problems between missionaries and nationals, but the young Church overcame them through the help of men like Rodolpho Belz, who could mediate between his missionary and Brazilian colleagues until a modus operandi could be worked out on the basis of what was needed most in the propagation

'Floriano X. dos Santos, "Extraordinary Assembly Report of the Sao Paulo Conference of the SDA Church" (Sao Carlos, Brazil, 1977). Unpublished material. 
of the Advent message in Sao Paulo.

For various reasons, Adventists had not been willing to place Brazilians in important administrative positions at the head of the Church until 1936, when Rodolpho Belz was elected the president of Sao Paulo Conference. After this move the SDA Church gained remarkably in the development of its various institutions in Sao Paulo.

In 1941 Germano Ritter was elected president of the Sao Paulo Conference. He immediately founded an Adventist Hospital, the beginning of the medical work in the city.

The new evangelistic radio department was created under the direction of Moises Salim Nigri; and a home for elderly people was established--an attempt to put the Church in the context of social reality in Sao Paulo.

Administrative difficulties began to multiply, however. Ritter was a strong leader, but the Americans did not like his independent way of governing the Church. Again Rodolpho Belz entered the scene as a mediator. Germano Ritter was removed from his administrative position. Many people believed that Ritter gave the Church good institutions but that evangelism in Sao Paulo was neglected. This battle between the civilizers and the evangelizers will probably only have an end when Jesus comes. In this case, the evangelizers granted that the institutions were not necessary for planting churches in Sao Paulo; the civilizers tried to prove that hospitals, colleges, and buildings are evangelism as well as any other work.

In 1950 Joao Linhares became the new president of the Sao Paulo Conference. He revealed the same administrative tendency as Germano 
Ritter, but he emphasized much more evangelism in his program and kept the Church growing an average of 10 percent each year. It was not until the administration of Osvaldo Rodrigues de Azevedo in 1960 that the Adventists used a decisive plan that yielded a high growth rate in Sao Paulo.

In the sixties the large properties that were once expansive fazendas (farms) around the city of Sao Paulo were cut up into lots and new districts. Villages and sections of Greater Sao Paulo were filled with residences of many different types, providing room for the economically active population.

The administration of the Sao Paulo Conference took advantage of the low prices and bought more than fifty lots in those new districts. Today, on each one of those lots, there is a church. This factor, allied to a serious program of evangelism, gave the SDA Church in Sao Paulo a unique growth impulse.

Also, during Azevedo's administration Alcides Campolongo developed his evangelistic method for Sao Paulo. He established a joint program of public, radio, and television evangelism. His first experience was in the suburb of Casa Verde. As a result 135 new converts were baptized in one day in the central church of Sao Paulo. Thus, at the end of the sixties, Sao Paulo had 120 congregations and about 20,000 baptized members.

Roberto de Azevedo, a remarkable Christian and director of public relations of Adventists in Brazil, spent most of his time in Sao Paulo, working through the secular newspapers, radio, and television. He made such an impact on the urban population that the Adventist 
Church became an attractive religious institution in Sao Paulo. Once the director of the Globo, largest radio and television network in Brazil, was talking with some Adventist leaders. During his: talk he said:

"Roberto d'e Azevedo is the man who gave to your. Church the strong and good image that it enjoys all over the country."

The SDA Church membership grew so rapidly that there was no time to erect buildings. The people themselves rented houses and transformed them into churches, schools, and centers for social meetings. There were no pastors to shepherd the flocks and laymen arose as strong leaders. They were administrators, evangelists, teachers, and builders. To such a dynamic Church, the young population was attracted.

It is most impressive to note that in the seventies 70 percent of the new converts were young people under thirty years of age (see table 8). Wilson Sarli, the new president, directed his attention to the youth. Pathfinder Clubs were developed and by the end of 1976 there were about 3,000 juveniles involved in Pathfinder activities. An excellent youth camp was established, and evangelism was directed to the youth population.

TABLE 8

SDA CHURCH GROWTH COMPARATIVE BY AGE

\begin{tabular}{llllll}
\hline \hline Year & Up to 15 & $16-20$ & $21-30$ & $31-45$ & Above 45 \\
\hline $\begin{array}{l}1970 \text { to } \\
1979\end{array}$ & $45.7 \%$ & $9.3 \%$ & $15.4 \%$ & $17.9 \%$ & $9.7 \%$ \\
\hline
\end{tabular}


It seems that God called a special man for a special work in this setting. In 1972 Roberto Cesar de Azevedo became the director of the Education Department of the SDA Church in Sào Paulo and in his own way began to move the Church as never before toward an education program. In a short time new school buildings were erected and the number of Adventist young people attending the Adventist schools multiplied. By 1979 there were forty-five elementary schools in São Paulo, with 4,500 students enrolled. 1

Table 9 gives a comparison of population growth with SDA Church growth.

\section{TABLE 9}

COMPARISON OF POPULATION GROWTH WITH

SDA CHURCH GROWTH: 1970-1979

\begin{tabular}{lccc}
\hline \hline Entity & 1970 & 1979 & $\begin{array}{c}\text { Growth } \\
\text { Percentage }\end{array}$ \\
Sao Paulo & $7,921,496$ & $11,215,000$ & $40.2 \%$ \\
SDA Church & 16,200 & 35,680 & $118.3 \%$ \\
\hline
\end{tabular}

\section{Conclusion}

Doubtless the Adventist growth in Sao Paulo in the past, present, and future is linked to the rapid changes that take place in the Paulistan society, the strong Adventist leadership of consecrated pastors, and the dynamic action of the laypeople. But above all, it

1Relatório da $26^{\text {al }}$ Assembleia da Associacăo Paulista Leste (Sao Paulo, December, 1979), p. 12. Unpublished material. 
is due to the grace of God through whom all sinners can find forgiveness for their transgression. 


\section{CHAPTER V}

\section{ANALYSIS OF THE CHURCH GROWTH FINDINGS OF THE SEVENTH-DAY ADVENTIST CHURCH IN SAO PAULO}

\section{Introduction}

The growth of the Church in different places depends on specific methods used in the propagation of the gospel, combined with certain peculiarities of the people. Therefore, it is very important for the Church to develop an adequate outreach strategy, to relate itself in some way to the real characteristics of those who will hear the message.

The questionnaire ${ }^{1}$ used in the research of the SDA Church in Sao Paulo was designed to identify the sociological spectrum of the Paulistan population and to evaluate the strategies that have been used through the years. The first part of the questionnaire was designed to discover elements that help to understand the people; the second was planned to help the Church to sharpen its evangelistic methods in order to be more effective in its mission in the metropolitan area of Sao Paulo.

The purpose of this chapter is to present the findings of the research done among the sample congregations of Sao Paulo with some specific objectives:

\footnotetext{
${ }^{1}$ See appendix $A$.
} 
1. Provide a real understanding of the people reached by the Advent message in the last five years (1975-1979), and to determine how meaningful Adventism is to them.

2. Discover how the new members first learned about the SDA Church.

3. Determine the most significant factors in the member's decision to join the Church.

4. Identify hindrances that act as negative elements in the process of the propagation of the gospel.

The findings are presented with some discussion of their implications to the main objectives of the research. The analysis of the results of this church-growth study related to Sao Paulo's urban population primarily involved organizing the descriptive data into tables in relationship to the basic goals of the research. In some tables average values are used. The conclusions presented reflect the opinions of the sample of new converts who participated in the study.

\section{Sociological Factors and \\ Church Growth}

The Church is not planted in a vacuum. It is deeply rooted in the structure of mankind's necessities. The data obtained by this research shows that the new converts living in Sao Paulo are tied to the social components of the population as a whole.

It was shown in Chapter III of this study that Sao Paulo's urban population has specific social characteristics. The industrialization that brought about a rapid social movement prepared people to 
be more receptive to the preaching of the gospel. Eugene A. Nida affirms that the rate of church growth is often closely dependent upon the structure of the society in question. ${ }^{1}$ The results of this study on Church growth in Sao Paulo seems to support Nida's statement. The SDA Church can get better results in its evangelism if it pays attention to the real social aspects of the Paulistan population.

The first part of the survey instrument provided most of the sociological data reported below.

$\underline{\text { Sex }}$

There was 62.77 percent of the new converts who were female and 36.51 percent male. A significantly larger proportion of females than males was found in the SDA Church in Sao Paulo. This proportion is representative of the general movement of the evangelical churches in Sao Paulo. The city offers them the opportunity to serve in industry and as servants in middle- and upper-class homes having no trouble in keeping the Sabbath (see figure 4).

$\underline{\text { Age }}$

One of the obvious characteristics shown by the age profile was that the SDA Church's membership is highly concentrated in the young. Table 10 gives the distribution of new converts in five age categories. A clustering of ages in younger years is apparent. For example, 57.43 percent of the respondents were 10 to 30 years of age. It seems that the age of a group has a great

${ }^{1}$ Nida. "Culture and Church Growth," Church Growth and Christian Mission, McGavran, ed., p. 94. 


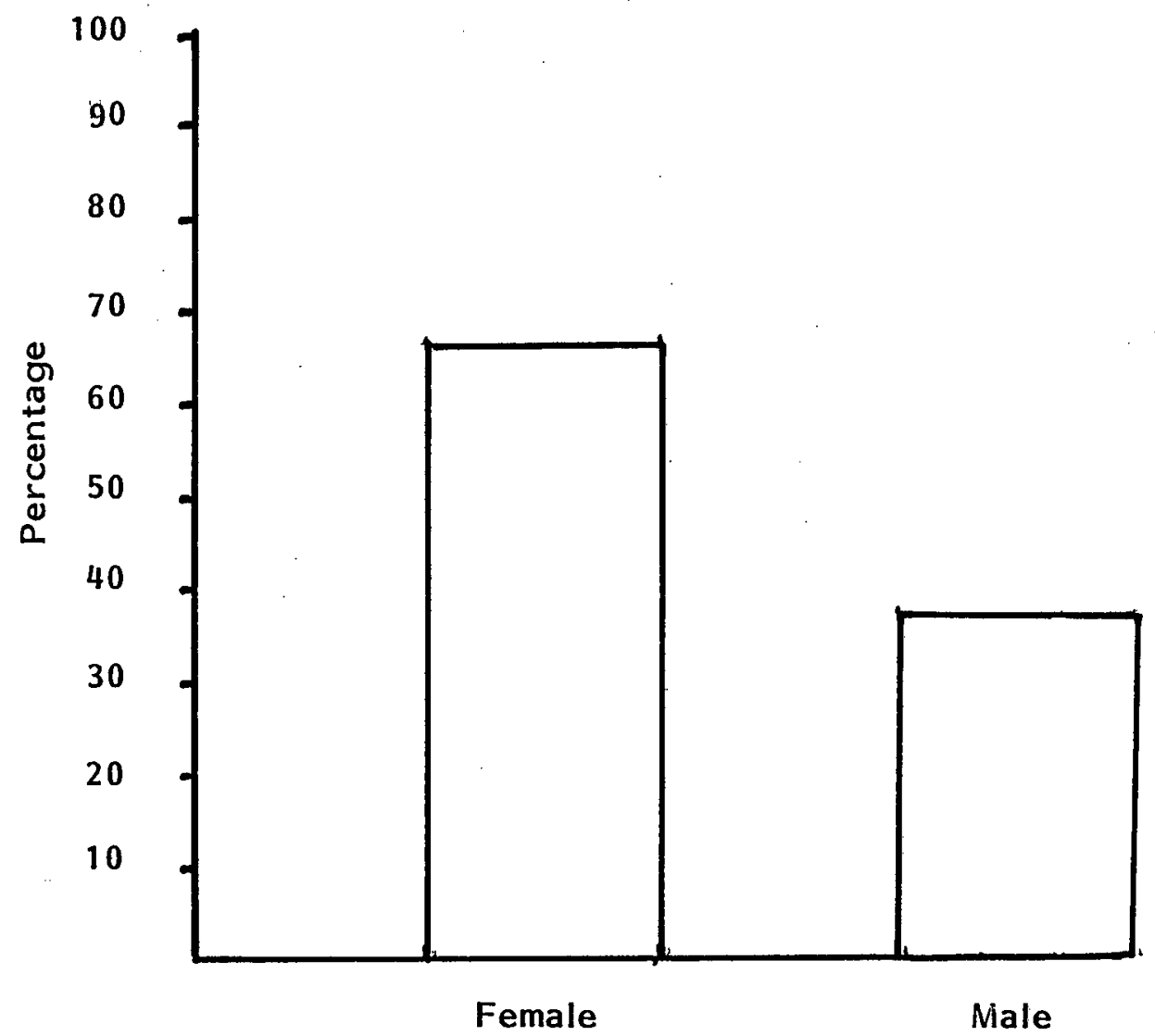

Figure 4. A male and female comparison of the total sample of new converts. 
TABLE 10

AGE OF THE NEW CONVERTS (1975-1979)

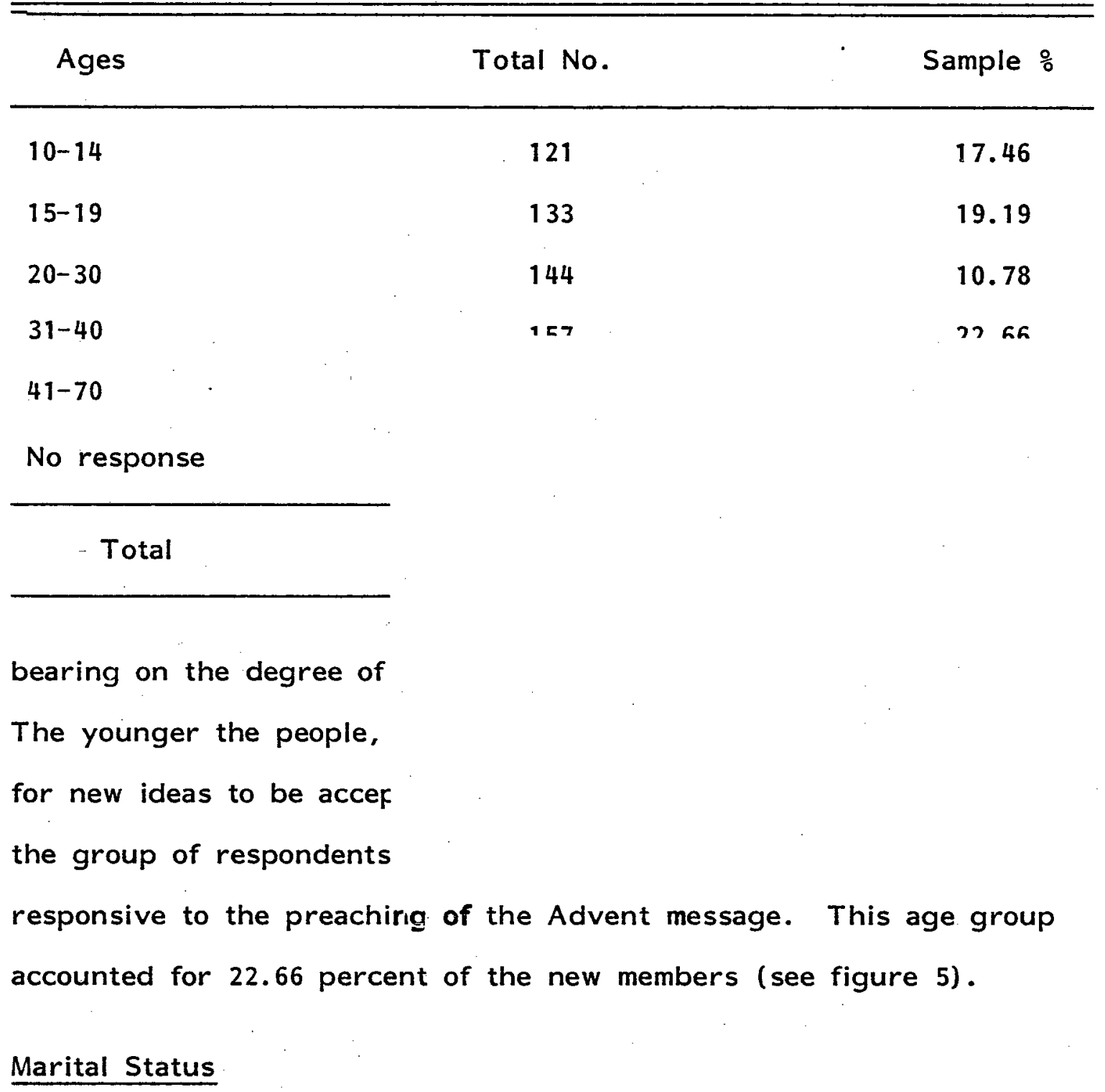

It would be quite natural to expect from the clustering of ages in the younger years that a predominant 53.68 percent of single people were among the new converts. From the total sample, 37.52 percent reported they were married, 1.88 separated, 1.73 widowed, and 3.90 engaged. The figures represent a fair picture of the Church in Sao Paulo (see table 11). 


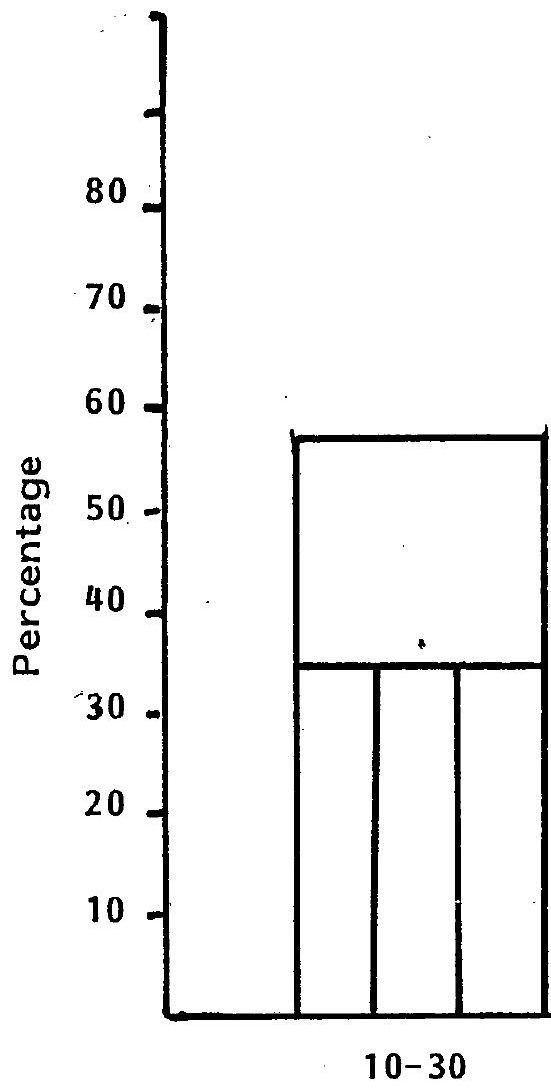

Male

Female

Figure 5. male and female. 
TABLE 11

MARITAL STATUS OF THE NEW CONVERTS

Total No.

Sample 응

\begin{tabular}{|c|c|c|}
\hline Married & 260 & 37.52 \\
\hline Separated & 13 & 1.88 \\
\hline Widowed & 12 & 1.73 \\
\hline Engaged & 27 & 3.90 \\
\hline Single & 372 & 53.68 \\
\hline No response & 9 & 1.30 \\
\hline Total & 693 & 100.00 \\
\hline
\end{tabular}

Formal Education

The formal education of the new converts oscillated in Sao Paulo churches from the incomplete elementary school to tertiary level. In the first and largest category, 47.62 percent reported not having completed the elementary school. Only 6.49 percent of the new converts reported having the professional qualification of the tertiary level of education (see table 12).

The degree of formal education found in a group of people, a church, or a population is an indicator of the possibilities of the group. The 47.62 percent in the first category indicates that the church participates in one of the real problems of the community. During recent years, the government has made significant efforts to help adults learn to read and write. The Adventist pastors generally haṽe been cooperating with this plan. 
TABLE 12

FORMAL EDUCATION OF THE NEW CONVERTS

\begin{tabular}{lcc}
\hline \hline Grade & Total No. & Sample \% \\
\hline Incomplete E. School level & 330 & 47.62 \\
Complete E. School level & 118 & 17.03 \\
Incomplete Secondary level & 108 & 15.58 \\
Complete secondary level & 69 & 9.96 \\
Tertiary level education & 45 & 6.49 \\
No response & 23 & 3.32 \\
\hline Total & 693 & 100.00 \\
\hline
\end{tabular}

\section{Occupational Status of New Converts}

Table 13 shows the occupational status of new converts. There were 69.40 percent of the new members who are wage-earners, 19.48 percent students, and only 8.23 percent are self-employed professionals. Some effort was made in this research to separate the new members into wage-earners and self-employed-worker categories to achieve one of the objectives of this study.

The first category in table 13 reports that 19.48 percent of the new members are students. But if a comparison is made with table 10 in which it is reported that 57.43 percent of the respondents were 10 to 30 years of age, it is obvious that a large percent of the young people are not having the apportunity to study. 
TABLE 13

OCCUPATIONAL STATUS OF THE NEW CONVERTS

\begin{tabular}{lcc}
\hline \hline Type of Occupation & Total No. & Sample \% \\
\hline Student & 135 & 19.48 \\
Clerk & 93 & 13.42 \\
Skilled wage-earner & 164 & 23.67 \\
Self-employed workers & 57 & 8.23 \\
Unskilled wage-earner & 226 & 32.61 \\
No response & 18 & 2.60 \\
\hline & 693 & 100.00 \\
\hline
\end{tabular}

Total Personal Income

Table 14 reports the new converts' total personal income. A heavy representation occurs in the lower income levels; 44.46 percent of the respondents reported less than $\mathrm{Cr} \$ 15,000.00$ per month (nearly US $\$ 200.00$ ). Only 6.20 percent of the new members reported $\mathrm{Cr} \$ 50,000.00$ or more monthly (about US $\$ 700.00$ ). (See figure 6.)

Size of "Home" Community

The official statistics of the government of Sao Paulo reports that 45 percent of the population was not born in Sao Paulo. In this research the new members were asked to indicate the size of community in which they lived before coming to Sao Paulo. This item was intended to discover how much the Adventist Church appeals to migrants who lost their traditional social group when moving to Sao Paulo. There 
TABLE 14

MONTHLY INCOME OF THE NEW CONVERTS

\begin{tabular}{lcc}
\hline \hline Income & Total No. & Sample \% \\
\hline Under Cr $\$ 5,000,00$ & 126 & 18.18 \\
$\$ 5,000.00-\$ 15,000.00$ & 184 & 26.55 \\
$\$ 15,000.00-\$ 25,000.00$ & 157 & 22.66 \\
$\$ 25,000.00-\$ 50,000.00$ & 131 & 18.90 \\
$\$ 50,000.00$ or more & 43 & 6.20 \\
No response & 52 & 7.50 \\
\hline Total & 693 & 100.00 \\
\hline
\end{tabular}

were 24.10 percent of the new members who were rural-urban migrants, 24.25 percent were reared in small cities of the interior, 24.10 percent lived in middle-sized cities during the previous years, and 21.07 percent grew up in a large city (see table 15 ).

\section{Geographical Region of Origin}

For the purposes of this research the data in table 16 are important. Brazil is made up of five specific geographical regions: North, that comprises the states of Amazon, Para, and Territories; Center-west, Mato Grosso and Goias; Northeast, composed of nine small states; Southeast, which has the highest demographic rate; and South (see figure 7). This research found that most of the new members came from three of those five geographical regions. Those areas are states with a shifting and highly mobile population. Thus 


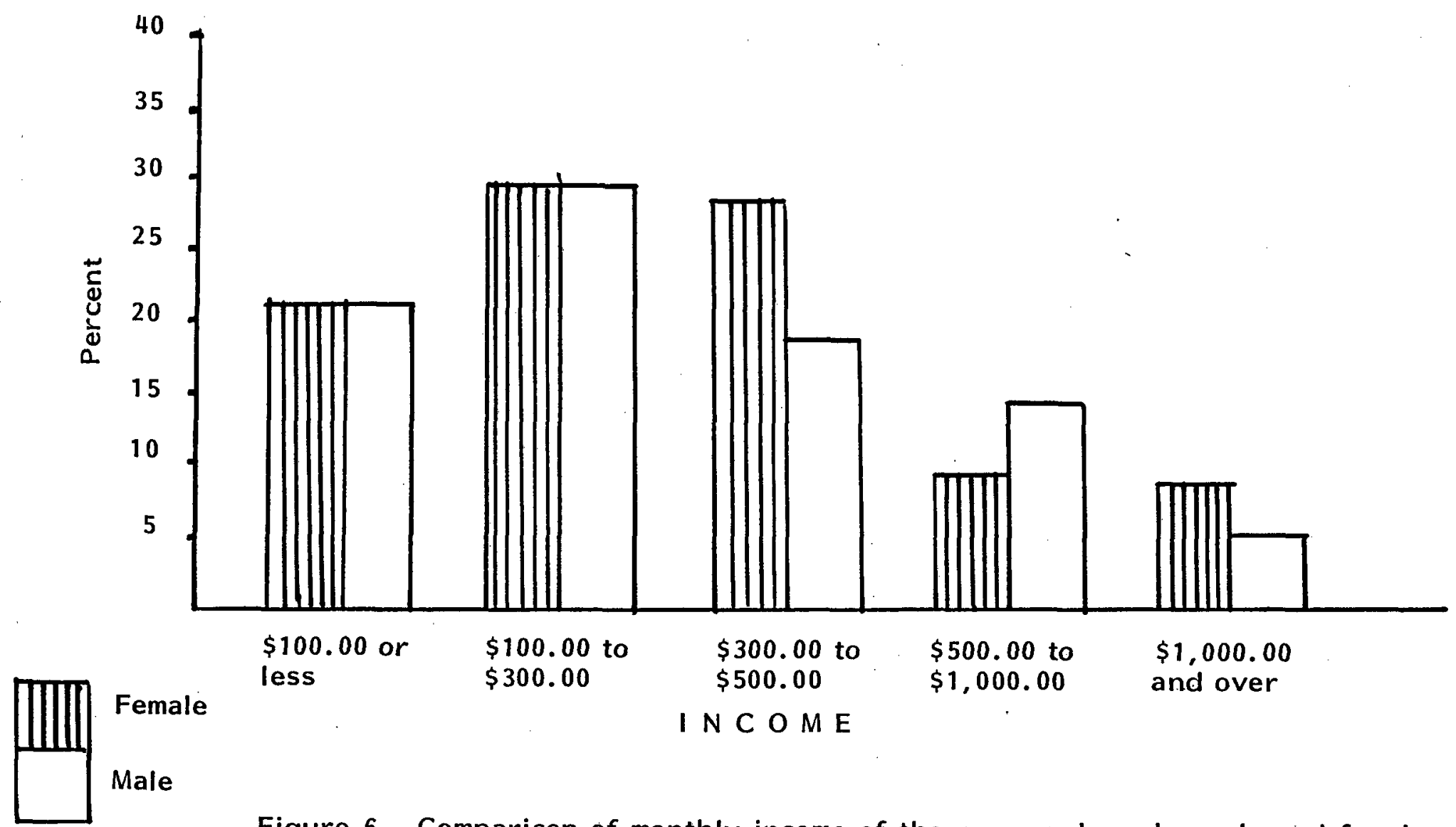

Figure 6. Comparison of monthly income of the new members by male and female. 
TABLE 15

COMMUNITY SIZE FROM WHICH THE NEW CONVERTS MIGRATED TO SAO PAULO

\begin{tabular}{lcc}
\hline Size & Total No. & Sample \\
\hline Rural area & 167 & 24.10 \\
$5,000-15,000$ inhab. & 85 & 12.27 \\
$15,000-50,000$ inhab. & 83 & 11.98 \\
$50,000-500,000$ inhab. & 167 & 24.10 \\
500,000 or more inhab. & 146 & 21.07 \\
No response & 45 & 6.49 \\
\hline Total & 693 & 100.00 \\
\hline
\end{tabular}

TABLE 16

GEOGRAPHICAL REGION OF ORIGIN OF THE NEW CONVERTS

\begin{tabular}{lcc}
\hline \hline Region & Total No. & Sample \% \\
\hline North & 25 & 3.61 \\
Center-west & 22 & 3.17 \\
Northeast & 90 & 12.99 \\
Southeast & 412 & 59.45 \\
South & 121 & 17.46 \\
No response & 23 & 3.32 \\
\hline Total & 693 & 100.00 \\
\hline
\end{tabular}


59.45 percent of the new converts reported they came from the interior of Sao Paulo state itself, and Minas Gerais and Rio de Janeiro states; 12.99 percent came from the Northeast; and 17.46 percent of the new members came from the South (see figure 7).

\section{Conclusion}

Many Christians, including Adventists, do not feel comfortable with the idea that conversion and practical life are in general interrelated elements. They prefer to see in the conversion process just the divine miracle of the transforming power of the gospel without any relationship to the environment reality. But it is necessary to remember that conversion does not happen in a vacuum. The gospel is to be preached to real people--people living in real situations and facing real problems. Therefore the study of the socio-economic setting of the Sao Paulo population is very important for the objectives of this research.

\section{Religious Factors and Church Growth}

The Seventh-day Adventist Church understands its mission as a peculiar mission on the earth. The Adventist Church exists for the primary purpose of proclaiming the everlasting gospel to all the people, with the aim of obtaining decisions for Jesus Christ. Jesus himself commissioned the Church to teach all nations and to baptize everyone who accepts the gospel. There are people that need the gospel in the pagan world as well as in the so-called Christian churches. The religious background can help in the way a certain group reacts when hearing the Adventist message. Therefore, for the purpose 
BRAZIL--GEOGRAPHICAL REGIONS

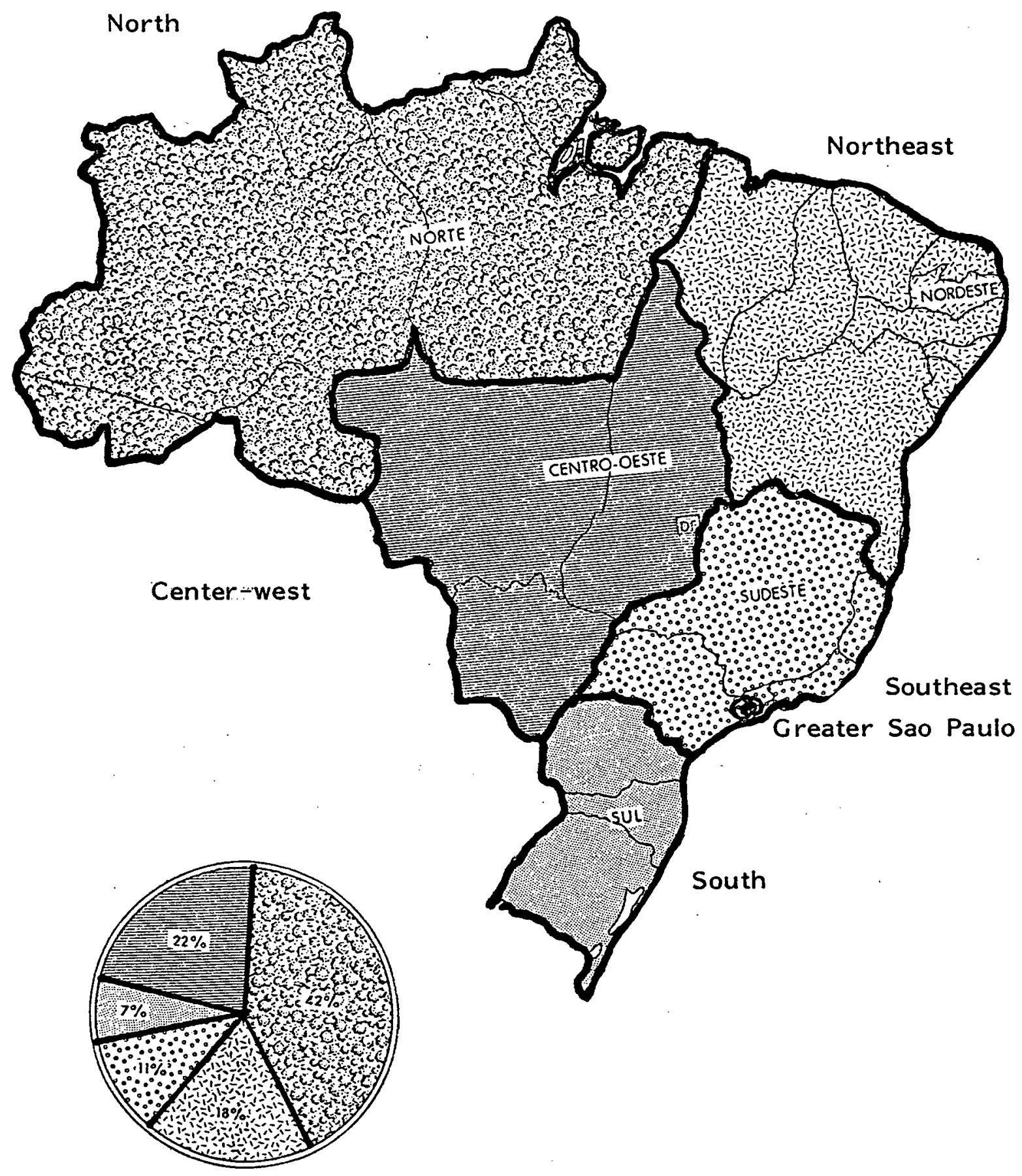

Source: IBGE

Figure 7. Brazil--Geographical Regions. 
of this study it is important to determine how the previous religious experience of the respondents affected their decision to join the SDA Church.

The Influence of Previous Religion

Table 17 indicates the influence of previous religious experience in the life of the new members. The predominant response, 48.92 percent, of the respondents indicated that they felt religion had great influence in their lives. Another 35.21 percent reported that religion had a moderate influence on them, and 7.07 percent said that religion had almost no influence on their lives. Only 5.34 percent reported religion had absolutely no influence on their previous experience. Thus the overwhelming majority of New Adventist converts have had a prior religious orientation.

\section{TABLE 17}

THE INFLUENCE OF PREVIOUS RELIGION IN THE LIFE OF THE NEW CONVERTS

\begin{tabular}{|c|c|c|}
\hline Type of Influence & Total No. & Sample \% \\
\hline Great & 339 & 48.92 \\
\hline Moderate & 244 & 35.21 \\
\hline Almost nothing & 49 & 7.07 \\
\hline Nothing at all & 37 & 5.34 \\
\hline No response & 24 & 3.46 \\
\hline Total & 693 & 100.00 \\
\hline
\end{tabular}


Previous Religious Affiliation

Of the total sample only 5.63 reported that they did not have previous religious affiliation. The most frequently reported previous denominational affiliation was Catholics--74.60 percent of the new converts. Other previous religious affiliations reported were: (1) Protestants, ${ }^{1} 5.48$ percent; Pentecostals, 7.22 percent; and Spiritists, 4.76 percent (see table 18).

TABLE 18

PREVIOUS RELIGIOUS NON-SDA AFFILIATION

\begin{tabular}{lcc}
\hline \hline Religion & Total No. & Sample \% \\
\hline Roman Catholic & 517 & 74.60 \\
Protestants & 38 & 5.48 \\
Pentecostals & 50 & 7.22 \\
Spiritists & 33 & 4.76 \\
No religion & 39 & 5.63 \\
No response & 16 & 2.31 \\
\hline \multicolumn{1}{c}{ Total } & 693 & 100.00 \\
\hline
\end{tabular}

In his study, "The Voice of Prophecy and Conversion in Sao Paulo," Roberto Cezar de Azevedo points out that such statistics do not represent the true situation. He claims that the Catholic people understand that it is enough to be baptized and nothing more to belong to

${ }^{1}$ Protestants included Baptists, Presbyterians, Lutherans, and Methodists. Those are the churches which have significant representation in Sao Paulo. 
the church. People call themselves Catholics, but they do not practice religious activities. ${ }^{1}$ In any case, only 5.63 percent of the respondents reported having no previous religious affiliation.

\section{The Outreach Strategy and Church Growth}

The next section of the questionnaire was concerned with the effectiveness of methods and elements in the outreach strategy used by the SDA Church in Sao Paulo City.

Initial Contact with Adventists through Personal Influence

Table 19 shows that 44.59 percent of the new members first learned about the Adventist Church through a family member or relative. Friends were the second most frequently reported initial contact with the church. These data indicate that 74.32 percent of the new converts were more readily influenced by relatives and friends. The rest of the sample divided itself among pastor, evangelist, and Bible instructor.

Comparing tables 20 and 21 , it is noted that the new female converts reported to have received first information about the Adventists more by relatives and friends than new male converts. But in both cases the fact remains that relatives and friends are the first source of information about the SDA Church for the new converts in general.

Analyses of tables 19,20 , and 21 indicate that the new members

${ }^{1}$ Roberto C. de Azevedo, A Voz da Profecia e a Conversao no Estado de Sao Paulo (Universidade de Sao Paulo, Escola de Comunicacoes e Artes, 1978), pp. 9, 10. 
TABLE 19

SOURCE FROM WHICH THE NEW CONVERT FIRST

RECEIVED INFORMATION ABOUT THE

SDA CHURCH

\begin{tabular}{lcc}
\hline \hline Person & Total No. & Sample \\
\hline Relatives & 309 & 44.59 \\
Pastor & 51 & 7.36 \\
Friends & 206 & 29.73 \\
$\begin{array}{l}\text { Bible correspondence } \\
\text { Course }\end{array}$ & 41 & 5.99 \\
Radio and TV & 54 & 7.79 \\
No response & 32 & 4.62 \\
\hline \multicolumn{1}{c}{ Total } & 693 & 100.00 \\
\hline
\end{tabular}

TABLE 20

SOURCE FROM WHICH THE NEW MALE CONVERTS FIRST RECEIVED INFORMATION ABOUT THE SDA CHURCH

\begin{tabular}{lcc}
\hline Person & Male No. & Sample $\%$ \\
\hline Relative & 110 & 43.48 \\
Pastor & 19 & 7.51 \\
Friend & 81 & 32.02 \\
$\begin{array}{l}\text { Correspondence Bible } \\
\text { Course }\end{array}$ & 15 & 5.93 \\
Radio and TV & 20 & 7.91 \\
No response & 8 & 3.16 \\
\hline \multicolumn{1}{c}{ Total } & 253 & 100.00 \\
\hline
\end{tabular}


TABLE 21

SOURCE FROM WHICH NEW FEMALE CONVERTS

FIRST RECEIVED INFORMATION ABOUT

THE SDA CHURCH

\begin{tabular}{lcc}
\hline \hline Person & Female No. & Sample \% \\
\hline Relative & 119 & 45.75 \\
Pastor & 32 & 7.36 \\
Friends & 124 & 28.51 \\
$\begin{array}{l}\text { Correspondence Bible } \\
\text { Course }\end{array}$ & 26 & 5.98 \\
Radio and TV & 32 & 7.36 \\
No response & 22 & 5.06 \\
\hline \multicolumn{1}{c}{ Total } & 355 & 100.00 \\
\hline
\end{tabular}

most often reported that a lay person was the initial contact with the Church. Evidently, an evangelistic method with a personal component provides a more significant impact than does a non-personal method.

Most Influential Factor on Decision to join the SDA Church

The most vital question in the questionnaire asked new members to paint out the most influential factor that helped them to join the Adventist Church. The same contacts named in the prior question-the source from which the new converts first received information about the SDA Church--were mentioned here. The distribution of the response may be seen in tables 22, 23, and 24. Again, the relatives and friends were the most important elements in helping the new 
TABLE 22

THE MOST INFLUENTIAL FACTOR IN THE DECISION TO JOIN THE SDA CHURCH

\begin{tabular}{|c|c|c|}
\hline Personal Influence & Total No. & Sample 응 \\
\hline Relatives & 159 & 22.94 \\
\hline Pastor & 93 & 13.42 \\
\hline Friends & 147 & 21.21 \\
\hline $\begin{array}{l}\text { Bible corresponden } \\
\text { Course }\end{array}$ & 69 & 9.96 \\
\hline Radio and TV & 43 & 6.20 \\
\hline No response & 182 & 26.26 \\
\hline Total & 693 & 100.00 \\
\hline
\end{tabular}

TABLE 23

THE MOST INFLUENTIAL FACTOR FOR PROTESTANTS TO JOIN THE SDA CHURCH

Total No.

17

5

9

3

7.89

course

Radio and TV

2

2

Sample 응

44.89

13.16

23.68

No response

Total

100.00 
TABLE 24

THE MOST INFLUENTIAL FACTOR FOR CATHOLICS

TO JOIN THE SDA CHURCH

\begin{tabular}{lcc}
\hline \hline Factor & Total No. & Sample \\
\hline Relatives & 242 & 46.81 \\
Pastor & 31 & 6.00 \\
Friends & 159 & 30.75 \\
$\begin{array}{l}\text { Bible correspondence } \\
\text { C ourse }\end{array}$ & 29 & 5.61 \\
Radio and TV & 40 & 7.74 \\
No response & 16 & 3.09 \\
\hline \multicolumn{1}{c}{ Total } & 517 & 100.00 \\
\hline
\end{tabular}

converts join the SDA Church. Analysis of tables 23 and 24 indicates that the same trend was shown by the new converts coming from Catholic and Protestant churches.

Outreach Agencies and Decisions

From a list of five outreach agencies the new members were asked to select the one that had the greatest influence on their decision to become Seventh-day Adventists. Bible studies with the aid of a film-strip collection named Tesouros da Fe (Treasures of Faith) was reported by 26.55 percent of the new members as the strategy which had the greatest influence upon their decision. Lay evangelism meetings were reported as having the greatest influence by 22.51 percent. These were followed by the Voice of Youth evangelistic program, 
public evangelism, and radio and TV programs (see table 25).

Throughout this research, the laity seems to be the most effective agency in the growth of the SDA Church in Sao Paulo. The sum of the three last items in table 25 indicates that 65.80 percent of the new members reported that the laity was the most effective agency in their decision.

TABLE 25

OUTREACH AGENCIES THAT HELPED MORE NEW CONVERTS TO JOIN THE SDA CHURCH

\begin{tabular}{lcc}
\hline \hline Agency & Total No. & Sample \% \\
\hline Radio and TV & 17 & 2.45 \\
Public evangelism & 88 & 12.70 \\
Lay evangelism & 156 & 22.51 \\
Tesouros Da Fe & 184 & 26.55 \\
Voice of Youth & 116 & 16.74 \\
No response & 132 & 19.05 \\
\hline Total & 693 & 100.00 \\
\hline
\end{tabular}

Mass Media Communication

The distribution of Mass Media factors which the new members chose as having influence on their decision to join the Church are found in table 26. The three items with the highest percentage of response were: Faith for Today (21.07 \%), Voice of Prophecy (16.45\%), and Light in the Way $(8.23 \%)$. Yet mass media in the total sample was reported as having only 5.26 percent of the influence. 
TABLE 26

RADIO, TELEVISION, AND TELEPHONE AND THEIR

INFLUENCE IN BRINGING NEW MEMBERS TO

THE SDA CHURCH

\begin{tabular}{lcc}
\hline Program & Total No. & Sample \\
\hline Faith for Today & 146 & 21.07 \\
Voice of Prophecy & 114 & 16.45 \\
Light in the Way & 57 & 8.23 \\
Telepaz ${ }^{1}$ & 18 & 2.60 \\
Other & 97 & 14.00 \\
No response & 261 & 37.66 \\
\hline Total & 693 & 100.00 \\
\hline
\end{tabular}

\section{SDA Publications}

Table 27 shows that the Adventist newspaper (Jornal Adventista) published during the period covered by this survey $(1975-1978)$ was quite effective as an outreach element. There was 16.44 percent of the new converts who reported that the Jornal Adventista was a help in influencing their joining the SDA Church; 8.95 percent said that the Folhetăo (a special literature campaign) was helpful, and 8.80 percent named Adventist magazines in general.

Bible-Study Method

Among the several methods of giving Bible studies, 23.23

percent of the new converts reported that Bible studies at home were most helpful; 21.07 percent named the Sabbath School classes; 19.34

${ }^{1}$ SDA Telephone Counseling Service. 
TABLE 27 .

ADVENTIST MAGAZINES AND NEWSPAPERS AND

THEIR PERCENTAGE OF INFLUENCE ON

NEW CONVERTS

\begin{tabular}{lcc}
\hline \hline & Total No. & Sample \\
\hline Magazines & 61 & 8.80 \\
Folhetao & 62 & 8.95 \\
Adventist Review & 68 & 9.81 \\
Jornal Adventista & 116 & 16.74 \\
Other & 132 & 19.05 \\
No response & 234 & 36.65 \\
\hline Total & 693 & 100.00 \\
\hline
\end{tabular}

percent mentioned pastoral Bible studies; and 8.66 percent baptismal classes at the church (see table 28).

Reasons for Becoming Adventists

Table 29 shows that the church is stressing a legalistic view of some doctrines included in the evangelistic program. The new converts were asked to indicate which features attracted them to the Church. Among the total sample, 32.61 percent said that they were looking for salvation, 19.62 percent became Adventists because of the teaching on the Law, 18.04 percent because they needed God's love, 16.45 percent felt it was the true Church of God, and only 6.64 percent joined to have friends. 
TABLE 28

BIBLE STUDY METHODS THAT MOST HELPED

NEW CONVERTS MAKE DECISIONS

\begin{tabular}{lcc}
\hline \hline Method & Total No. & Sample \\
\hline $\begin{array}{l}\text { Bible correspondence } \\
\text { School }\end{array}$ & 109 & 15.76 \\
Bible study at home & 161 & 23.23 \\
Sabbath School class & 146 & 21.07 \\
Pastor's Bible study & 134 & 19.34 \\
Baptismal class & 60 & 8.66 \\
No response & 83 & 11.98 \\
\hline
\end{tabular}

TABLE 29

REASONS THAT LED THE NEW CONVERTS TO JOIN THE SDA CHURCH

Total No.

Sample :

\begin{tabular}{lcc}
\hline To find salvation & 226 & 32.61 \\
To obey the Law & 136 & 19.62 \\
To have friends & 46 & 6.64 \\
To feel God's love & 125 & 18.04 \\
To be in the true Church & 114 & 16.45 \\
No response & 46 & 6.64 \\
\hline Total & 693 & 100.00 \\
\hline
\end{tabular}


The Most Attractive Element

in the SDA Church

From a list of five elements that characterize the SDA Church in Sao Paulo, the new members were asked to indicate the most attractive ones. Table 30 shows that the majority (41.13\%) was very much impressed by the SDA doctrines, 19.19 percent expressed high attraction to the E. G. White books, and 12.99 percent referred to the presentation of Jesus Christ as a chief attraction.

TABLE 30

THE MOST ATTRACTIVE ELEMENT IN THE SDA COMMUNITY FOR THE NEW CONVERTS

\begin{tabular}{lcc}
\hline \hline & Total No. & Sample \% \\
\hline Doctrines & 285 & 41.13 \\
Friendship & 56 & 8.08 \\
Jesus Christ & 90 & 12.99 \\
E. G. White books & 133 & 19.19 \\
Healthful Living & 66 & 9.52 \\
No response & 63 & 9.09 \\
\hline \multicolumn{1}{c}{ Total } & 693 & 100.00 \\
\hline
\end{tabular}

\section{Conclusion}

The information in this study is offered not as numerical proof that one method is superior to another but as an indication of the relative effectiveness of outreach strategies that have been used by the SDA Church in Sao Paulo. The data generated by the research 
reported measurable influences upon the new converts' decision to join the Church. Such a report cannot deal with the subjective activity of the Holy Spirit, but His presence and authority in the whole process of the Church itself is always implied. 


\section{CHAPTER VI}

\section{SUMMARY, CONCLUSIONS, AND \\ RECOMMENDATIONS}

This chapter is a summary of the more significant findings of a study on church growth in the Seventh-day Adventist Church in Greater Sao Paulo, Brazil. It also includes some conclusions derived from the findings and subsequent recommendations.

The purpose of the study was to discover which elements have been most influential in the decisions for Christ made by recent converts and, with the help of this information, to suggest some adequate evangelistic elements that will further enhance church growth in the SDA Church in Sao Paulo, Brazil.

\section{Summary}

The information collected by this research was organized under the limitations of five objectives:

Objective 1--To prepare a brief socio-economic description of the new converts of the SDA Church in the metropolitan area of Sao Paulo in the last five-year period (1975-1979).

It was found that about 34 percent of the respondents were male and 63 percent female. Almost 54 percent of the new members baptized in the last five years were between 10 to 30 years of age, and 35 percent were 10 to 19 years of age. Approximately 54 percent 
of the new converts were single and 38 percent married. There were 70 percent who reported that they were wage-earners, 19.48 percent students, and only 8.23 percent were self-employed. Almost 50 percent of the new members had attended grade school, but only 6.5 percent reached the tertiary level of formal education. About 20 percent of the new members had a monthly income of $\mathrm{Cr} \$ 5,000.00$ (nearly US $\$ 70.00$ ) and only 6.20 percent earned about $\mathrm{Cr} \$ 50,000.00$ (nearly US $\$ 700.00)$. Almost 50 percent of the new converts were reared in a community with less than 50,000 inhabitants. About 60 percent were migrants from the geographical region named Southeast, of which Sao Paulo is a part, and 13 percent came from the Northeast of Brazil. Objective 2--To discover how previous religious affiliation affected the new convert and from what main religious groups they came.

The majority of the new members reported that their previous religion had an accentuated influence in their lives; only 5 percent said that it had no influence at all. The previous religious affiliation of 75 percent of the new converts was Catholic, 7 percent Pentecostal, 5.5 percent traditional Protestant, and 4.70 percent Spiritist.

Objective 3--To indicate how initial contact with Adventism was made and what influenced most the new members to join the SDA Church in Creater Sao Paulo.

The majority of the new converts (45\%) reported that their initial contact with the SDA Church was through a family member or relatives. The second most frequently reported initial contact $(29.73 \%)$ was friends. The percentage was almost the same for both male and female converts. - Of the new members, almost 23 percent indicated 
that relatives had the greatest influence on their decision to join the SDA Church, and 21.21 percent indicated that friends had such an influence. The pastor's influence was reported by 13.42 percent of the converts. The Bible Correspondence School, radio, and TV programs had only a minor influence on the new converts' decision to join the SDA Church in Sao Paulo.

Objective 4--To determine which outreach agency is most effective as an evangelistic tool in reaching the urban population of Sao Paulo.

The laity was the single strongest agency which influenced people to join the Church. About 49 percent of the respondents reported that the lay agencies were most effective in bringing them to the SDA Church; these were followed by public evangelism. Among the several mass media outreach programs, Faith for Today was ranked first, the Voice of Prophecy second, and Light in the Way third. The Jornal Adventista was the most effective publication for outreach activities. Among the several methods of Bible study, both the method of going to the homes of interested persons and the traditional Sabbath School class were reported to be very effective.

Objective 5--To inquire what has been the emphasis given by the SDA Church in its evangelism in Sao Paulo.

About 41 percent of the new converts reported that they were attracted by the doctrines of the Adventists. Only 13 percent found the Adventist understanding of Jesus Christ the most attractive tenet of the Church. The rest of the responses ranged from friendship and healthful living, and the Spirit of Prophecy. 


\section{Conclusions and Recommendations}

\section{Conclusion 1}

The population of Greater Sao Paulo presents specific characteristics of a community built up on the rapid process of industrialization that took place over the last twenty years. Religion and religious institutions should have a functional role in the adjustment process of the migrants and should help them find a personal community to replace what they lost when they left the peculiar social setting in which they were reared.

Recommendation. As the Seventh-day Adventist Church develops its evangelistic strategies to promote future church growth, it should take into account the sociological characteristics of the population and stress the social attractiveness of the Adventist Church as a living community. The application of sociological insights to the affairs of the Adventist denomination has been generally neglected in Sao Paulo. The advocates of church growth strongly believe and have demonstrated that knowledge of the social structure of a given population greatly aids church growth. The SDA Church is made up of individual human beings taking part in the society at large. Therefore, just as the Church can influence the society, the attitudes of the society toward the Church can promote or hinder its activities. It seems that Adventist growth in Sao Paulo is very much dependent upon our understanding of sociological factors within the societies in which the outreach strategy is going to be applied.

By observing the constituency of the churches in Sao Paulo 
metropolitan areas it seems that some of the principles developed by the church-growth school of thought are very much applicable. It is very intersting to note that usually migrants coming from certain regions of Brazil show preference for living in a specific suburb where migrants from their own region are living. This fact leads one to consider some of the distinctive principles presented by McGavran in his book The Bridges of God. ${ }^{1}$

The homogeneous unit principle has doubtless been one of the factors that helped the SDA Church grow in Sao Paulo. Tetsunao Yamamori, quoting McGavran, says that the general population may be compared to a mosaic. Each piece of the mosaic is a society, a homogeneous unit. It has its own way of life, its own standards, degree of education, self-image, and places of residence. ${ }^{2}$ McGavran stated such a principle simply by saying, "People like to become Christians without crossing racial, linguistic, or class barriers." ${ }^{3}$. What is meant is further characterized by Peter Wagner's definition: "A homogeneous unit is simply a group of people who consider each other to be 'our kind of people. "' 4 The population of Sao Paulo is gradually becoming a great homogeneous society but there are today different groups which present peculiar characteristics that may be considered as

${ }^{1}$ Donald A. McGavran, The Bridges of God (New York: World Dominion Press, 1955), pp. 107-108.

${ }^{2}$ Tetsunao Yamamori and E. Le Roy Lawson, Introducing Church Growth (Cincinnati, Ohio: A Division of Standard Publishing, 1975), P. 80.

${ }^{3}$ Donald A. McGavran, Understanding Church Growth (Grand Rapids: William B. Eerdmans, 1970), p. 17.

${ }^{4}$ C. Peter Wagner, Your Church Can Be Healthy (Nashville, Tennessee: Abingdon, 1979), p. 17. 
homogeneous units. The homogeneous unit principle is a significant church-growth issue that should be considered in the development of an evangelistic strategy in Sao Paulo. When the homogeneous unit receives recognition, respect, and resources, there is evidence to believe that it can strengthen the life of the church. Although the homogeneous unit principle presents a high regard for human diversity its goal is to reach people and promote unity. For all members at last will be parts of the same Body.

There is a natural link from the homogeneous-unit concept to the people-movement principle that has been developed. In the more educated societies in Sao Paulo, each person is encouraged to make decisions on his or her own without consulting others. This cultural trait is strengthened through the breakdown of the wider family into independent nuclear units and through great mobility that characterizes a growing industrial city like Sao Paulo. The outreach strategy which works best in this kind of social structure is one which seeks individual conversions. But the social structure of a significant part of the population in Sao Paulo has its roots in African tradition.

This is why Umbanda appeals to the Paulistan as it was mentioned in Chapter IV. These people have solidarity and interdependence. Decisions are not usually made without consulting others. Evangelism in societies of this kind, to be effective, must aim at winning social units by encouraging internal discussion and informal votetaking until the whole group is won for Christ. It is true that the emphasis of the Adventist evangelism in Sao Paulo has been individual conversions. But it seems that such a procedure has been one of the 
elements responsible for a high rate of apostasy among the new converts in Sao Paulo.

There is no doubt that conversion requires personal repentance and faith commitment, and genuine conversion is essential if Adventism is to be true to itself. McGavran insists that "Conversion means participation in a genuine decision for Christ. . . The individual decisions within a people movement exhibit all these marks." ${ }^{7}$ The Bible clearly validates the fact that conversion can be accepted as genuine irrespective of the number of people that experience it simultaneously. But it seems that the people-movement principle does not invalidate the Bible docirine of conversion. The group only facilitates the process of decision if it grasps a common ideal and understanding of the Christian beliefs. Though the Church must be vigilant in maintaining the vital importance of genuine Biblicai conversion, it must also be increasingly effective in developing methods to take advantage of the paths that the Spirit of God may choose to open. It would appear that some churches in Sao Paulo have experienced rapid growth through people movements and that they should constitute themselves examples for the work of the Seventh-day Adventist Church as a whole in such an area.

The next principle is receptivity and resistance. Alcides Campolongo has developed an evangelistic method that requires research of the receptivity and resistance of the population prior to the realization of an evangelistic series. Through the years it was discovered that some suburban areas in Sao Paulo are less receptive than others. In the

$$
{ }^{1} \text { McGavran, Understanding Church Growth, p. } 303 .
$$


ministry of Jesus such a phenomenon was present too. On the one side of the Sea of Galilee Jesus met with a very high level of resistance, while on the other side he met with high receptivity. 1 The gospels also indicate that the disciples were to concentrate their work where there was strong receptivity. ${ }^{2}$ It seems that in the example of Jesus and the apostles there is no indication that the Church intentionally should neglect the immediately unresponsive and simply evangelize the responsive people, but that different strategies should be used to reach different kinds of hearers. Hence, social observations and statistics are important tools in identifying and predicting receptivity. A population, because of external factors, can move from resistance to receptivity and back to resistance again, and the Church must be vigilant to take advantage of these movements. McGavran states that "Winning the winnable while they are winnable seems sound procedure." 3 It seems that an adequate evangelistic strategy for Sao Paulo should take into consideration the receptivity and resistance of people living in different suburban areas of the city.

\section{Conclusion 2}

The laity as groups or as individuals rank the highest in soulwinning in the Sao Paulo metropolitan area. The different activities of the Church led by lay people comprise the most effective elements in the whole process of outreach.

\footnotetext{
1'Luke $8: 37,40$.

2 Matt $10: 14$.

${ }^{3}$ McGavran, Understanding Church Growth, p. 256.
} 
Recommendation. Donald McGavran points out that . . . any form of clericalism, any-limiting of evangelism to paid leaders, works heavily against church growth. In a receptive situation growth occurs in the church that mobilizes its laymen for continuous propagation of the Good News. 1

The SDA Church should use all its lay forces in fostering its strategy for future growth in Sao Paulo. There are about 200 hundred congregations and only forty paid pastors in the area. Therefore, most of the congregations must be led by laymen. The basis of the Adventist concept on this subject was expressed in 1883 by E. G. White: "Every man and woman who has a knowledge of the truth should be a co-worker with Christ. . . . He requires the lay-members to act as missionaries." 2 All members are ordained and commissioned in their baptism to ministry as co-laborers with Christ. ${ }^{3}$ Not only is this ideal set before the Church, but in the data given by this research it was verified that the Adventist Church growth is primarily the result of spontaneous witnessing of the believers at work, in the neighborhood, in the family-circle, and among friends.

When the Holy Spirit fell upon the believers on the day of Pentecost they "began to speak," 4 and a multitude came together as a result of their witness. Witnessing was the reason for the baptism of the Spirit. The Bible tells us that Peter and the apostles witnessed

1Donald McGavran, "Why Neglect Gospel-Ready Masses," Christianity Today 10. (April 29, 1966):769-71.

${ }^{2} E$. G. White, "The True Missionary Spirit," Review and Herald 60 (November 13, 1883): 433 .

${ }^{3}$ E. G. White, Medical Ministry, p. 138.

${ }^{4}$ Acts $2: 9$ (KJV). 
In Jerusalem and Judea, ${ }^{1}$ Phil in Samaria, ${ }^{2}$ Paul and Barnabas among the Gentiles and the membership being "scattered throughout the region, " ${ }^{3}$ preached the Word everywhere. ${ }^{4}$ The apostolic church correctly understood its responsibility of witnessing which resulted in a great harvest of souls.

The dynamic action of the members of the congregations in Sao Paulo is responsible for this unusual growth in the Adventist Church. Every Sunday evening all the congregations in Greater Sao Paulo are involved in evangelistic meetings. The members invite their friends and relatives, and using some audio-visual aids, elders and young people preach the Adventist doctrines. The Sunday evangelistic meetings are a vital element in the life of the congregations. This type of practice in the church opens weekly new opportunities for witnessing, and other missionary activities are naturally linked to it.

In this particular evangelistic program it is worthy to note that in this way evangelism is not a special program of the local congregation but the life of the church itself. McGavran and Arn press this very point, saying that:

Churches that have an evangelistic week once a year are not, as a rule, growing. churches but those that have regular evangelistic work going all the time, with reports at every board meeting, and charts in the pastor's study or boardroom showing the growth of the church--these are churches which are growing. 5

$$
\begin{array}{ll}
{ }^{1} \text { Acts } 3: 34 \text { (KJV). } & { }^{2} \text { Acts } 8: 4-8 \text { (KJV). } \\
{ }^{3} \text { Acts } 4: 1 \text { (KJV). } & { }^{4} \text { Mark } 16: 20 \text { (KJV). } \\
{ }^{5} \mathrm{D} . \text { McGavran and Win Arn, How to Grow a Church (Glendale, }
\end{array}
$$
Calif.: G/L Publications, 1973), p. 106. 
Therefore, evangelism has been for the growth of the Adventist churches in Sao Paulo what physical exercise is for the symmetrical growth of the human body.

There are many statements that indicate the importance of equipping, enabling, and educating the laymen for their mission. E. C. White speaks directly to this issue when she says:

Many suppose that the missionary spirit, the qualification for missionary work, is a special gift or endowment upon the ministers and a few members of the church and that all others are to be mere spectators. Never was there a greater mistake. Every true Christian will possess a missionary spirit, for to be a Christian is to be Christlike. No man lives to himself, and "if any man have not the Spirit of Christ, he is none of His." 1

She also instructs ministers to train each member "to improve his talents to the utmost." 2 There is no doubt that SDA pastors have a clear mandate to educate the people of God in redemptive development. These important aspects lead to the next conclusion of this research.

\section{Conclusion 3}

The SDA pastors cannot take the full responsibility of developing the churches in the explosive population of Greater Sao Paulo. It was reported by the new members that the pastors did not have a major influence in their decision to become members of the Adventist Church. This fact does not mean that the pastors should not be present in the church's affairs, but that they should act more as facilitators or "coaches" of the members.

${ }^{1}$ E. C. White, Welfare Ministry (Washington, D.C.: Review and Herald Publishing Association, 1952), pp. 55, 56.

${ }^{2}$ E. G. White, Education (Mountain View, Calif.: Pacific Press Publishing Association, 1903), p. 226. 
Recommendation. It seems appropriate to quote here just one of the many instances in which E. G. White emphasizes the important role that the pastor has to play in promoting the work of evangelization.

In laboring where there are already some in the faith, the minister should at the first try not so much to convert unbelievers as to train the church members for acceptable cooperation. Let him labor for them individually, endeavoring to arouse them to seek for a deeper experience themselves, and to work for others. When they are prepared to sustain the minister by their prayers and labors, greater success will attend his effort. 1

Laymen in Sao Paulo are engaged in many outreach activities and it seems that this has been a decisive factor in the growth of the Adventist Church there. It would appear that a very important task for the local pastor of the Adventist church is to develop a type of training school for the laity, preparing them to more effectively do their job. The program of such a school should include matters such as preaching, human relations, principles of leadership, urban ministry. Bible study methods, history of the Adventist Church, and doctrines of the church.

If the Adventists really believe that the laymen are going to have an important role to play in the last events of this world, they have to be prepared to take their responsibility, together with the paid ministers.

Wagner stresses this equiping role of the pastor: "The primary catalystic factor for growth in a local church is the pastor." 2 The

1E. G. White, Evangelism (Washington, D.C.: Review and Herald Publishing Association, 1946), pp. 110-111.

${ }^{2}$ Peter Wagner, Your Church Can Grow (Glendale, Calif.: Regal Books, 1976), p. 53 . 
pastor of a church must be the coordinator of activities that lead to a symmetrical growth. To develop in a proper way his role in a given congregation the pastor must have certain basic gifts as well as sufficient time. Research carried out by the administration of the East Sao Paulo Conference among the pastors and laymen indicated that the pastor should remain at least five years as leader of a church, ${ }^{1}$ because when the congregation is secure in the knowledge that their pastor will be with them for a long time they are willing to commit themselves to long-term plans for real growth. Church-growth studies suggest that it takes at least four years before real growth even begins. Wagner says, "The most productive years of a pastor usually begin only after the fourth to sixth year of the minister's tenure." ${ }^{2}$

\section{Conclusion 4}

About 70 percent of the members in the Sao Paulo metropolitan area attend small churches with about 150 communicants. Large churches in general work against the identification of the members by the leaders and much of the forces of the community are lost.

Recommendation. The rapid development of the city and the socio-economic situation of the people forced the Adventist Church to follow a strategy that became an important factor in her growth.

Referring to a strategy for this type of circumstance,

Paulo, Brasil.

${ }^{1}$ Unpublished paper of Associaçao Paulista Leste--1979--Sao

${ }^{2}$ Peter Wagner, Your Spiritual Gifts Can Help Your Church Grow (Glendale, Calif.: Regal Books, 1974), p. 163. 
McGavran and Arn write:

Many sections of a city today need a church which people can attend without driving great distances. One of the anomalies in the American scene is the large number of people who drive 5, 10, 15 miles to church.... In this situation, evangelistic potency is low. It's difficult to persuade the other families to drive across town to church. This weakness in the American scene needs to be eliminated in coming years. 1

The administration of the Adventist Church understood that it was impossible for the people living in those new districts to come to the central churches, because of their low income and the great number of members in each family.

Understanding such a reality, the Adventists in Sao Paulo decided that it would be far better to go where the people were living. rather than asking them to come where we had church buildings already. Following this policy the Sao Paulo Conference took advantage of the low price for which the land was being sold and bought approximately sixty lots in those new districts.

Soon some Adventist families living in those areas started to build very humble rooms as worship places. On Sunday evenings they were evangelistic halls, and during the week they were used as schools for the children.

Today, in each of those lots there is a good church building that concentrates the Adventists of the area which are responsible for a very active outreach activity.

According to the Statistical Report of the East Sao Paulo Conference in December, 1979, there were 35,000 members in the

\footnotetext{
${ }^{1}$ McGavran and Arn, p. 72.
} 
metropolitan area of Sao Paulo distributed in about 200 congregations. Considering that there are about nine large churches with more than one thousand members, the other 190 congregations have an average of 150 members.

In the book, How to Grow a Church, McGavran says . . . that new churches are a very common type of church. In fact, as you look at the church exploding and growing all around the world in country after country, you find multitudes of small churches. Just as full-grown men have all been little babies, so full-grown churches all began as little: churches. The normal thing for christians everywhere is to form new churches. They will be small; they will struggle, but remarkably few of them die. 1

This was precisely the strategy followed by the Adventist Church during the sixties in Sao Paulo, and doubtless it brought good results in growth and should be fostered in the days to come.

\section{Conclusion 5}

The outreach methods used by the Church in Sao Paulo are more effective when a personal relationship is established between church member and the prospective member. An essential ingredient in the most fruitful evangelistic factors is face-to-face relationship along lines of meaningful social involvement; for example, friends and relatives. The evangelistic agencies which have little or no personal contact with people influence a minimal number of new members to join the SDA Church in Sao Paulo.

Recommendation. Roy C. Stedman in his book, Body Life, says that the church is primarily and fundamentally a body designed to

1'lbid., p. 126. 
express through each individual member the life of an indwelling Lord and is equipped by the Holy Spirit with gifts designed to express that life. ${ }^{1}$

According to the Bible, the gifts of the Spirit were given to the church for edification in her responsibility for the gospel commission. Paul gives three reasons for which they are of particular need: "to equip the saints, for the work of the ministry, for building up the body of Christ." 2 The apostle makes it clear that the saints need to be well prepared for a special service as they enter the world to proclaim the gospel of Christ, and it implies that not only an isolated clergy receives gifts but that all converts are equipped and have to work for God.

In the Adventist Church in Sao Paulo this theological concept of Paul's is not discussed but it is accepted as the way of life for our congregations. But there is a danger to be avoided. As the economic and social level of some congregations rises, the outreach activities tend to be left to the paid ministers. The members are taken by the idea that they can substitute personal involvement for substantial offerings. According to the Bible, every member receives gifts of the Spirit and has a very important role to play in building up the body of Christ here on earth in full participation. 1972), p. 31 .

1'Ray C. Stedman, Body Life (Glendale, Calif.: Regal Books, ${ }^{2}$ Eph $4: 12$. 
Conclusion 6

The doctrines of the SDA Church with emphasis on obedience to God's law present a strong appeal to people in their decision to join the Adventist Church.

Recommendation. The SDA pastor should give more attention to biblical preaching, especially to placing greater emphasis on the Adventist doctrines concerning Jesus Christ. Since most of the new members were attracted to the Church by the doctrines, the pastors should prepare good sermons on doctrinal truths.

The Adventist Church is commissioned to make disciples; that is, call upon men to submit themselves to the claims of Christ to become His followers. It follows, therefore, that the Adventist preaching should naturally lead to decision. This implies that the Adventist preacher must press for a decision to accept all of the commandments of God, the full message for these times, to obedience of faith. Doubtless a clear presentation of the Word of God is a strong element in church growth.

\section{Conclusion 7}

The SDA Church has been developing its work mostly among the low-income families who live in the suburbs. The evangelistic strategy developed through the years appeals primarily to the nearly illiterate people. The middle-class apartment dwellers and the rich people of the upper class have only recently been systematically evangelized.

Recommendation. The SDA Church should give study to the possibility of developing a more effective outreach methodology to reach 
a greater variety of people. Special attention should be given to age, religious background, and socio-economic level of the population approached.

The SDA Church is making some work for special classes in Sao Paulo. In 1978 an evangelistic effort was started for the Jews. This plan proved to be effective and the Jewish Adventist community is growing under the pastoral leadership of Pastor Benoni. But there are many peculiar segments of the population waiting for the action of the Adventists. E. G. White indicates that working for special classes can be a strong element in fostering the growth of the church She speaks of "Large Harvest" ${ }^{1}$ among the special classes of the society. It seems that the special classes in Sao Paulo present a very meaningful challenge to the Adventist Church today.

\section{Conclusion 8}

The evangelistic method of giving Bible studies in homes with the help of filmstrip illustrations is reported by the new members as an effective element influencing people to make their decision to join the Adventists.

Recommendations. In the evangelistic planning of the SDA Church, a greater emphasis should be placed on utilizing the opportunities of personal contact centered in the home by fostering many small-group meetings (e.g., Bible study) in homes of various economic levels.

1E. G. White, Evangelism, p. 577. 
It is not some complex or elaborate plan that is needed. God will use simple means to finish His work: "God will use ways and means by which it will be seen that $\mathrm{He}$ is taking the reigns in His own hands. The workers will be surprised by the simple means that He will use to bring about and perfect His work of righteousness." 1

In relationship to this last statement; it is evident that one of the problems involved in getting lay-members to give Bible studies is the fact that most of them do not feel adequately trained to do so. Such training takes time, and often the enthusiasm that should be expended on doing the work is used up in long training sessions and in talking about how the work should be done. There is a decided need for a simple plan that ALL can use. Much is being said about the lack of interest or even consecration on the part of lay-members today because they do not seem to evince much interest in taking part in the various Bible study plans. Perhaps a significant portion of this attitude is due not so much to lack of interest as it is to the need for a method that can be readily handled without elaborate training, something in which the layman can have confidence because it does not demand Bible knowledge beyond his ability.

This more effective method must also be broad in its scope of usefulness rather than limited to must one effective method of operation. Not everyone has the time, the ability, or the inclination to use a tool in exactly the same way that everyone else does. It should be an instrument that lends itself not only to a variety of methods of use but

${ }^{1}$ E: G. White, Evangelism, p. 118. 
one through which the natural creativity of the lay-member can be exercised, thus making it a more personally rewarding and meaningful project for him.

In summary, Seventh-day. Adventists seem to recognize today that there is a definite need for a more effective method of personal evangelism which will:

1. Make it possible for every layman to participate if he chooses.

2. Involve personal contact in the homes of interested people-at least it will do so before the program is completed.

3. Be simple enough that it does not necessitate a complicated or prolonged training program.

4. Be effective enough that it will continue to build enthusiasm and fire the interest of those who are hesitant at first to adopt and use such a plan.

5. Be adaptable to a wide variety of usages and also be conducive to the exercise of personal creativity and participation on the part of those employing it.

These factors, as well as the needs revealed by this research, present a strong challenge to the development of a new approach to personal evangelism. It must meet the challenge presented by the current status of people of different levels in Sao Paulo. It must also be a plan that is interesting and useful to the Seventh-day Adventist laymen who will employ it. 


\section{Conclusion 9}

In the publishing ministry developed by the Seventh-day Adventists in Sao Paulo, the Jornal Adventista (Adventist Newspaper) is the most significant factor to help the Paulistans to make their decision for the Adventist faith.

Recommendation. In great cities like Sao Paulo the Adventists should publish newspapers to present to the people the peculiar doctrines of the Church. White indicates that the growth of the SDA Church is related to the use of publications. "More than one thousand will soon be converted in one day, most of whom will trace their first convictions to the reading of our publications." 1 Newspapers are a modern way of communication that easily catch the attention of people in large cities. In this research it was shown by the respondents that this resource proved to be effective in winning souls in Sao Paulo, and it is my conviction that the Adventist Newspaper is a helpful tool in propagating the Adventist beliefs in large cities with huge populations.

\section{Conclusion 10}

Television, among the mass media communication systems, proves to be the most effective means of reaching the population of Sao Paulo.

Recommendation. The SDA Church should gear its use of television to reach the middle and upper classes of the population,

'E. G. White, Evangelism, p. 693. 
since it is assumed that it is the best-known means of communication to reach this significant segment of society.

\section{Conclusion 11}

This research revealed that a systematic evaluation of the work done by the Seventh-day Adventist churches in Sao Paulo through the years is essential for the development of a church-growth strategy.

Recommendation. A survey instrument designed to periodically measure the growth of the church and to ascertain the relative effectiveness of the various methods used in soul-winning should be developed. The findings of such a study would help the Church to utilize the best method and approaches in developing its evangelistic strategy and to modify these methods and approaches from time to time as need arose.

The local congregation must be ready to evaluate that to which it has committed itself. Every planned activity should have an evaluation module built into it from its planning stage.

Vergil Gerber suggests that research is a means by which you can diagnose the health of your church or churches. ${ }^{1}$

It is very important for a pastor to have the ability to see behind the numbers of a statistical report the spiritual meaning, the hindrances or dynamics of a process. Only in this way is he capable of making a plan that can take advantage of the past experiences for a better result in the future. This function not only enhances

p. 45 .

${ }^{1}$ Vergil Gerber, God's Way to Keep a Church Going and Growing, 
accountability levels, but it permits modification to improve the planned performance of the local congregation. Evaluation will not perfect the local church, but it has a good chance of improving its achievements and growth potential. It serves to affirm the congregation for its attainments and to give possibility for more effective advancement.

\section{Recommendations for Further Study}

In the course of the study it was observed that several areas of the activities of the Seventh-day Adventist Church in Sao Paulo needed additional study. Observations supporting the need of further study are:

1. Most congregational activities and, in some cases, whole congregations, are led by lay leaders. But the question arises as to how well trained the lay leaders are to do their job properly. A survey could help the SDA Church in Sao Paulo to know in what specific areas there is a need to develop training programs for the layman.

2. The Afro-Brazilian religion, Umbanda, is a "people movement" in Sao Paulo. A study of its beliefs and practices could help the Church to develop a peculiar methodology to reach its adherents with the Adventist message.

3. The SDA Church in Sao Paulo has a high percentage of young people among its membership. A survey could help the denomination to make a self-evaluation of its educational work in the area and help to improve in areas that are weak. 


\section{General Conclusion}

It is true that most of the Adventists in Sao Paulo are not able to present theological reasons for the type of concept they have of the Church. They do not know so much theology but they believe in the Bible and the great commission of Jesus. For them the Seventh-day Adventist Church exists in their community as an agency of winning souls for Christ.

Doubtless the concept the members have about the Church and its purpose will determine the type of activities the congregation is going to have in the local area.

Jesus said to the disciples, "You are the salt" and "you are the light of the world." ${ }^{1}$ Both expressions are concerned with the responsibility of Christian ministry to the world whereby it might be saved from $\sin$ and its results.

Christ's goal for the Church is to establish a community of disciples who will carry the gospel of the Kingdom "to every nation and tribe and tongue and people." ${ }^{2}$ His goal for the Church is the ministry of love and concern for the perishing world.

White supports the idea of service as the main task of the Church. She says, "The Church is God's appointed agency for the salvation of men. It was organized for service, and its mission is to carry the gospel to the world." Further, she adds, "The Church is a repository of the riches of the grace of Christ; and through the Church will eventually be made manifest . . . the final and full display of the

\footnotetext{
${ }^{1}$ Matt 5:13-16 (RSV).

${ }^{2}$ Matt $28: 19,20$ (RSV).
} 
love of God." Therefore, those who claim to be His disciples must find "happiness in the happiness of those whom they help and bless." 1

The Adventist believers in Sao Paulo share the common idea that the only way of keeping a growing faith is through active witnessing. There is no divine and creative power in a church that does not witness of the love of Jesus to the sinful community in which she exists. This attitude has been proved to be more effective in nourishing the spiritual needs of the members than sitting around discussing theological issues as is the case in some of the Adventist churches in other parts of the world. There is a clear task for the Church in the urban world. There is a great evangelistic work to be accomplished in the Greater Sao Paulo area. The Seventh-day Adventist Church must put its trust in the Holy Spirit to break through the many hindrances to church growth and church planting. The Church must rely on this "blessed hope" to energize the administration, the pastors, and laity to give the method, the men, the money, and on the unction from above so that it may push forward in the propagation of the gospel in these times of unparalleled opportunity in Greater Sao Paulo.

${ }^{1} E$. G. White, Acts of the Apostles, pp. 9, 12. 


\section{APPENDIX A}

Copy of the original questionnaire and cover letter 


\title{
FACULDADE ADVENTISTA DE TEOLOGIA \\ Caixa Postal 7258 \\ 01000 - São Paulo
}

\begin{abstract}
Estudo sobre o crescimento da Igreja Adventista na area metropolitana de Sao Paulo
\end{abstract}

Querido irmão (a)

Cada ano Deus está acrescentando cerca de 3,000 membros à Sua Igreja em Săo Paulo.

Como tais pessoas entram em contato com a Verdade? Qual o programa da Igreja que tem sido o mais eficiente em ajudar as pessoas a se tornarem membros da Igreja?

Este questionário foi criado para ajudar-nos a obter respostas para tais perguntas.

É importante obter uma visăo clara destes elementos para que possamos dar direçāo certa à nossa programaçāo evangelística. Portanto, sua resposta ao questionário é de vital importância.

Solicitamos sua gentileza no sentido de preencher cuidadosamente o questionário, resppondendo-o da maneira mais honesta possível.

Năo é necessário colocar o nome e o endereço. Isto significa que as informaçōes serāo confidenciais.

Muito agradecido pelo seu grande auxílio.

Seu irmăo em Cristo 
Estudo do Crescimento da Igreja Adventista na Área Metropolitana de de Săo Paulo

\section{INSTRUCỖES}

Por gentileza circule o item que se aplica especialmente ao seu caso perticularmente, mas nunca mais do que três (3) a menos que isso seja indicado.

1. Quais săo as mais importantes razōes para você freqüentar a Igreja no dia de Sábado.

1. Para adorar a Deus

2. Para comungar com os irmăos

3. Para fortalecimento de minha fé

4. Para receber treinamento para o trabalho missionário

5. Para ouvir a voz de Deus

6. Para aprofundar meus conhecimentos das Escrituras

(Siga adiante para as páginas seguintes usando o procedimento indicado no exemplo acima) 
Estudo do Crescimento da Igreja Adventista na Area Metropolitana de Săo Paulo

INFORMACĂO DE FUNDO (Favor Circular cada item que se aplica a você)

1. Sexo

1. Masculino

2. Feminino

2. Idade

1. 10-14 anos

2. 15-19 anos

3. $20-29$ anos

4. $30-40$ anos

5. $41-70$ anos

3. Estado Civil

1. Casado

2. Separado

3. Viúvo e vive sosinho

4. Noivo

5. Sem Compromisso

4. Grau do Instrucăo Formal

1. Um pouco do primeiro grau

2. Primeiro grau completo

3. Um pouco do segundo grau

4. Segundo grau completo

5. Formaçăo Superior

5. Ocupaçăo

1. Estudante

2. Trabalho de escritório

3. Profissional empregado

4. Trabalha por conta própria - profissăo liberal

5. Empregado não especializado

6. Renda pessoal mensal

1. Menos de $\mathrm{Cr} \$ 5,000.00$

2. De 5 a $\mathrm{Cr} \$ 15,000.00$

3. De 15 a $\mathrm{Cr} \$ 25,000.00$

4. De 25 a Cr $\$ 50,000.00$

5. Mais de $\mathrm{Cr} \$ 50,000.00$

7. Tamanho da Comunidade de Origem

1. Menor de 5,000 habitantes

2. De 5 a 15,000 habitantes

3. De 15 a 25,000 habitantes

4. De 25 a 50,000 jabitantes

5. Mais de 50,000 habitantes

8. Regiāo Geográfica de origem

1. Norte

2. Centro-oeste

3. Nordeste

4. Sudeste

5. Sul 
Estudo do Crescimento da Igreja Adventista na Area Metropolitana de Săo Paulo

\section{ACERCA DE SUA EXPERIÊNCIA RELIGIOSA}

9. Influência da religiāo anterior

1. Acentuada

2. Moderada

3. Pouca

4. Nenhuma

10. Religiăo Anterior

1. Protestantismo tradicional

2. Pentecostal

3. Católica Romana

4. Espiritismo e Umbanda

5. Nenhuma

11. Condiçăo religiosa quando veio para a igreja Adventista

1. Muito religioso

2. Moderadamente

3. Religioso

4. Nao muito religioso

5. Nao religioso

12. De quem ouviu pela primeira vez falar de Adventista

1. Parentes

2. Pregador

3. Amigos

4. Curso de Correspondência

5. Rádio ou Televisāo

13. Que ajudou a você se decidir a se tornar membro da igreja Adventista

1. Um membro leigo

2. Instrutor Bíblico

3. Grupo de evangelismo de leigos

4. Pastor evangelista

5. Nenhum especialmente

EVANGELISMO PUBLICO

14. Quantas reuniōes frequentou

1. Uma

2. Poucas

3. Quase todas

4. Reunioes de várias séries

5. Algumas por curiosidade

15. Que tipo de reuniāo frequentou

1. Ligada À Voz da Profecia e Fé para Hoje

2. Evangelismo năo identificado

3. Evangelismo leigo

4. Reuniáo com filmes "Tesouros da Fé"

5. Voz de Mocidade 
Estudo do Crescimento da Igreja Adventista na Área Metropolitana de Săo Paulo

16. Convite que o levou a ir assistir a conferência

1. Volante

2. Pelo Jornal ou Radio

3. Convite perssoal de um parente

4. De um amigo vizinho

5. Outro tipo de ação missionária

RADIO, TELEVISÃO, TELEPAZ e JORNAIS

17. Antes de se tornar Adventista viu ou ouviu alguma vez falar dos Adventistas?

1. Sim

2. Nāo

18. Programa que assistiu antes de se tornar Adventista

1. Fé para Hoje

2. Voz da Profecia

3. Uma Luz no Caminho

4. Telepaz

5. Nenhum especialmente

TIPO DE ESTUDOS BÍBLICOS

19. Tipo de Estudos Bíblicos dos quais participou

1. Por Correspondência

2. Em casa

3. Escola Sabatina

4. De um Instrutor Bíblico

5. Classe Batismal

MINISTÉRIO DE PUBLICAÇŎES

20. Que publicaçăo ajudou você a se decidir para ser um Adventista

1. Atalaia, Mocidade, Vida e Saúde, Nosso Amiguinho

2. Folhetấo

3. Revista Adventista

4. Jornal Adventista

5. Outro

21. Livros que ajudaram a se decidir pela Igreja Adventista

1. O Desejado de Todas as Naçōes

2. O Conflito dos Séculos

3. Livros outros de Ellen G. White

4. Doutrinários

5. Saúde e outros 
Estudo Sobre o Crescimento da Igreja Adventista na Area Metropolitana de Săo Paulo

SUMÁRIO

22. Quais das seguintes pessoas ou agências mais influenciaram você a se unir a Igreja Adventista

1. Parente

2. Amigo, vizinho

3. Evangelismo público

4. Programas de Rádio e Televisão

5. Curso por Correspondência

23. Outros Fatores

1. Atividade dos leigos

2. Acolhimento social dos Adventistas

3. Servico comunitário

4. Obreiros Adventistas

Nenhum especialmente

24. O Que na Igreja mais o atraiu

1. Doutrinas

2. Amabilidade

3. Jesus Cristo

4. Os livros do Espírito de Profecia

5. Mensagem de Saúde

25. Por quais destas razōes você se tornou Adventista

1. Para encontrar a salvaçáo

2. Para guardar a Lei dos Dez Mandamentos

3. Por causa de amizade dos Adventistas

4. Por causa do Amor de Deus

5. Porque a Igreja Adventista é a verdadeira Igreja de Deus na Terra.

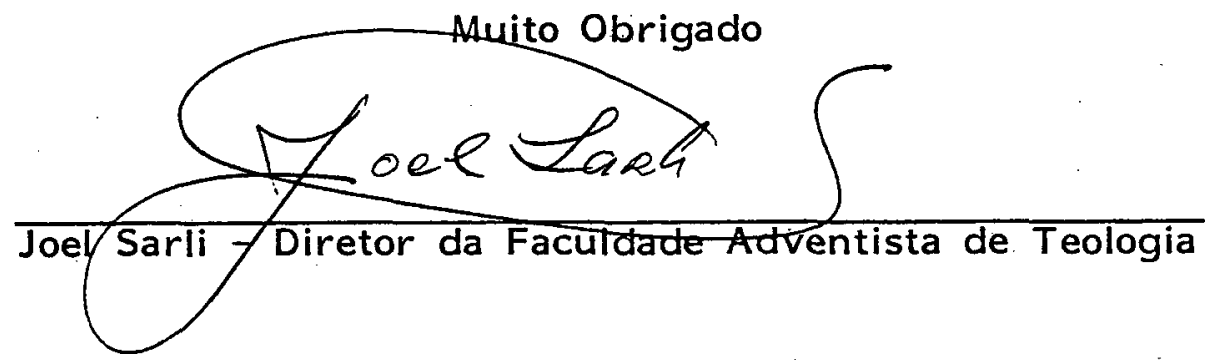




\section{APPENDIX B}

Map of São Paulo State--

East Micro-Regions 


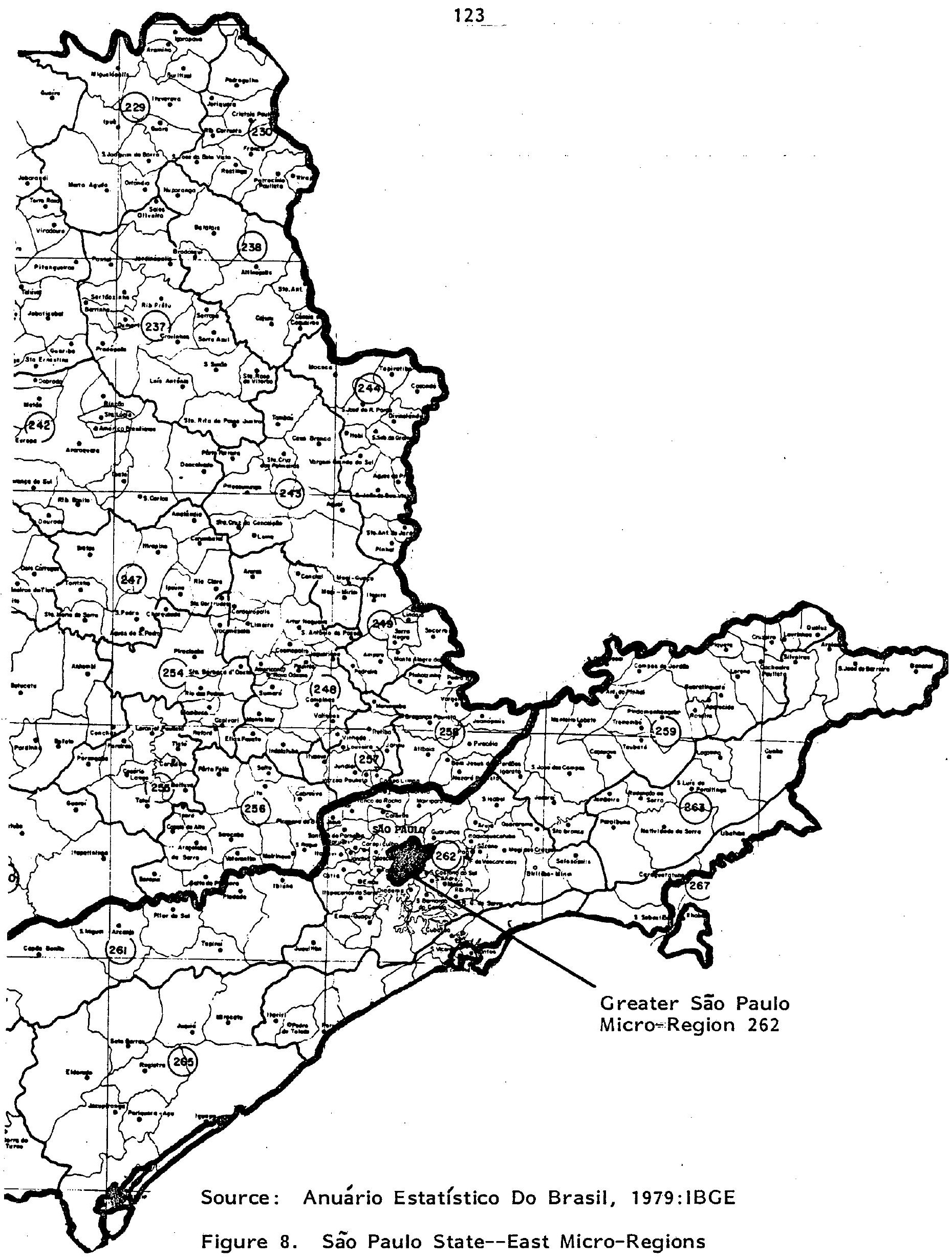




\section{SELECTED BIBLIOGRAPHY}

Anuário Estatístico do Brasil. Rio de Janeiro: Conselho Nacional de Estatística, 1960 e 1979.

Arroyo, Leonardo. São Paulo. São Paulo: Livraria Kosmos Editora, 1979.

Azevedo, Roberto C. A Voz da Profecia e a Conversão no Estado de São Paulo. São Paulo: Universidade de Sâo Paulo; Escola de Comunicaçöes e Arte, 1978.

Barley, W., and McEkvaney, W. Christ's Suburban Body. Nashville, Tenn.: Abingdon Press, 1979.

Bellah, Robert. "Religious Evolution." American Sociological Review, June 30, 1964.

Brewer, Elael, D.C. Protestant Parish. Atlanta: Communicative Arts Press, 1967.

Bultmann, R. "Pisteuo." In Theological Dictionary of the New Testament. G. Kittel, ed. Grand Rapids: Eerdmans, 1964-1976.

Camargo, Candido Procopio. "Essai de Typologie du Catholicisme Bresilien." Social Compass, 1967.

Carroll, Jackson W. Small Churches Are Beautiful. New York: Harper and Row Publishing Co., 1977.

Chaney, Charles. Design for Church Growth. Nashville, Tenn.: Broadman Press, 1977.

Comblin, Jose. Os Sinais dos Tempos. Recife: Duas Cidades Editora, 1968 .

Cook, Harold. Historic Patterns of Church Growth. Chicago: Moody Press, $1 \overline{971 .}$

Crabtree, A.R. História dos Batistas do Brasil. Rio de Janeiro: Casa Publicadora Batista, 1927.

Davis, J. Merle. How the Church Grows in Brazil. New York and London: Department of Social and Economic Research and Counsel, International Missionary Council, 1943. 
D'Epinay, L.C. El Refugio de Las Masas. Santiago, Chile: Editora del Pacifico, S. A., 1968.

Douglas, J. D. Let the Earth Hear His Voice. Minneapolis, Minn.: World Wide Publications, 1975.

Driggers, Carlisle. Models of Metropolitan Ministry. Nashville, Tenn.: Broadman Press, 1973.

Dubose, Francis M. How Churches Grow. Nashville, Tenn.: Broadman Press, 1978.

Eduardo, Otávio da Costa. "O Protestantismo em Sertão Novo, Comunidade Rústica do Interior do Pernambuco." Unpublished manuscript.

Enns, Arno W. Man, Milieu, and Mission in Argentina. Grand Rapids: Eerdmans Pub. Co., 1971.

Ferreira, Mulio de Andrade. História da Igreja Presbiteriana do Brasil. São Paulo: Casa Editora Presbiteriana, 1959.

Ferreira de Camargo, Cändido Procópio. Sao Paulo--Growth and Poverty. London: Bower Dean Press, 1978.

Francescon, Luis. Resumo de uma Ramificação da Obra de Deus, pelo Espirito Santo, no Século Atual. Chicago: Edição Pentecostal, 1958.

Fray, Herold, Jr. Conflict and Change in the Church. Boston: Pilgrim Press, 1952.

Froom, LeRoy E. Movement of Destiny. Washington, D.C.: Review and Herald Pub. Assn., 1971.

Gates, Charles W. Industrialization: Brazil's Catalyst for Church Growth. South Pasadena, Calif.: William Carey Library, 1972.

Gerber, Vergil. God's Way to Keep a Church Going and Growing. South Pasadena, Calif.: William Carey Library, 1973.

Gillin, John L. "A Contribution to the Sociology of Sects." American Journal of Sociology 16 (1910).

Gonçalves, Antonio de Campos. "Evangelism in Brazil Today." The International Review of Missions 48 (1959).

Greenway, Roger S. Apostles to the City. Grand Rapids: Baker Book House, 1978. 
1979.

- Discipling the City. Grand Rapids: Baker Book House,

- Guidelines for Church Planting. Grand Rapids: Baker Book House, 1978.

- An Urban Strategy for Latin America. Grand Rapids: Baker Book House, 1973.

- A World to Win. Grand Rapids: Baker Book House, 1975.

Gregory, Alfonso. A Igreja no Brasil. Rio de Janeiro: Federação Internacional dos Institutos Católicos, 1965.

Heppenstall, Edward. Salvation Unlimited. Washington, D.C.: Review and Herald Pub. Assn., 1974.

Hoelzle, Emilio." "Missão Paulista." Revista Mensal. São Bernardo do Campo: Casa Publicadora Brasileira, 1980.

Hoge, R. Dean, and Roozen, D.A., eds. Understanding Church Growth and Decline 1950-1978. New York: Pilgrim Press, 1979.

Hogue, C.D. I Want my Church to Grow. Nashville, Tenn.: Broadman Press, 1977.

Hoover, W.C. Historia del Avivamiento Pentecostal en Chile: Valparaiso: Imprenta Excelsior, 1948.

Houtart, Francois. "Les Effects du Changement Social Sur la Religion Catholique en Amerique Latine." Archives de Sociologie des Religions 12 (1961).

Hutchinson, Beltram. Mobilidade e Trabalho. Rio de Janeiro: Centro de Pesquisas Educacionais. Ministério de Educação e Cultura, 1960.

Hyles, Jack. How to Boost Your Church Attendance. Grand Rapids : Zondervan Pub. House, 1958.

IBGE (Instituto Brasileiro de Geografia e Estatística). Recenseamento Geral do Brasil, 1979.

Jesus, M. C. de. Quarto de Despejo: Diário de Uma Favelada. São

Paulo: Livraria Francisco Alves, 1960.

Johnson, Merle Allison. How to Be Happy in the New Electric Church. Nashville, Tenn.: Abingdon Press, 1970.

Jones, Ezra, E. What's Ahead for Old First Church? New York: Harper and Row Publishers, 1974. 
Kardec, Allan. O Que é o Espiritismo? São Paulo: Empresa Editora. "O Pensamento," 1967.

Kidder, D.P., and Fletcher, J.C. Brazil and the Brazilians.

Philadelphia: Child and Peterson, 1858.

Kloetzli, Walter. Challenge and Response in the City. Rock Island, III. : Augustana Press, 1962. 1958 .

Lawson, E. LeRoy, and Yamamori, T. Church Growth Everybody's Business. Cincinnati, Ohio: A Division of Standard Publishing, 1973 .

Lee, Robert. The Church and the Exploding Metropolis. Richmond, Virginia: John Knox Press, 1967. 1962 .

- Cities and Churches. Philadelphia: Westminster Press,

Leiffer, Murray. City and the Church Transition. Chicago: Willet, Clark and Company, 1968.

- The Effective City Church. New York: Abingdon Press, 1961.

Leite, Antonio Attico de Sousa. Fanatismo Religioso, Memória sobre - Reino Encantado na Comarca de Villa Bella. Juiz de Fora: Brasil, 1898.

Lenski, Gerhard. "Religious Pluralism in Theoretical Perspective." International Yearbook for the Sociology of Religion.

Volume I, 1965.

Leonard, Emile. L'illuminisme dans un Constitution Recent. Paris: Presses Universitaires, 1953.

Ligget, Thomas. The Role of the Missionary in Latin America New York: Committee on Cooperation in Latin America, NCCC, 1963.

- The Call of the Missionary in Latin America Today. New York: Committee on Cooperation in Latin America, NCCC, 1963.

Lueke, Richard Henry. Preaching. Chicago: Urban Training Center Press, 1972. 
McGavran, Donald A. Ethnic Realities and the Church. Pasadena,

Calif.: William Carey Library, 1979. 1955.

- The Bridges of God. New York: A World Dominion Press,

- Understanding Church Growth. Grand Rapids: W. M.

Eerdmans, 1970 .

. "Why Neglect Gospel-Ready Masses?" Christianity Today

10 (April 29, 1966).

McGavran, Donald, and Arn, W. How to Grow a Church. Glendale,

Calif.: G/L Publications, 1974.

McManis, Lester W. Handbook on Christian Education in the Inner City. New York: Seabury Press, 1966.

McNeil, Jesse. Mission in Metropolis. Grand Rapids: Eerdmans Pub. Co., $196 \overline{5 .}$

McQuilking, J. Robertson. Measuring the Church Growth Movement. Chicago: Moody Press, 1974.

Madsen, Paulo. The Small Church Valid, Vital, Victorious. Valley Forge, Pa.: Judson Press, 1975.

Manual for Ministers. Washington, D.C.: General Conference of the Seventh-day Adventists, 1977.

Manual Presbiteriano. São Paulo: Casa Editora Presbiteriana, 1960.

Marikaua, Titsuo. Biblical Dimension of Church Growth. Valley Forge, Pa.: Judson Press, 1979.

Melvin, Herold, Jr. Religion in Brazil: A Sociological Approach to Religion. Boston: Harvard University, 1971.

Mesquita, Antonio N. A História dos Batistas do Brasil. Rio de Janeiro: Casa Publicadora Batista, 1940.

Milliet, Sergio. Roteiro do Cafe. Sao Paulo: Coleçáo Departamento de Cultura, Volume XXV, 1939.

Ministry: Washington, D.C.: Review and Herald Pub. Assn., June 1980 .

Mission Focus. Elkhart, Ind.: Mennonite Board of Missions, September 1980. 
Monsma, Timothy. An Urban Strategy for Africa. Pasadena, Calif.: William Carey Library, 1979.

Moothous, Carl. New Churches. Gary, Ind.: Carl W. Moothous, 1975.

Mylander, Charles. Secrets for Growing Churches. San Francisco, Calif.: Harper \& Row, Publishers, 1979.

Neufeld, Don F., ed. Seventh-day Adventist Encyclopedia. Washington, D.C.: Review and Herald Pub. Assn., 1976.

Nevius, John L. Planting and Development of Missionary Churches. Nutley, N.J.: Presbyterian and Reformed Pub. Co., 1978.

Nida, Eugene. "The Relationships of Social Structure to the Problems of Evangelism in Latin America." Practical Anthropology.

Vol. 5, No. 3, 1958.

. "Culture and Church Growth." In Church Growth and Christian Mission. Donald McGavran, ed. New York: Harper and Row Publishers, 1965.

Niebuhr, H. Richard. The Social Sources of Denominationalism. New York: Henry Holt and Co., 1929.

Noyce, Gaylord B. The Responsible Suburban Church. Philadelphia: Westminster Press, 1970.

- Survival and Mission for the City Church. Philadelphia: Westminster Press, 1975.

O Guia de São Paulo. São Paulo: Edição Quatro Rodas, 1980.

Oliveira, Vianna. Populacões Meridionais do Brasil. Volume I. Rio de Janeiro: Livraria José Olympio, 1952.

Olson, Gilbert. Church Growth in Sierra Leona. Grand Rapids: Eerdmans Pub. Co., 1969.

Oosterwal, Gottfried. Patterns of SDA Church Growth in America. Berrien Springs, Mich.: Andrews University Press, 1976.

Oosterwal, G. et al. Servants for Christ: The Adventist Church Facing the 80s. Edited by Robert E. Firth. Berrien Springs, Mich.: Andrews University Press, 1980.

Palmer, Marjorie, and Bernard, Alvin. How Churches Grow. Minneapolis, Mn.: Bethany Fellowship, Inc., 1976. 
Parker, B. Sidney. The Problem of the Church Drop-Out. New York: Vantage Press, 1971.

Pierson, Donald. Cruz das Almas: A Brazilian Village. Washington, D.C.: Smithsonian Institute of Social Anthropology, Publication Nos. 12, U.S. Government Printing Office, 1951. - Negroes in Brazil. Chicago: University Press, 1942.

Pope, Liston. Millhands and Preachers. New Haven, Conn.: Yale University Press, 1965.

Read, William R. New Patterns of Church Growth in Brazil. Grand Rapids: Eerdmans Pub. Assn., 1965.

Read, William R., and Ineson F.A. Brazil-1980. Monrovia, Calif.: MARC, 1973.

Read, William; Monterroso, $\mathrm{V}_{\text {.; }}$ and Johnson, H. O Crescimento da Igreja na América Latina. São Paulo: Editora Mundo Cristão, 1969.

Relatório Estatístico da Congregacão Cristã do Brasil. São Paulo: Congregaçăo Cristã do Brasil, 1978.

Relatório Estatístico da Associação Paulista Leste, 1979.

Revista Mensal. Săo Paulo: Casa Publicadora Brasileira, 1908.

Ribeiro, Favila. "O Latifúndio na Conjuntura Urbana." Fortaleza: manuscrito.

Rocha, Pombo. Historia de São Paulo. São Paulo: Companhia Melhoramentos de Sâo Paulo; 1918.

Rossi, Agnelo. Diretório Protestante no Brasil. Campinas: Tipografia Paulista, 1938.

Santos, Floriano Xavier dos. Relatório da Associação Paulista. São Carlos, 1977.

Schaller, E. Lyle: Assimilating New Members. Nashville: Abingdon Press, 1978.

- Planning for Protestantism in Urban America. New York: Abing don Press, 1965.

SEAD. Central de Dados e Referências do Governo do Estado de São Paulo. São Paulo: Secretaria do Planejamento, 1980 . 
Serviço de Estatística Demográfica, Moral e Politica. Estatística do Culto Protestante no Brasil. Rio de Janeiro: Servico Gráfico do Instituto Brasileiro de Geografia e História, 1959, 1960.

Seventh-day Adventist Church Manual. Washington, D.C.: General Conference of Seventh-day Adventists, 1976.

Seventh-day Adventist Yearbook. Washington, D.C.: Review and Herald Pub. Assn., 1980.

Shippey, Frederick: Protestantism in Suburban Life. New York: Abingdon Press, 1964.

Singer, P. A Economia Politica da Urbanizaçăo. São Paulo: Editora Brasiliense, 1973 .

Smith, Ebbie C. A Manual for Church Growth Surveys. Pasadena, Calif: : William Carey Library, 1976.

Smith, Lynn. Brazil : People and Institutions. Baton Rouge: Louisiana State University Press, 1963.

Snyder, Howard A. The Problem of Wine Skins. Downers Grove, III.: Inter-Varsity Press, 1975.

Stedman, Ray G. Body Life. Glendale, Calif.: Regal Books, 1972.

Todd, John. Moral Influences, Dangers and Duties Concerned with Great Cities. Philadelphia: Smith and Peck, 1941.

Torney, George. Toward Creative Urban Strategy. Waco, Texas: Word Books Publishers, 1964.

Towns, Elmer. America's Fastest Growing Churches. Nashville, Tenn.: Impact Books, 1972.

Wagner, Peter C. Your Church Can Be Healthy. Nashville, Tenn.: Abingdon, 1979 .

- Your Church Can Grow. Glendale, Calif.: Division of $\mathrm{G} / \mathrm{L}$ Publications, 1976.

- Your Spiritual Gifts Can Help Your Church Grow.

Glendale, Calif.: Regal Books, 1974.

Webber, George W. The Congregation in Mission. New York: Abingdon Press, 1964.

Weld; W., and McGavran, D.A. Principios del Crecimiento de la Iglesia. Chicago: Editorial Moody, 1970. 
Werning, Waldo. Vision and Strategy for Church Growth. Chicago: Moody Press, 1977.

White, Ellen G. Acts of the Apostles. Mountain View, Calif.: Pacific Press Pub. Assn., 1950.

- Education. Mountain View, Calif.: Pacific Press Pub. Assn. : 1952 .

- Evangelism. Washington, D.C.: Review and Herald Pub. Assn., 1946.

- Medical Ministry. Mountain View, Calif.: Pacific Press Pub. Assn., 1910.

- The Ministry of Healing. Mountain View, Calif.: Pacific Press Pub. Assn., 1938.

. "The True Missionary Spirit." Review and Herald 60 (Nov. 13, 1883).

- Testimonies for the Church. 9 vols. Mountain View, Calif.: Pacific Press Pub. Assn., 1943.

- Welfare Ministry. Washington, D.C.: Review and Herald Pub. Assn., 1952.

Winter, Gibson. The New Creation as Metropolis. New York: Macmillan Co., 1963.

Willems, Emilio. Followers of the New Faith. Nashville; Tenn.: Vanderbilt University Press, 1967.

- "Religious Mass Movements and Social Changes in Brazil." International Review of Missions 42 (1965).

Yamamori, Tetsunao, and Lawson, E. LeRoy. Introducing Church Growth. Cincinnati, Ohio: A Division of Standard Publishing, 1975.

Younger, George D. The Church and the Urban Renewal. Philadelphia: J. D. Lippincott Co., 1966.

Ziegenhal, Walter. Urban Church in Transition. New York: Pilgrim Press, 1978. 


\section{VITA}

Name:

Date and place of birth:

Secondary, undergraduate and graduate school attended:

Degrees

awarded:

Professional experience:
Joel Sarli

November 25, 1936; Jahu,..Sao Paulo, Brazil

1950-1952 Colégio Adventista Brasileiro 1953-1955 Ginásio Adventista Campineiro 1956-1958 Colégio Adventista Brasileiro 1959-1962 Faculdade Adventista de Teologia 1973-1976 Andrews University, SDA Theological Seminary

Bachelor of Theology, Faculdade Adventista Teologia

Master of Divinity, Andrews University

D. Min., Andrews University

1962-1965 Baritone in the Voice of Prophecy Brazilian male quartet

1966-1968 Pastor-evangelist, Parana Conference

1968-1971 Evangelist, South Brazil Union

1971-1973 Evangelist, South American Division

1973-1979 Teacher of theology in Brazil College

$1980-$
Dean of the School of Theology in South Brazil. 